\title{
صورة المرأة اليهودية في مسرح علي أحمد باكثير
}

\section{د/ نجية أحمد قدري عبد الحميد}

(مدرس المسرح بكلية التربية النوعية - جامعة المنصورة الميلة)

\section{ملخص البحث}

مشكلة البحث: تتبلور مشكلة البحث في الإجابة علي السؤال التالي: ما هي صورة المرأة

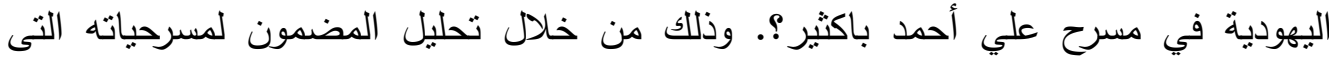
تتاولت هذه الإشكالية؟. أهمية البحث: يعتبر البحث في شخصية المرأة اليهودية من البحوث الهامة للعالم العربي؛ حيث إنها تكثف له طبيعة هذه الثخصبة التئي التي تُعد العدو الأول للعالم العربي.

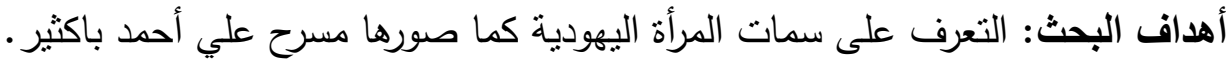
نوع البحث ومنهجه: يعد البحث من البحوث الوصفية في التى تحليل المحتوي طريقة اختيار العينة: اختارت الباحثة بطريقة عمدية النصوص التي نتاولت المرأة اليهودية

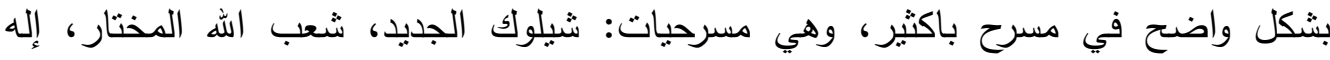
إسرائيل، والتوراة الضائعة.

$$
\text { نتائج البحث: }
$$

- وفق علي أحمد باكثير في رسم صورة المرأة اليهودية بشكل يقترب إلي الواقع، وبما يتفق مع أبعادها المادية والاجتماعية والنفسية. - المرأة اليهودية في مسرح باكثير جميلة الثكل، وتتمتع بالوجه الحسن والقية القوام الفتان. فهي امرأة شقراء ممشوقة القوام، ناضجة الأنوثة، كلها إغراء وفتتة. كما تتمتع بالذكاء.

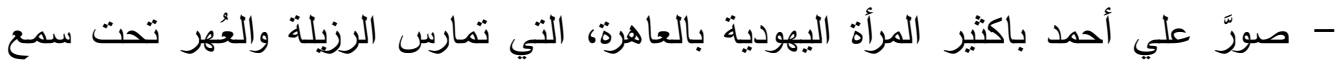

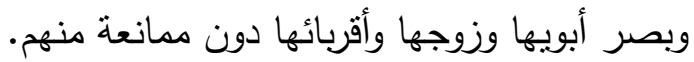

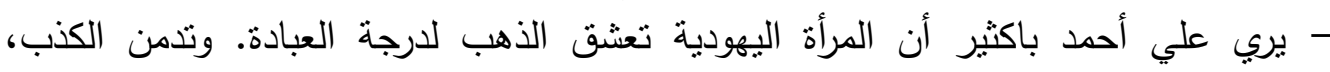
وخائنة، ومهملة، وشيطانة، وذكية، وكافرة، وغيورة، ومخادعة، ومحتالة،ورعديمة الأخلاق، وتلعب دورًا فعالًا داخل الجماعات الوظيفية الإسرائيلية. 


\section{المجلة العلمية لكلية التربية النوعية}

\section{Research Summary}

The problem of research: The problem of research is the answer to the question: What is the image of the Jewish woman in the theater of Ali Ahmed Bakthir? Through analyzing the content of his plays that dealt with this problem

The importance of research: The research on the personality of Jewish women is an important research of the Arab world, as it reveals to him the nature of this personality, which is the first enemy of the Arab world

The objectives of the research: To identify the characteristics of Jewish women as portrayed by Ali Ahmed Bakthir Theater

Research type and methodology: Research is a descriptive research in content analysis

Method of selection of the sample: The researcher deliberately chose the texts that dealt with Jewish women clearly in the Bakthir theater, namely: the new Shiluk, the chosen people of God, the God of Israel, and the lost Torah research results

- According to Ahmed Bakthir in drawing the image of Jewish women in a manner close to reality, and in accordance with their physical, social and psychological dimensions.

- The Jewish woman in the theater of Bakthir beautiful shape, and enjoy the good face and strong textures. She is a blonde woman with lustrous textures, mature femininity, all seductive and seductive. She also has intelligence.

- Ali Ahmed Bakthir's picture of the Jewish woman in a prostitute, who practices risilla and mute under the eyes and eyes of her parents, her husband and her relatives without any objection from them

- Ali Ahmed Bakthir sees that Jewish women love gold to the point of worship. Lying, deceitful, negligent, demonic, intelligent, infidel, jealous, deceitful, fraudulent, immoral, and plays an active role within Israeli functional groups. 
يزعم اليهود أنهم شعب الله المختار ، وأنهم من جنس سامي، وأنهم أفضل أنواع البشرية علي

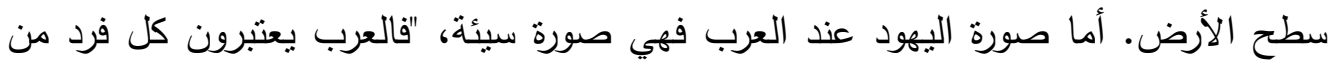

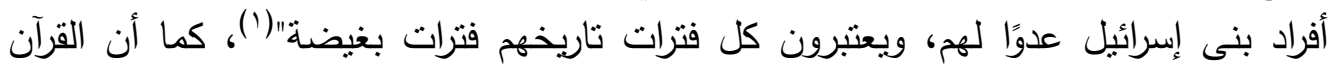

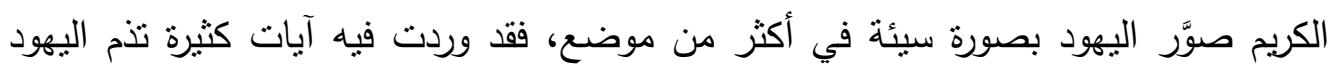

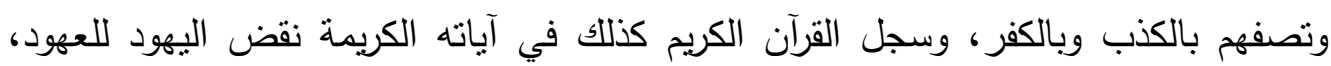

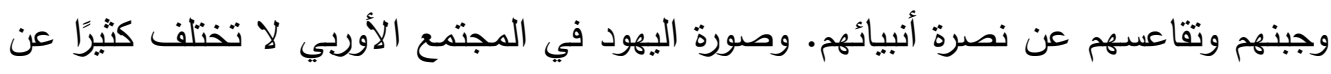

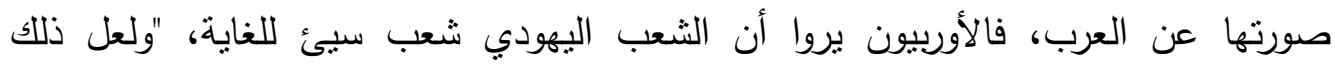
من الأسباب التى أدت إلى كثثير من التوترات الإجتماعية التى حدثت التى بين التئ اليهود

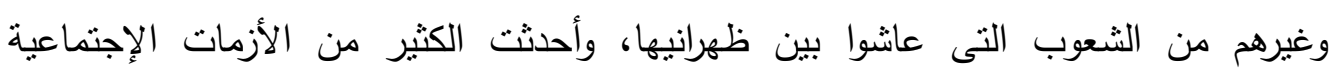
والحواجز النفسية"(r). وقد عاش اليهود في كل بقاع العالم كمواطنين عاديين، مثلهم مثل أي مواطن في الدولة التي

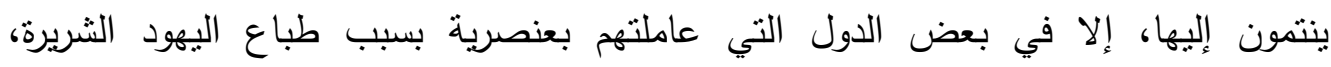

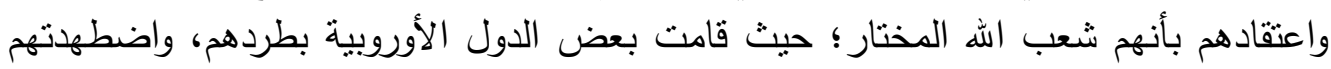

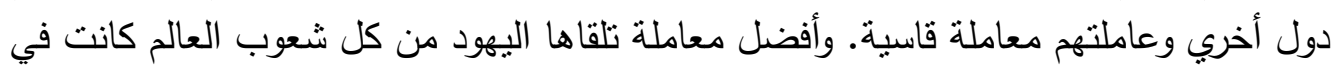

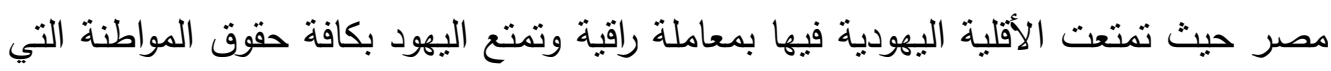

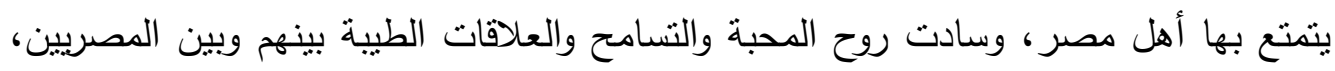

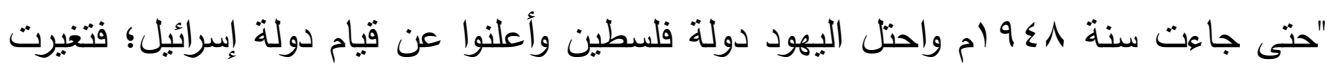

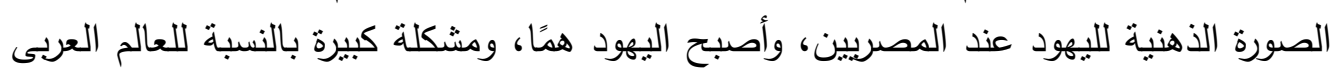

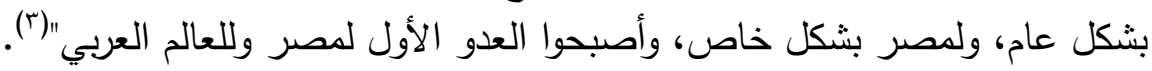

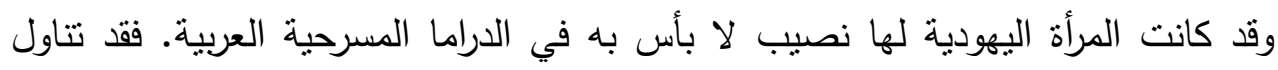

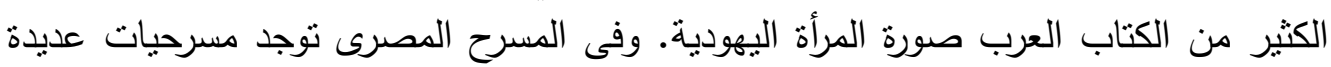

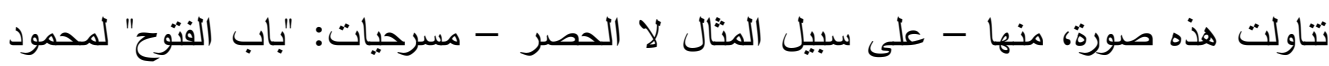

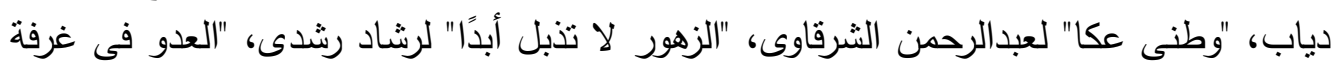

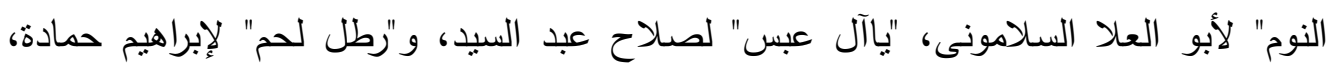

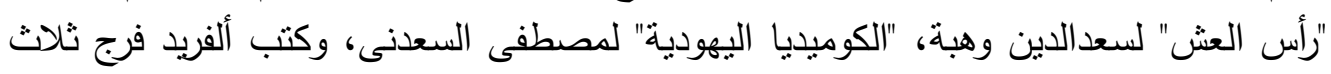

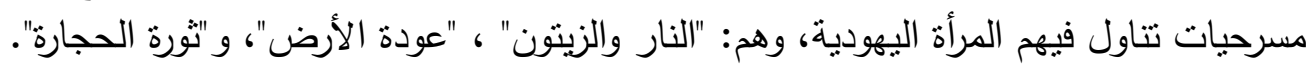

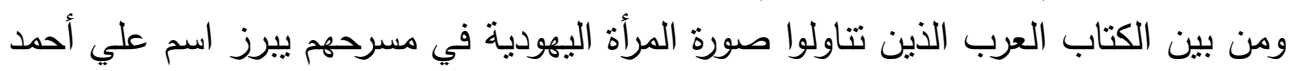

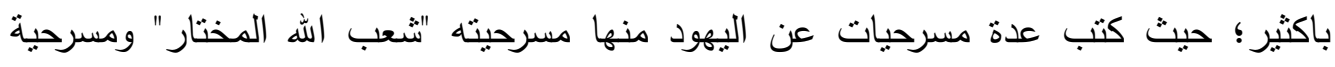

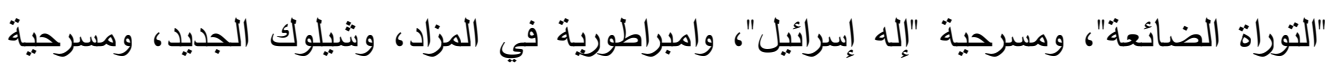

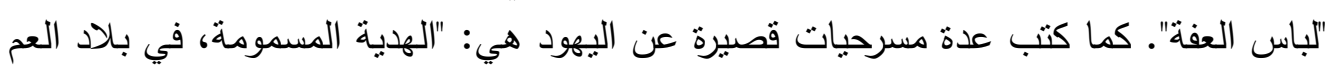




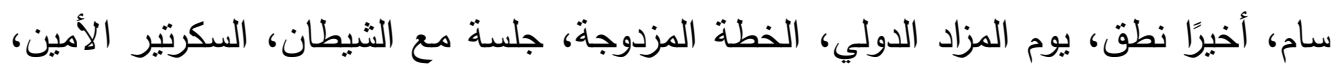

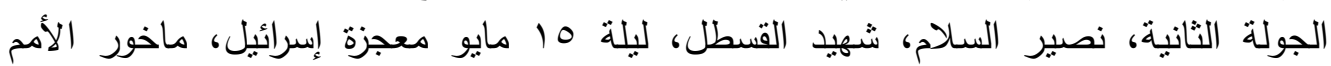

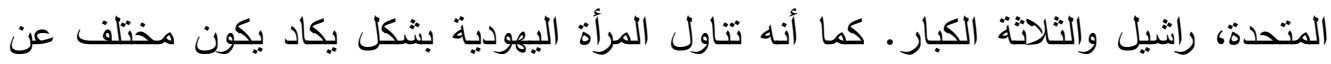

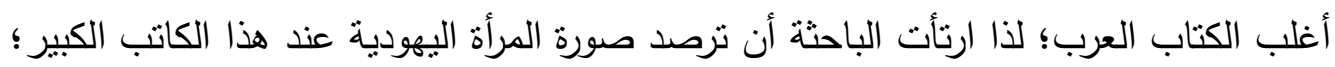

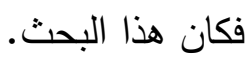

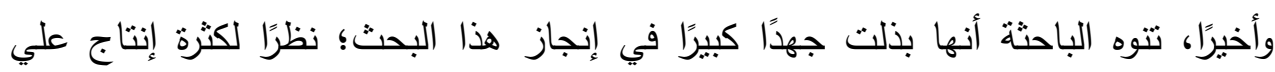

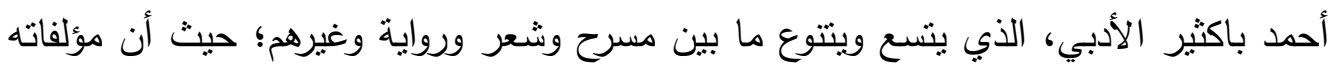

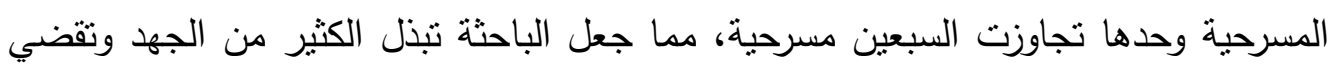

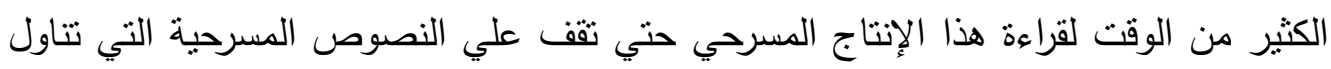

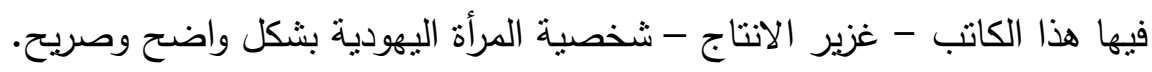

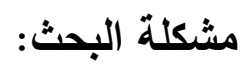

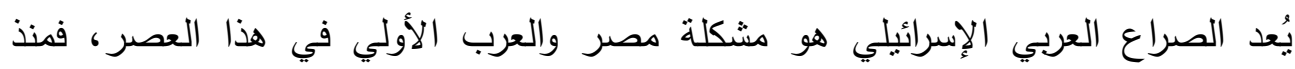

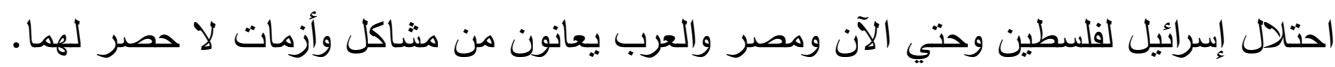

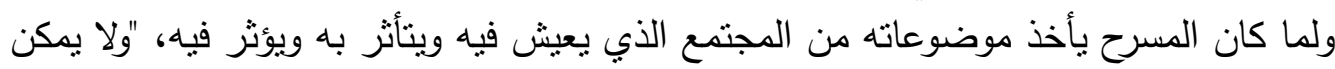

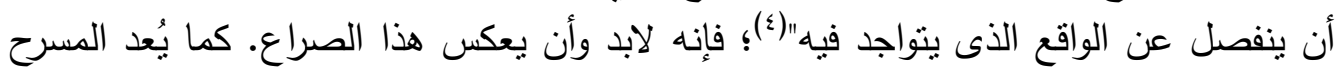

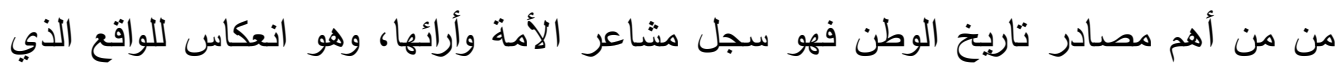

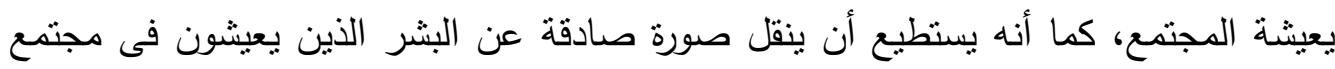

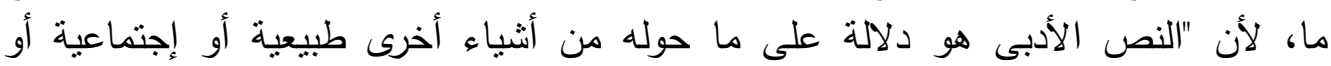

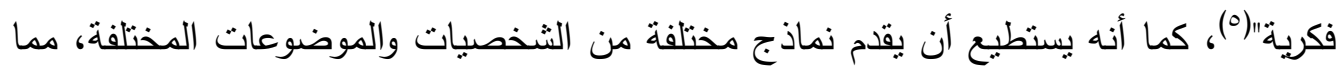

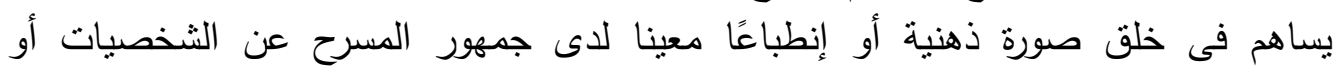

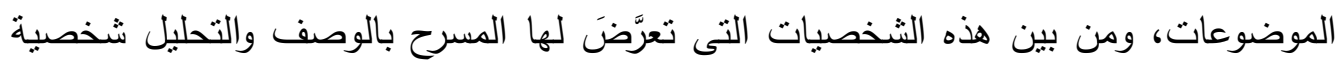

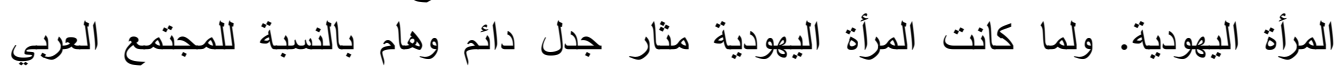
والإسلامي بشكل عام والمصري بشكل خاص؛ وخاصة أن الصورة الذهنية للمرأة اليهودية

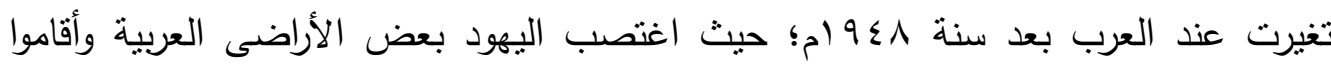

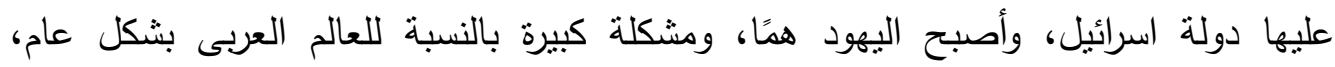

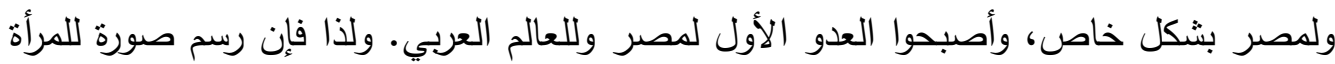

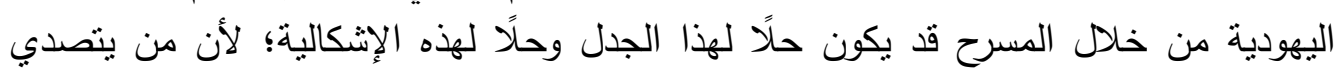

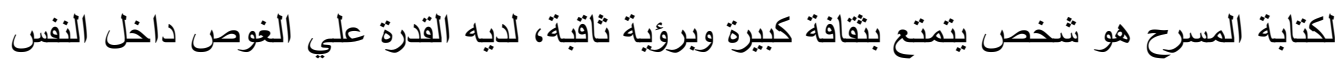

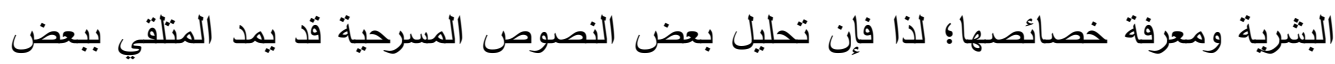

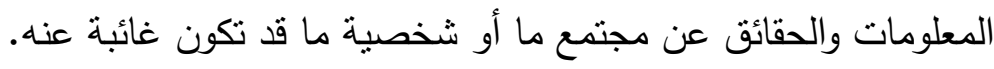


ومن بين كتاب المسرح الذين كتبوا عن الثخصية اليهودية بشكل غزير هو الكاتب علي

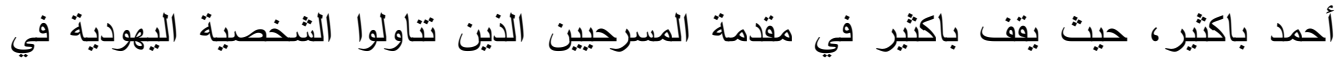

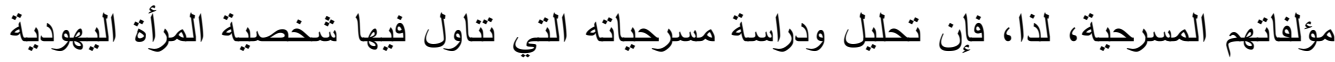

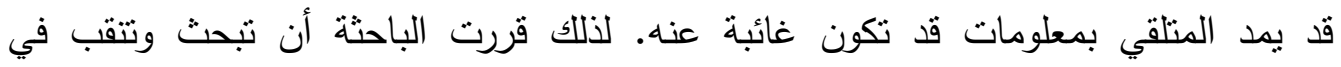

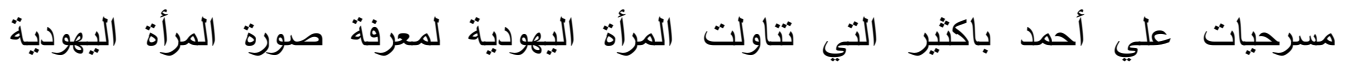
في مسرحه.

وبناءا عليه فقد تبلورت مشكلة هذا البحث في السؤال الرئيس التالي: ما هي صورة المرأة

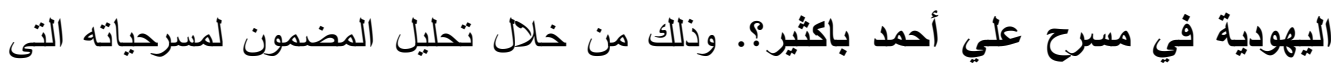
تتاولت هذه الإشكالية؟. تساؤلات البحث : بطرح هذا البحث عدة تساؤلات فرعية أهمها:

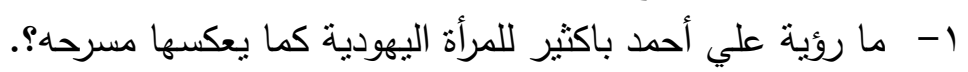

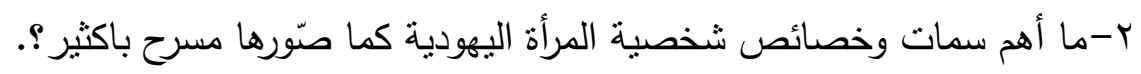
أهمبة البحث: أهم أبثات

1 - هذا البحث يتتاول صورة المرأة اليهودية من منظور كاتب عربي مهنم في مؤلفاته بقضية

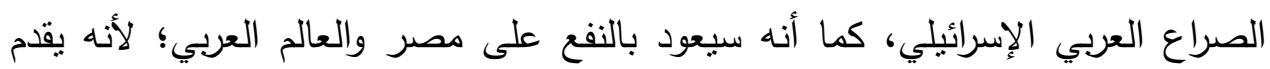

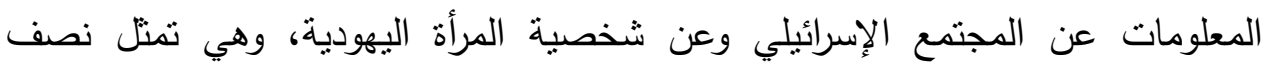

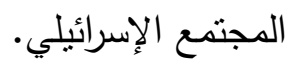

r - يعتبر البحث في الثخصية اليهودية، وخاصة اليهودية الإسرائيلية من البحوث الهامة للعالم

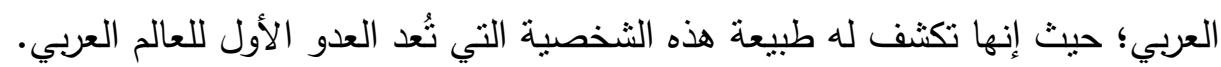

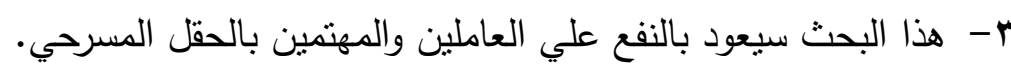

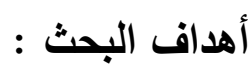

1-التعرف على سمات وخصائص المرأة اليهودية كما صورها مسرح علي أحمد باكثير .

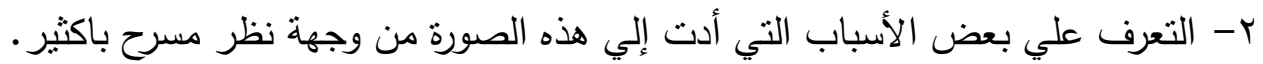

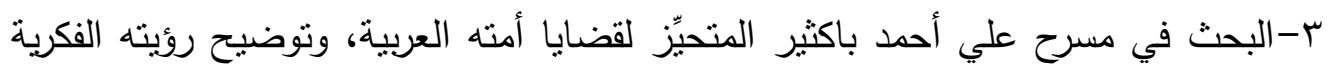
والسياسية والفنية والإنسانية تجاه المرأة اليهودية.

$$
\text { مجتمع البحث: }
$$

جميع مسرحيات علي أحمد باكثير التي تتاولت المرأة اليهودية. حدود البحث: جيع: منرح

جميع النصوص التي قام بتأليفها علي أحمد باكثير والتي تتاول فيها صورة المرأة اليهودية بشكل واضح. 
نوع البحث ومنهجه:

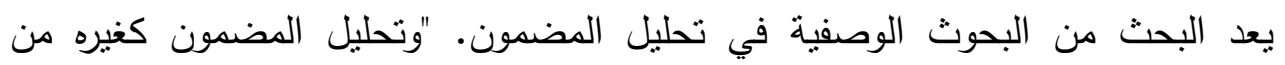

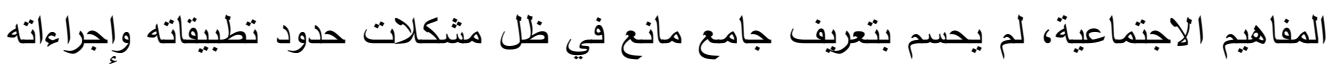

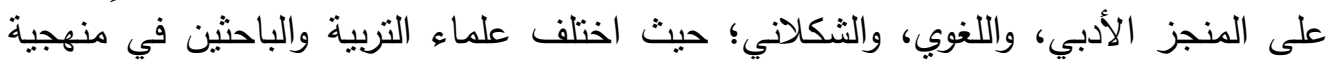

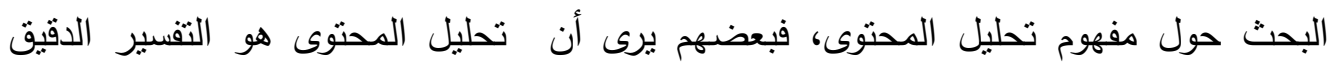

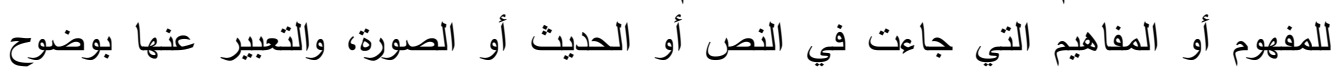

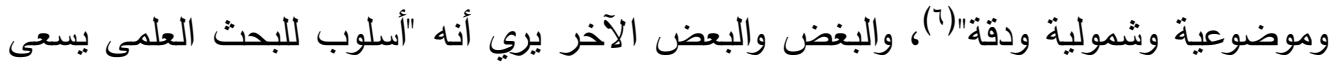

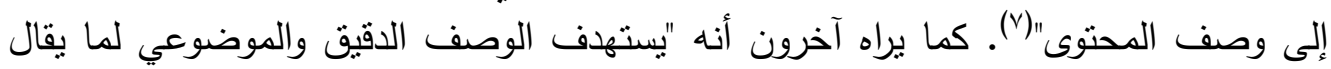

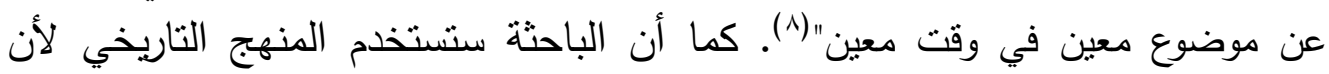

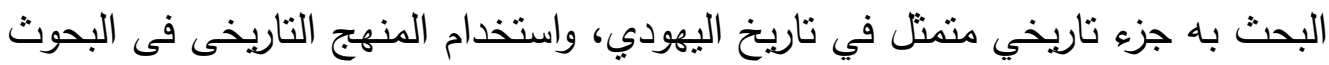

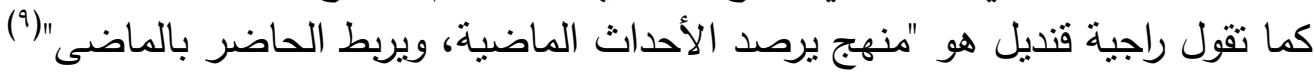

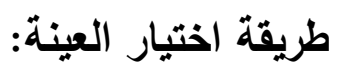

قرأت الباحثة جميع النصوص المستة المرحية التي كتبها علي أحمد باكثير، واختارت منها -

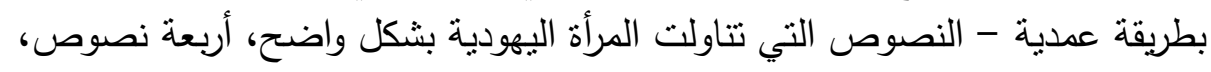

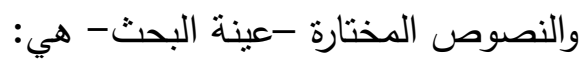

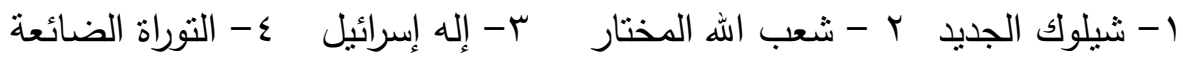
مصطلحات البحث: الثخصية : هى تتظيم داخل الفرد له قدر من الثبات والدوام لمجموعة من الوظائف أو السمات

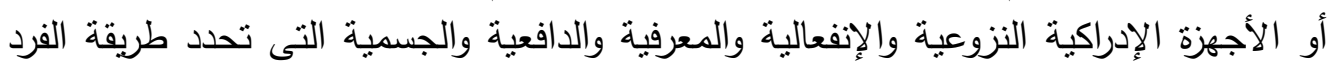

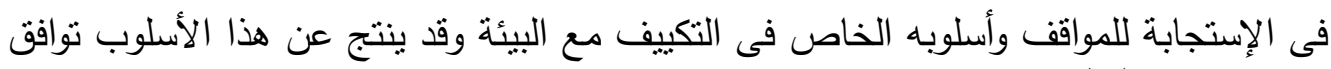

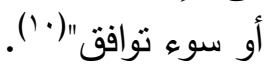

إسرائيل :هى كلمة "تشير إلى الدولة الصهيونية، والإسرائيليون هم سكانها"(' ").

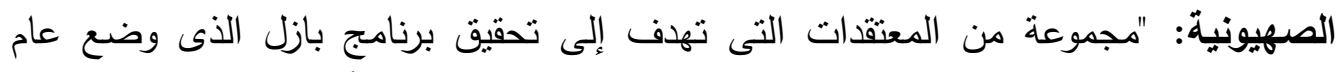

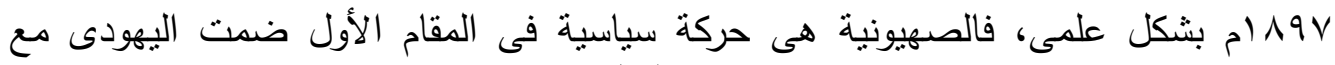

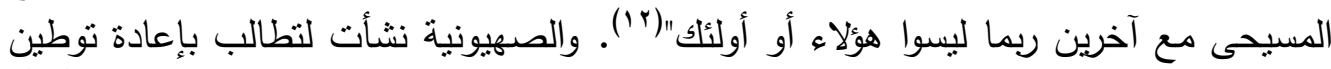

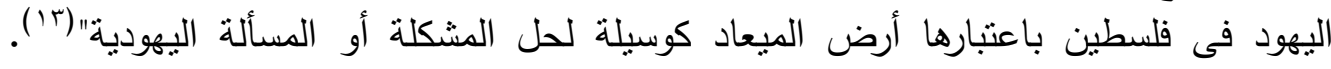

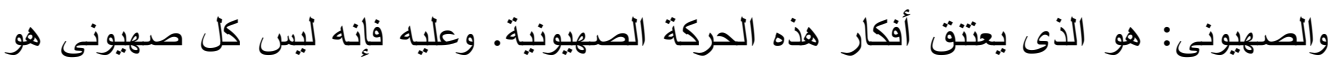
يهودى، فهنالك صهاينه غير يهوديين. اليهود: ترجع هذه النسمية نسبة إلي أبناء يهودا أحد أبناء يعقوب، "الذين أصبحوا يمثلون البقية

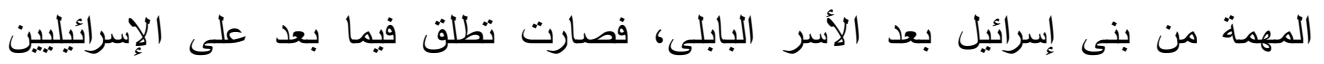

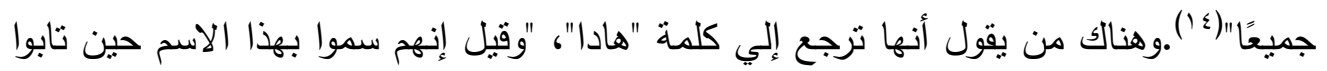

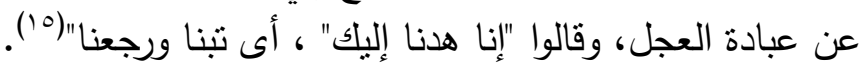


المرأة اليهودية: هي من ولدت من أم يهودية، وتؤمن بالديانة البهودية، وهي "ثخصية لها

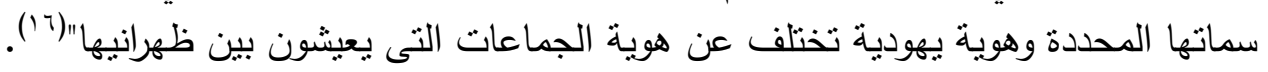

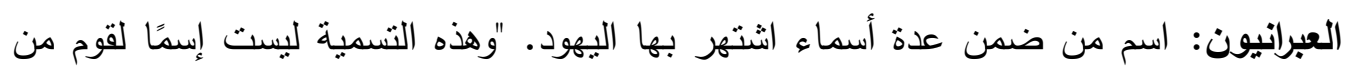

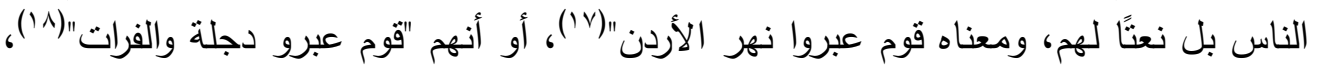

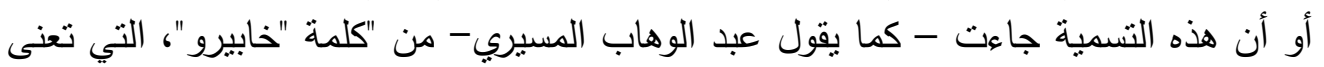

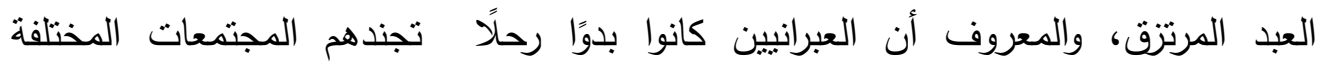

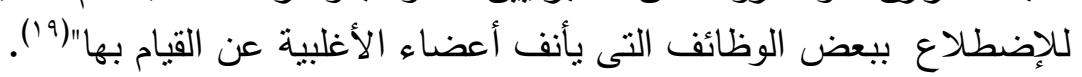
المسرح: شكل من أشكال التعبير الفنية التى ابتدعتها العقلية الإنسانية المبدعة للتهية للتعبير عن واقع الإنسان عن طريق مؤدين يشخصون شخصيات ليست شخصياتهم ، ويلعبون

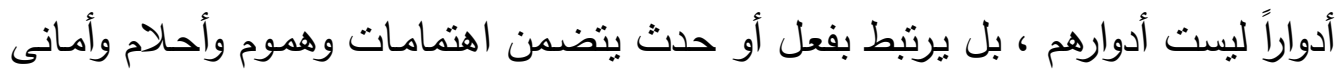

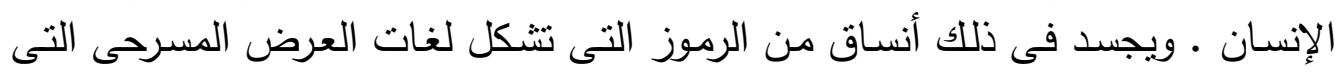

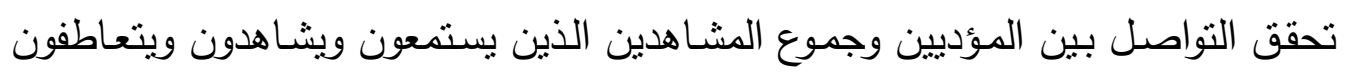

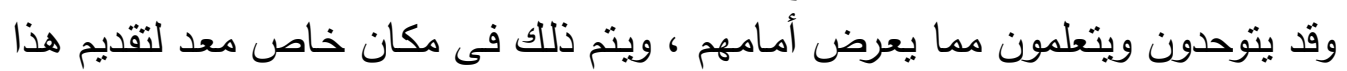

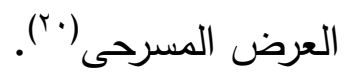
على أحمد باكثير: ولد على أحمد باكثير "فى مدينة سورابايا ، باندونسيا بشرق جزيرة جاوة فى المى

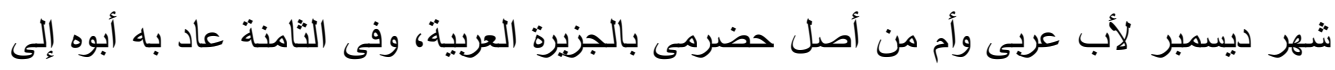

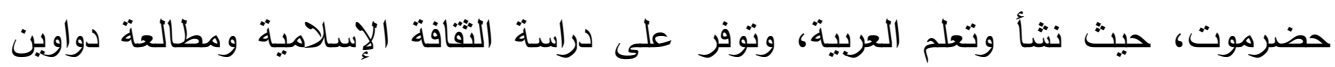

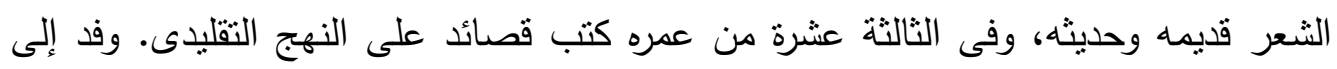

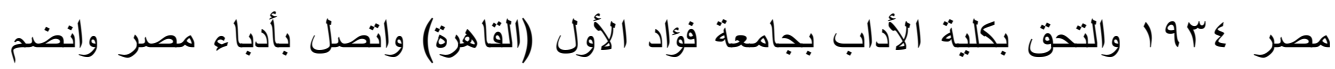

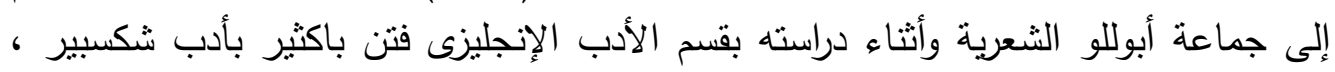

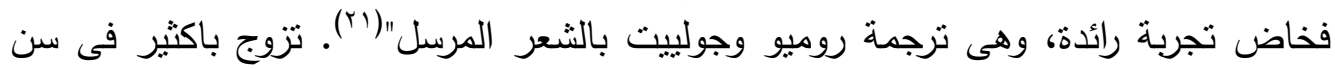

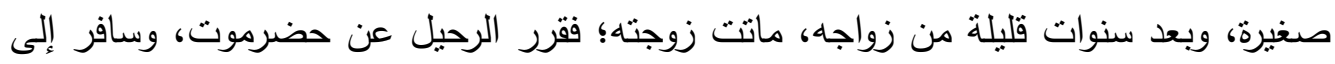

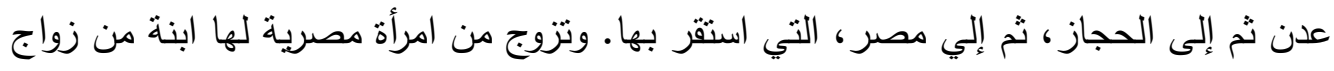

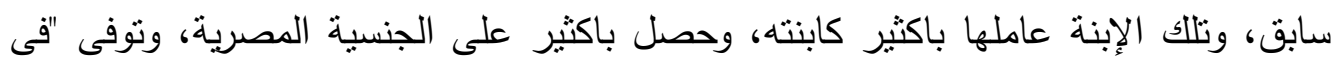

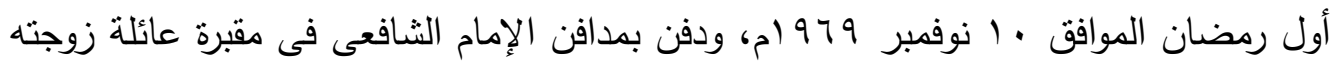

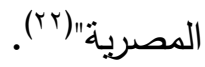
صورة المرأة اليهودية في مسرح باكثير تمهيد: اليهود هم قوم كانوا يعيشون فى شبه الجزيرة العربية فى القرن الثامن عشر قبل الميلاد، إئا

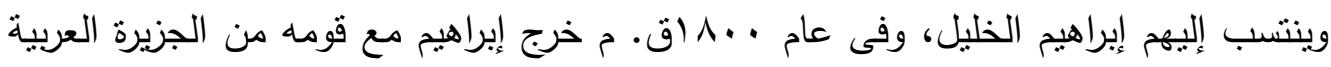

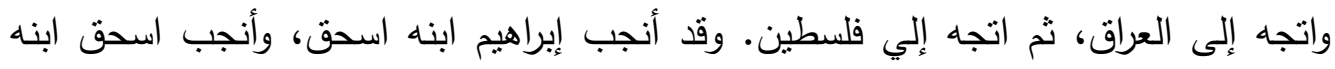




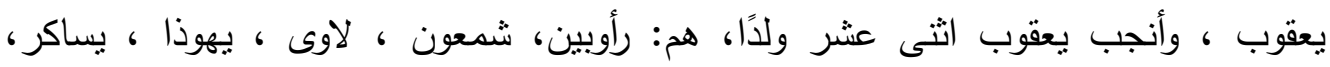

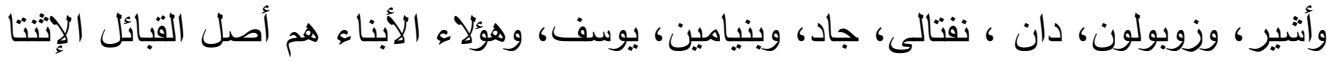
عشرة الثهيرة فى التاريخ والتوراة.

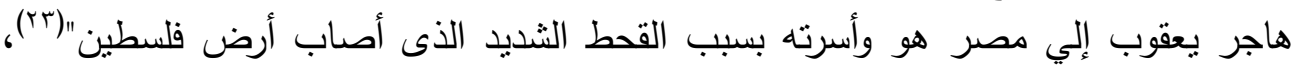

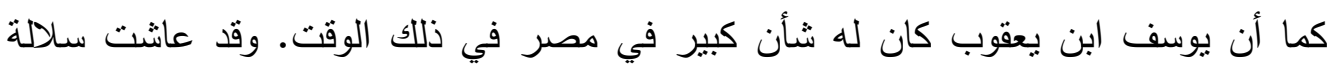

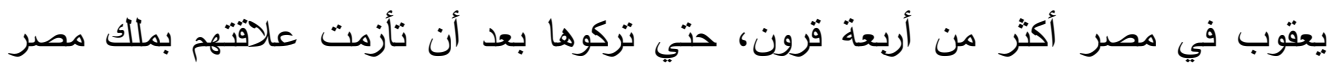

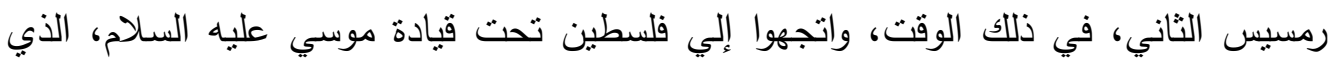

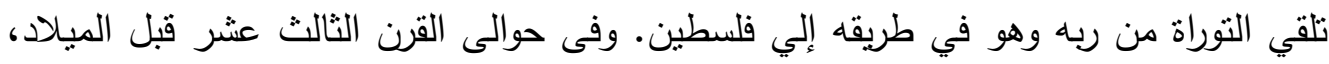

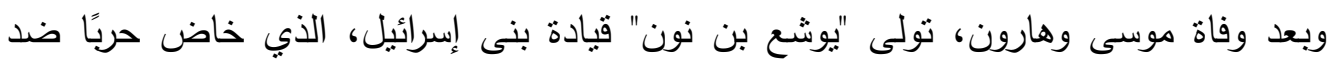

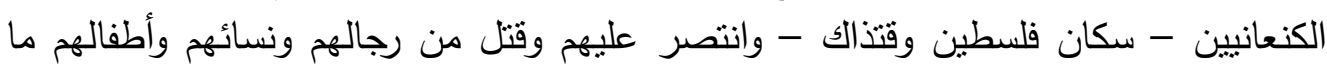
استطاع إلى ذلك سبيلًا (ك ب). وقد خضعت جميع المدن الفلسطينية تحت سيطرة اليهود في عهد الملك "داود"، واتخذ من

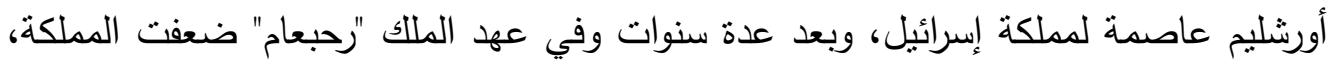

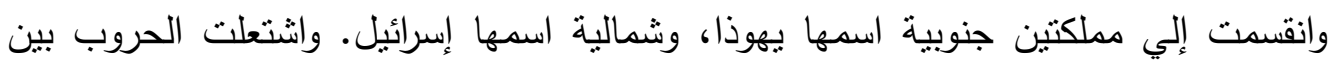

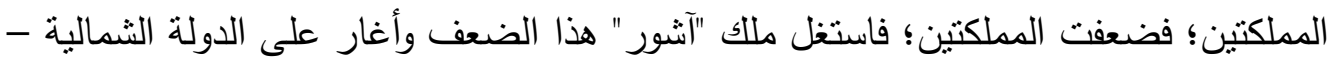

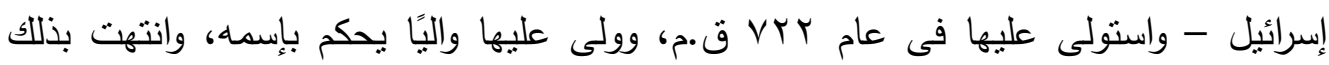

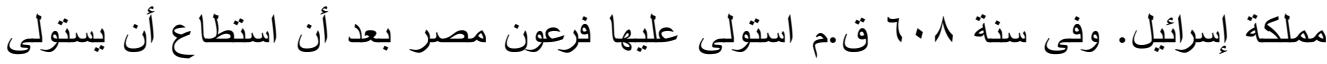

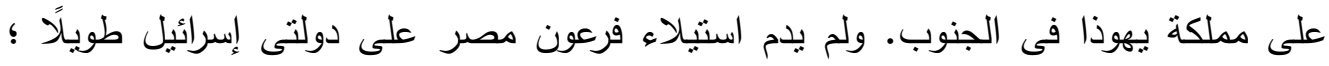

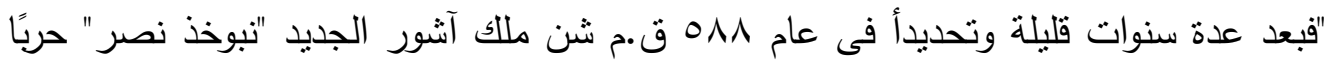

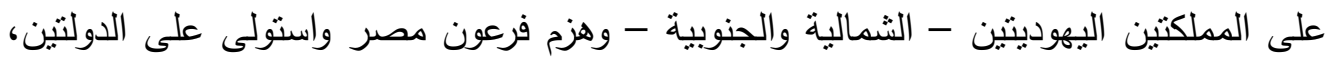

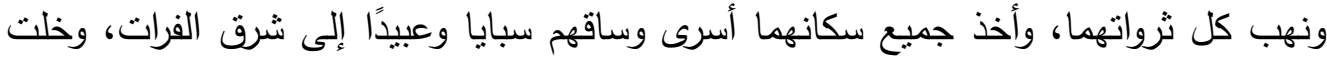

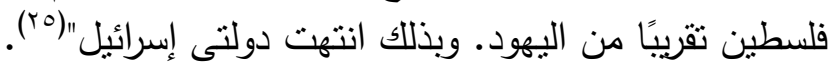

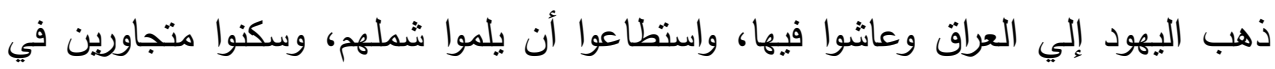

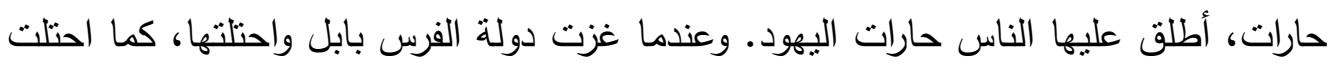

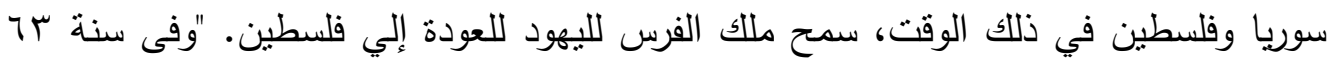

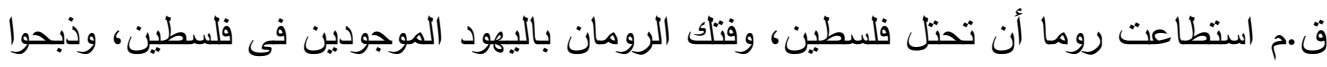

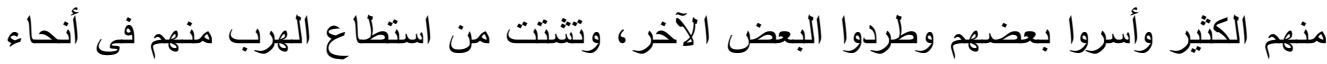

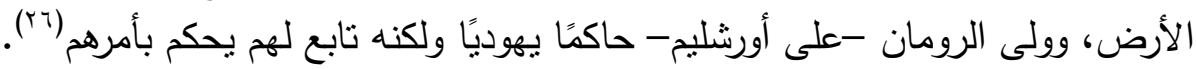

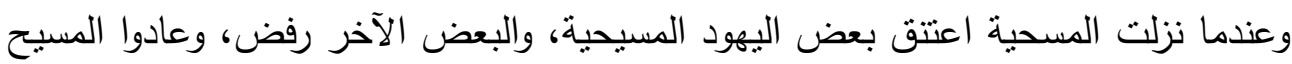

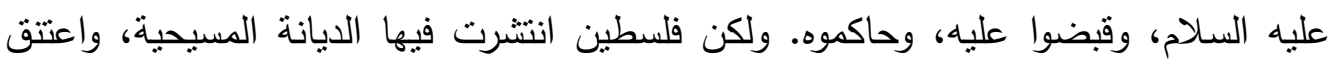
أغلب سكانها الديانة المسيحية وأصبحت فلسطين ولاكين دولة مسيحية بنهاية القرن الرابع الميلادي. وقد نشتت اليهود بعد ذلك في كل بقاع الأرض، ولم يبقي في فلسطين إلا عدد قليل منهم. وقد 
عاش اليهود بين شعوب العالم مشتتين، واختلقوا مشاكل كثيرة في كل بلد عانشوا فيها، واتسم

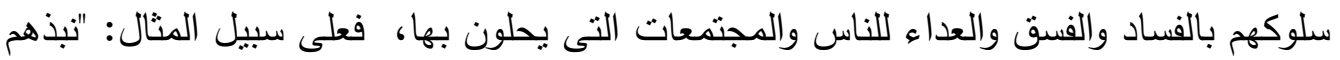

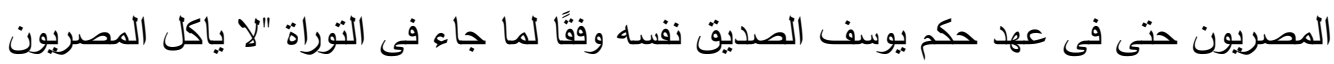

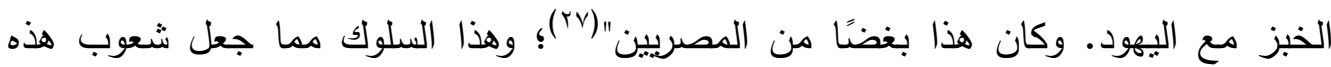

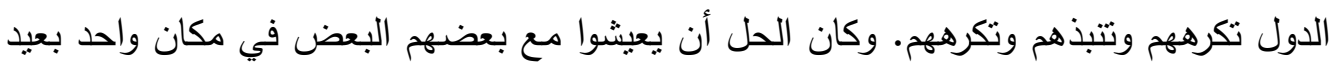

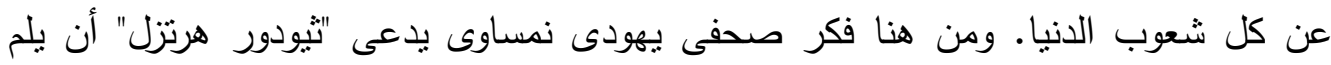

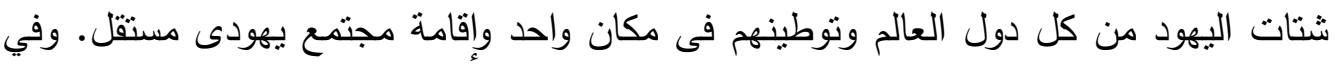

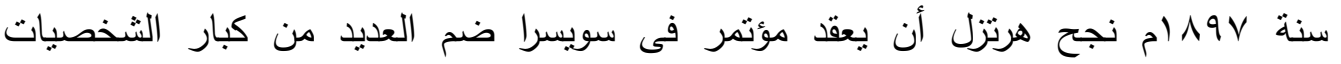

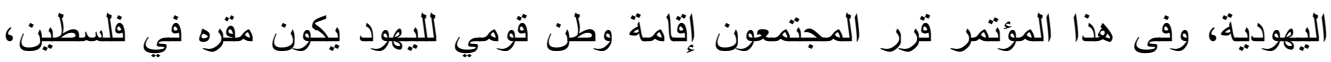

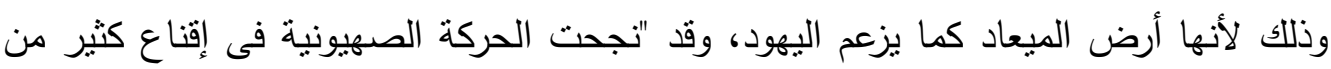

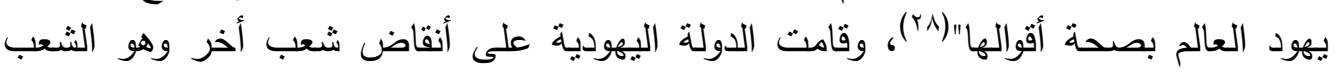
الفلسطينى.

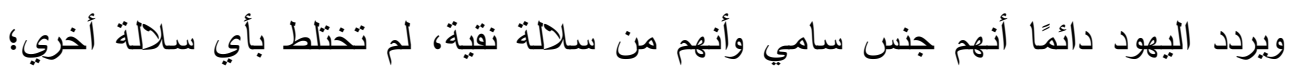

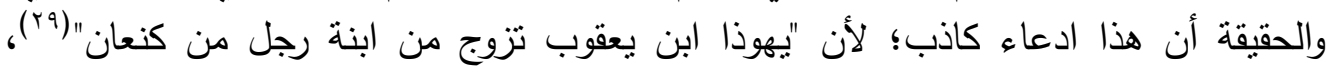

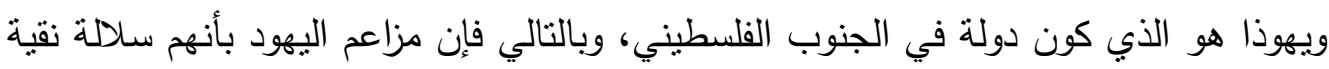

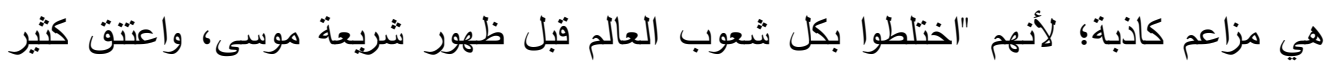

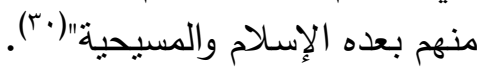

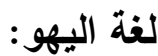

لغة اليهود الأساسية هى اللغة العبرية وسميت بهذا الإسم نسبة إلى نعتهم بالعبرانيين، وكانوا

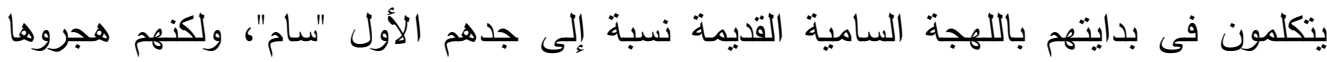
وتكلموا باللهجة الكنعانية عندما هاجروا إلى بلاد الثام؛ حيث "كانية الكانية الكنعانيون يؤلفون معظم

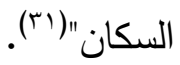
المسرحيات - عينة البحث - البكان هي مسرحيات: شيلوك الجديد، إله إسرائيل، التوراة الضائعة، شعب الهاته المختار. وفي

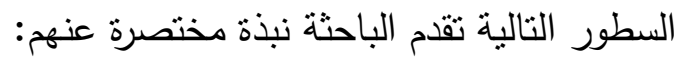

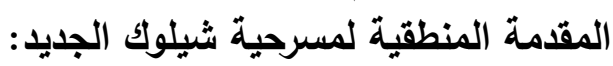

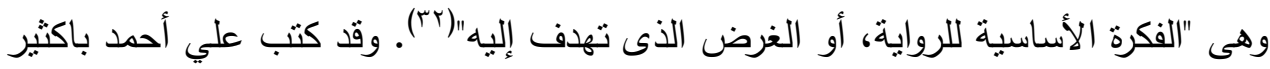

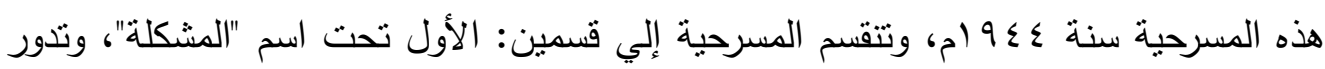

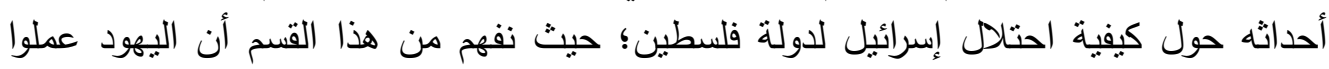

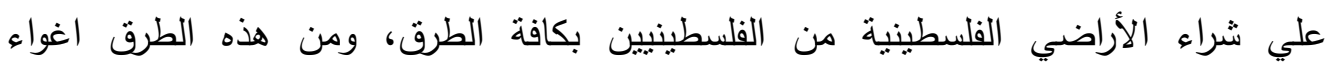

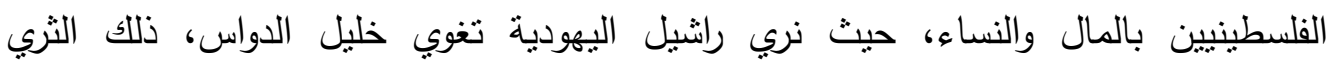
الفلسطيني وتجعله يبيع أرضه من أجل الإنفاق عليها، وعلي لعبة القمار التي جعلته يلعبها، 
وذللك بتخطيط من "ثنيلوك"، وبعد أن قضت علي خليل الدواس، نركته وذهبت إلي "عبد الله

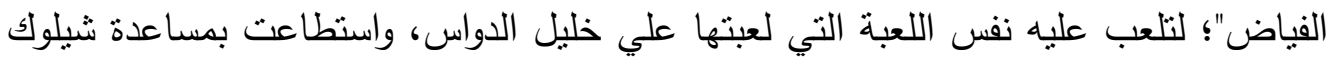

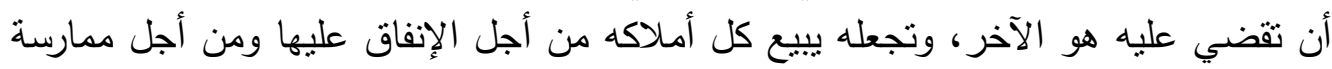

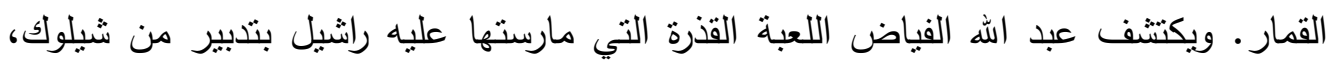
ويعود نادمًا إلي عمه "كاظم" طالبًا السماح منه؛ فيسامحه عمه، كمانه كما يطلب السماح من خطيبته نادية، ولكنها لا تسامحه:

نادية : كلا لا أضع يدى فى يد تلوثت بخيانة الوطن!"("r). وفي نهاية القسم الأول من المسرحية يقرر عبد الله الانضمام إلي منظمة فلسطينية وطنية

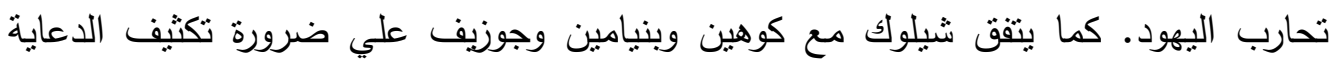

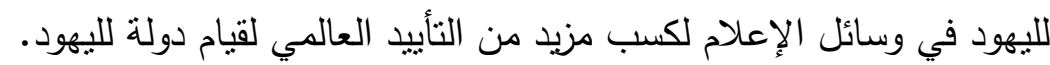

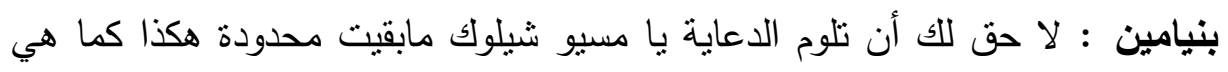
اليوم. يجب تعزيزها وتوسيع نطاقها حالاً.

كوهين : ولا سيما وقد بدأ العرب يفكرون في إنشاء مكاتب للاعاية العربية في إنجلترا

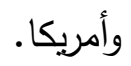

بنيامين : نعم ، هذه المكاتب ستتافس دعايتتا في استمالة الرأي العام في تلك

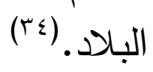

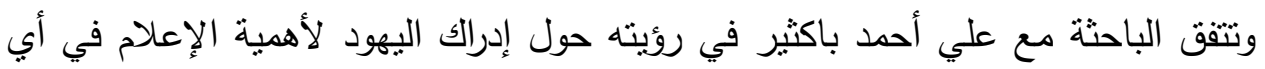

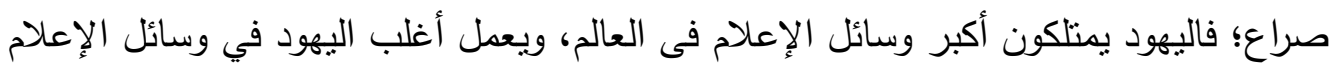

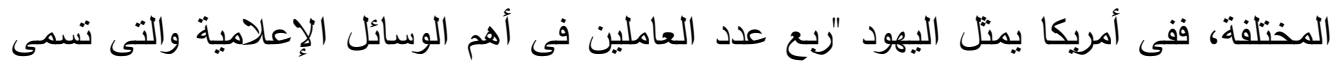

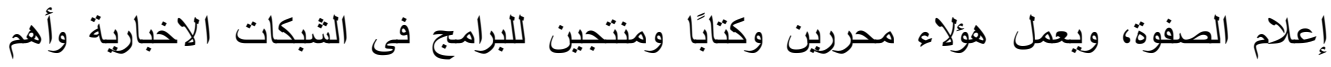

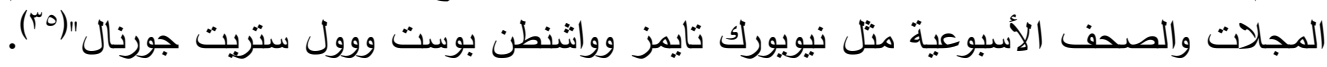
وفي هذه المسرحية يؤمن اليهود أن فلسطين هي أرضهم التي نركوها منذ أكثر من ألنئ ألفين عام.

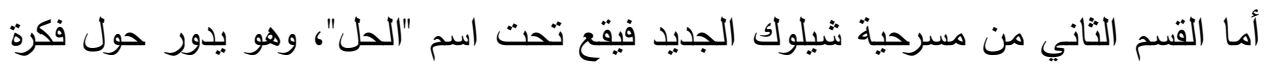

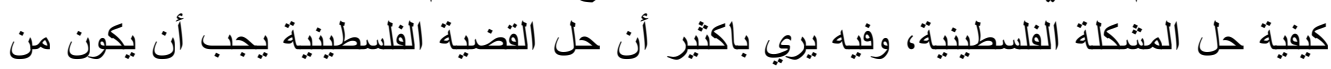

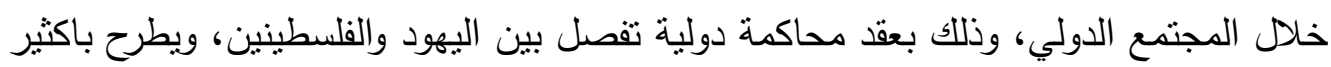

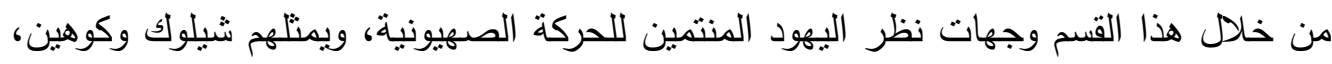

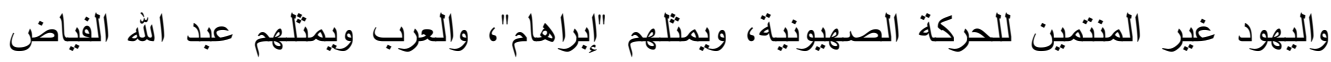

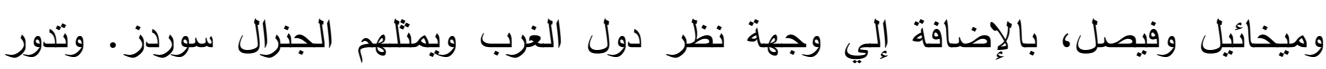

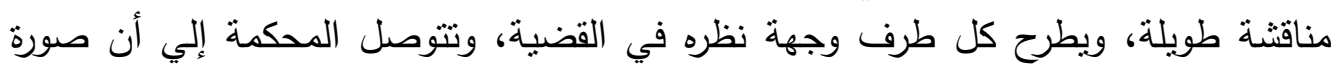

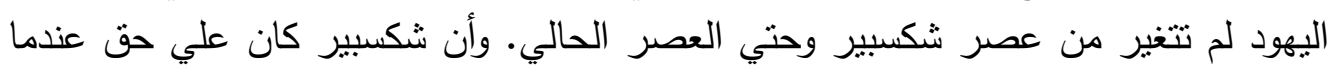

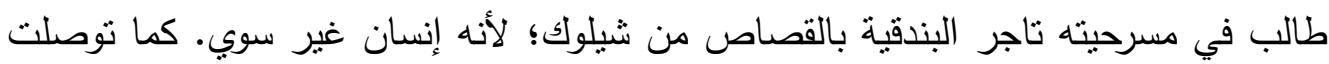

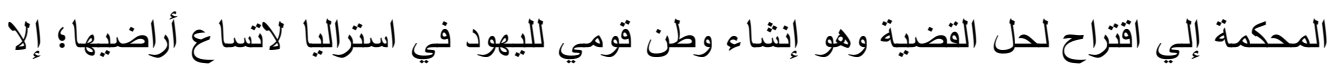




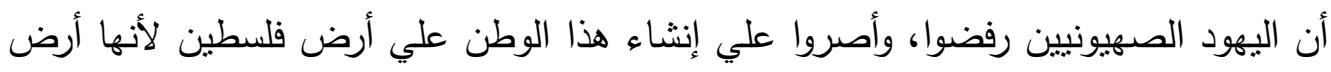

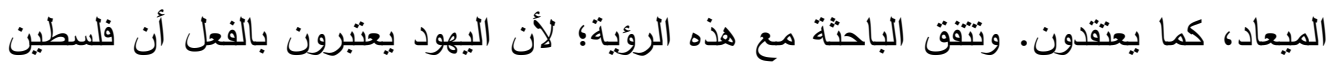

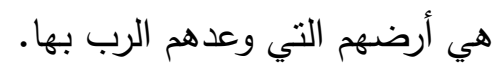
وتتتهي المحكمة إلي أن اليهود ليس لهم الحق في فلسطين، حيث أنهم عاشوا عليها قرنين

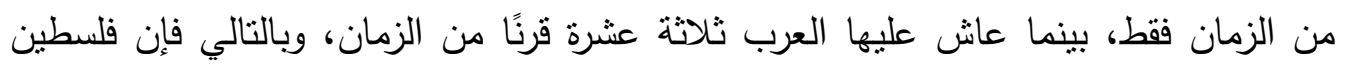

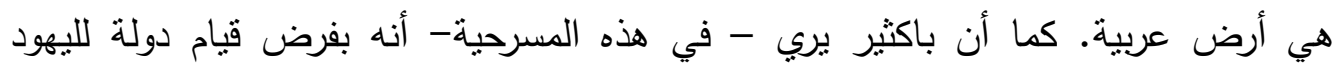

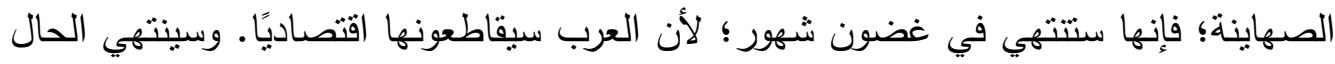

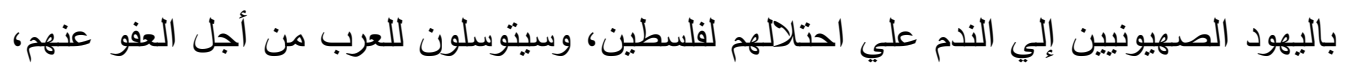

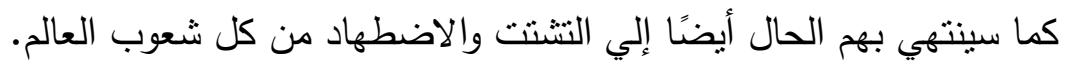

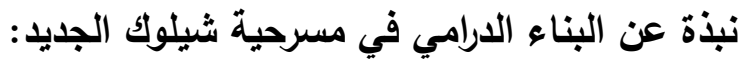

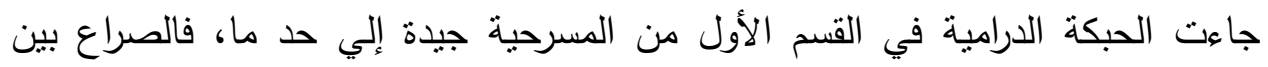

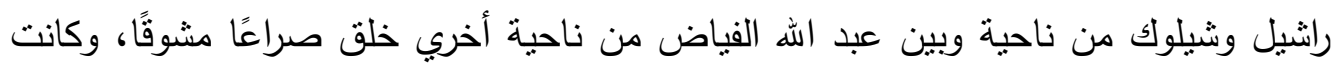

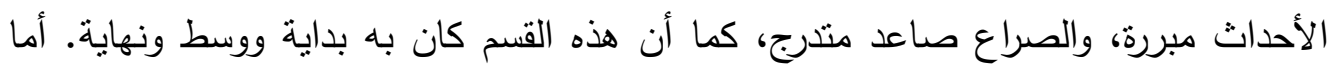

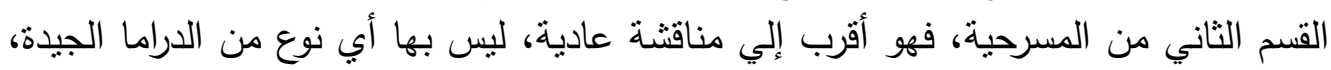

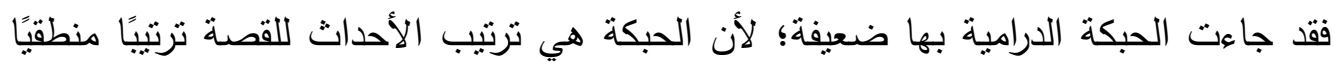

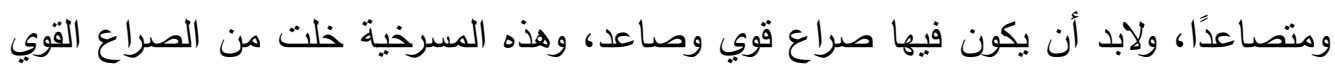

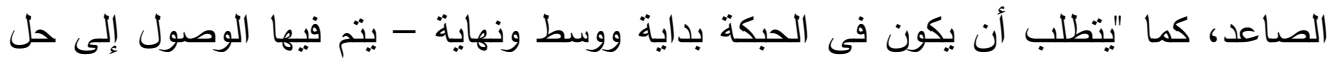

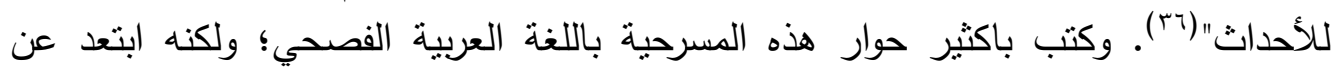

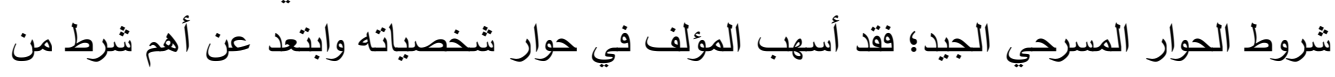

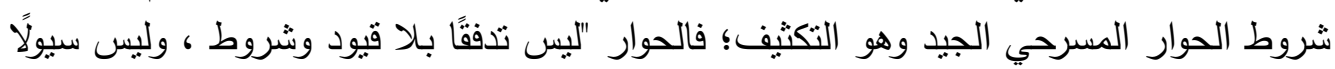

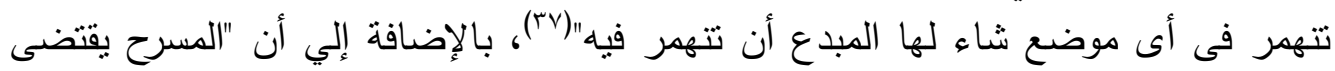

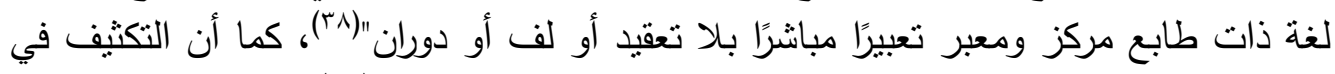

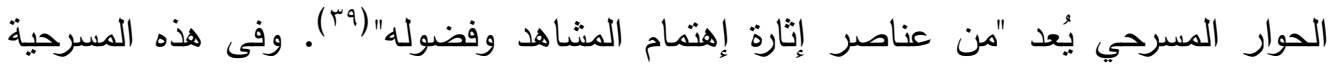

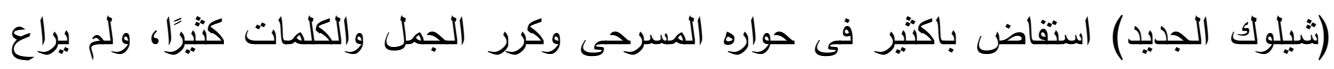

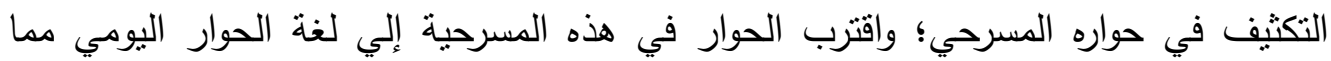

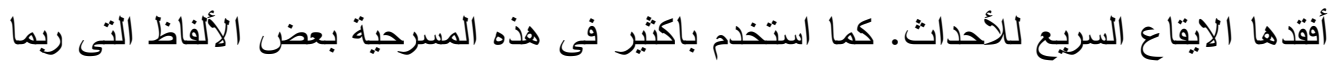

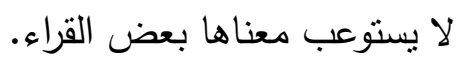

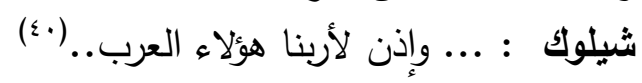

عبد الله : ... ووضع الندي في موضع السيف للعدا.. مضر كوضع السيف في موضع

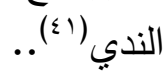




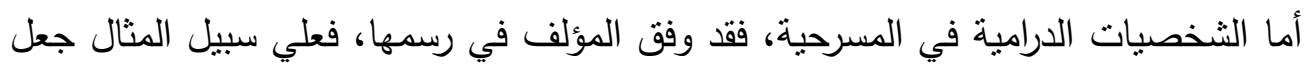

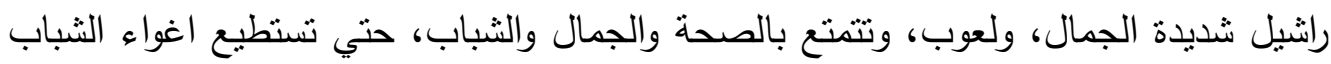
الفلسطينيين: عبدالله : ... واله لا أدرى بم أدعو اله أن ينعم عليك بعد؟ أبالجمال أم بالصحة أم

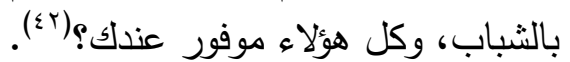

مسرحية إله إسرائيل

فكرة هذه المسرحية استوحاها باكثير من الكتب المقدسة الثلاثة، التوراة والإنجيل والقرآن،

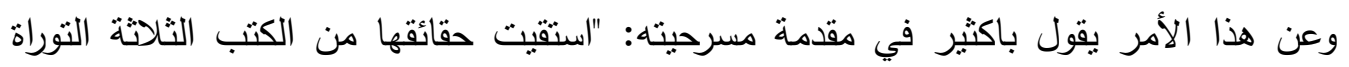

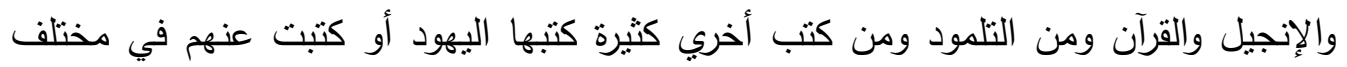

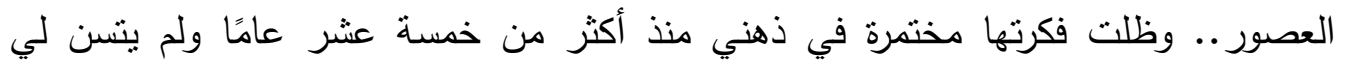

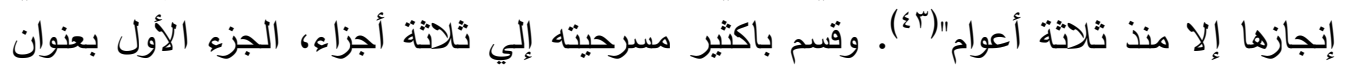

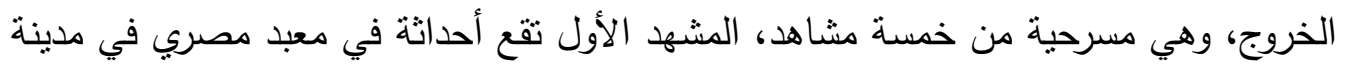

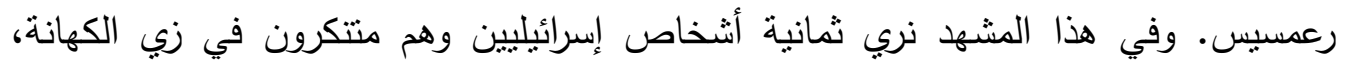

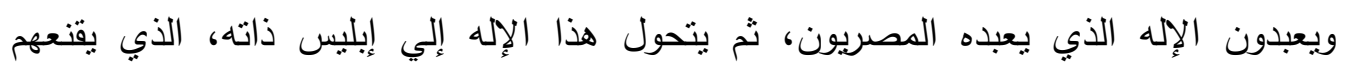

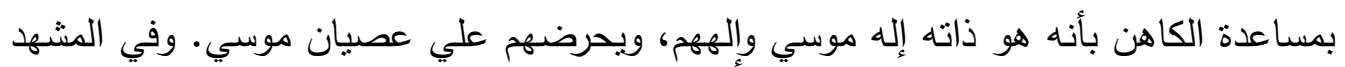

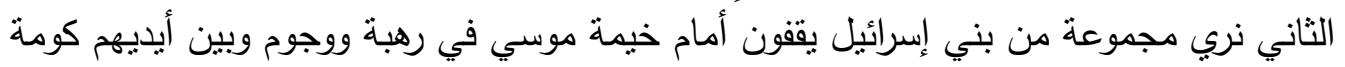

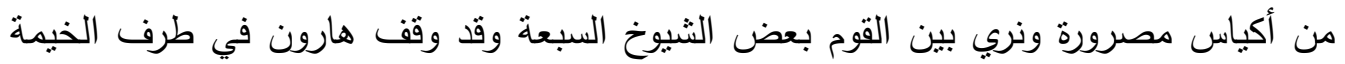

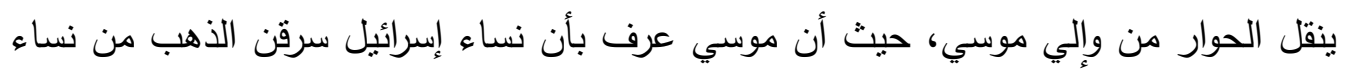
مصر ؛ فغضب غضبا شديدًا.

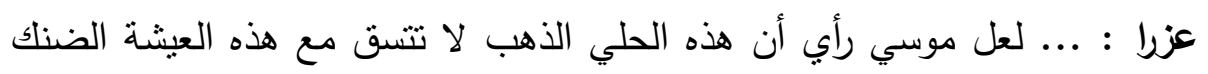

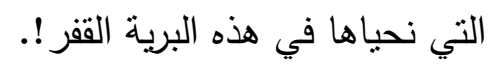

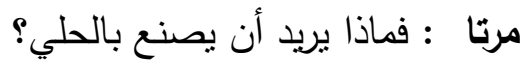

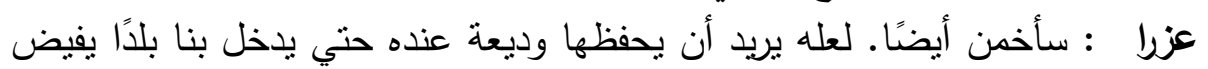

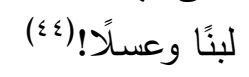

وفي المشهدين الثالث والرابع أراد موسي أن يعيد الذهب إلي نساء مصر مرة ثانية ولكن

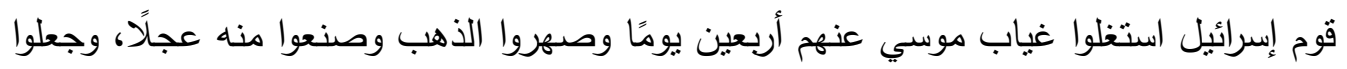

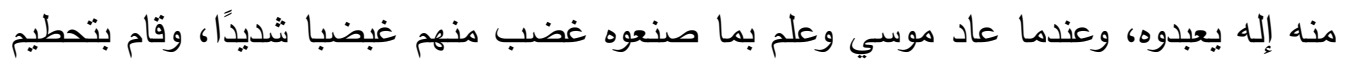

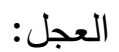

$$
\text { موسي : خبرني من أين جاعوا بهذ؟ : مبذج }
$$

هرون : وثثبوا عليَ بعدك فانتزعوا حلي المصريين التي جمعتها فصاغوا منها هذا

$$
\text { العجل وعبدوه. }
$$


موسي: واستطت أن تعيش بينهم بعد؟ هلا كان بطن الأرض خيرًا للك من ظهرها وقد

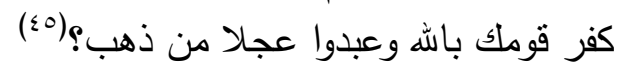

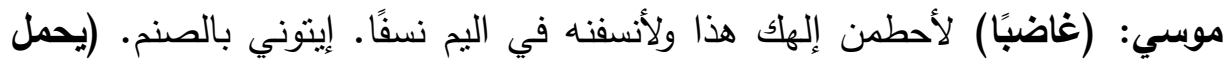

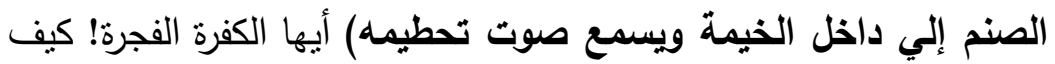

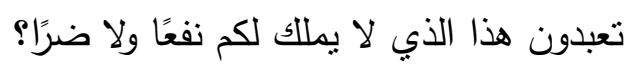

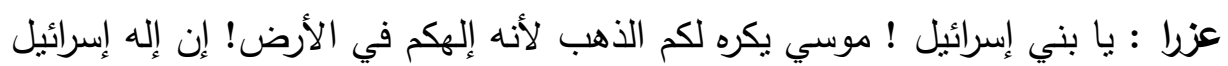

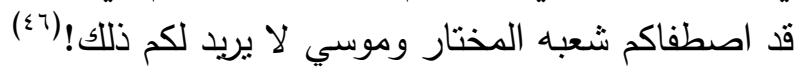

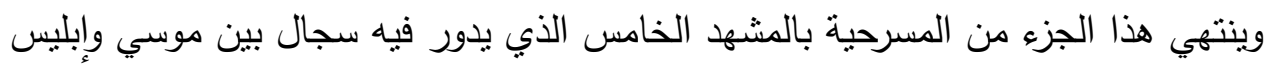

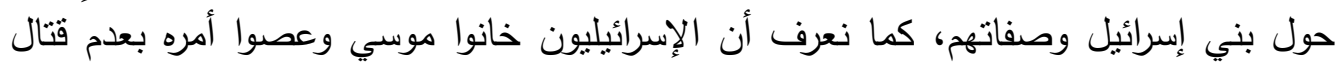

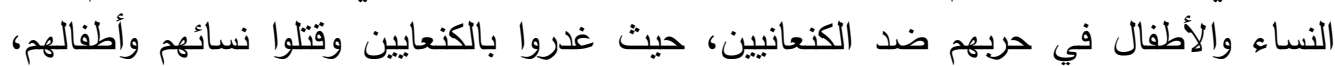

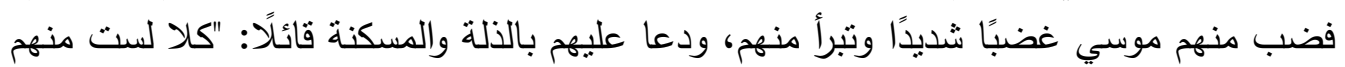

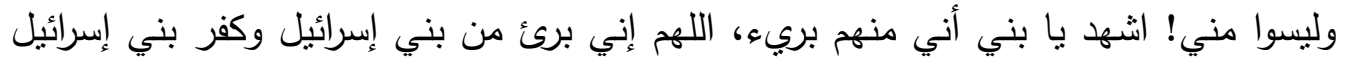

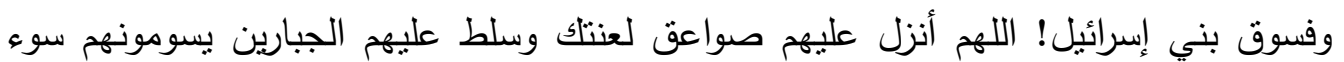

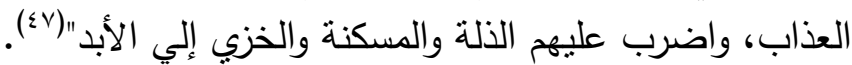

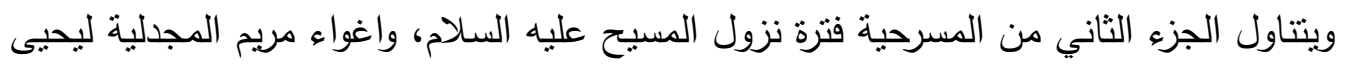
المعددان، ورفضه لاغوائها: يحيى : : هيا انصرفي الآن إلي بيتلك لعل اله أن يتوب عليك.

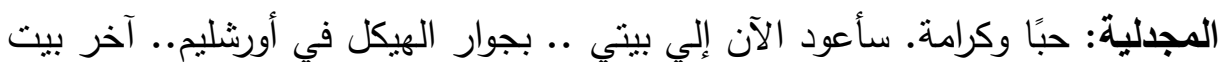

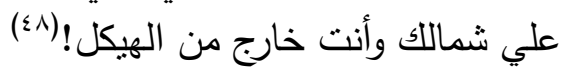
أما الجزء الثالث والأخير فيقع تحت عنوان "الحية" وفيه يثبه علي أحمد باكثير إسرائيل بالحية التي التقت حول العالم كله لتبخ سمومها فيه: إبليس : انظروا هل بقي من بلد في العالم لم تلف جسمها عليه عليه؟

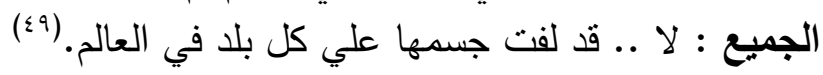

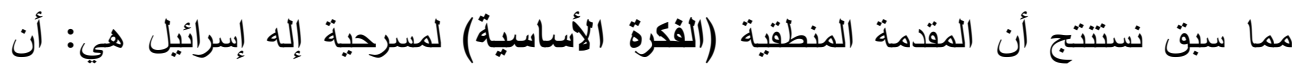

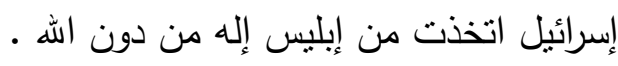

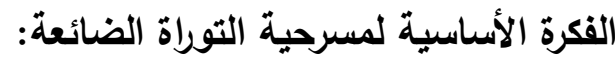

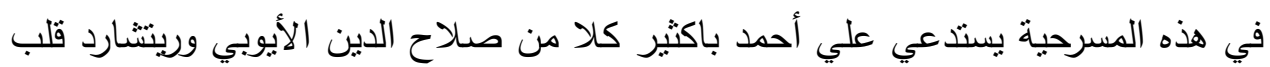

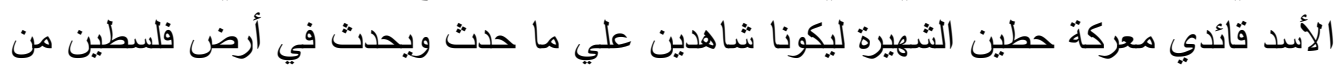
دمار علي أيدي الإسرائيليين، وعلي أيدي فادة بريطانيانيا علينيا وأمريكا الذين سهلوا للإسرائيليين

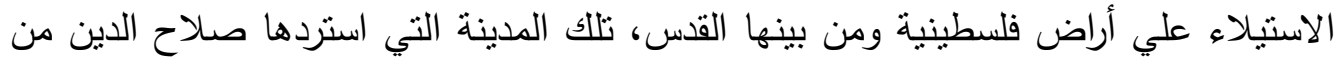

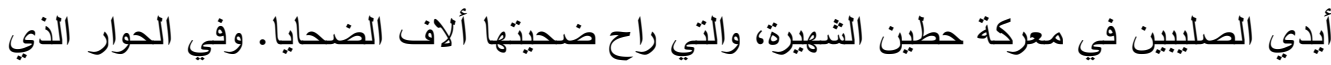

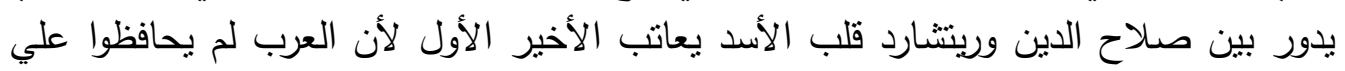


أرض فلسطين، ويلوم نفسه لأنه عقد صلحًا مع العرب بموجبه ترك القس للعرب معتقدًا أنهم سيحافظون عليها:

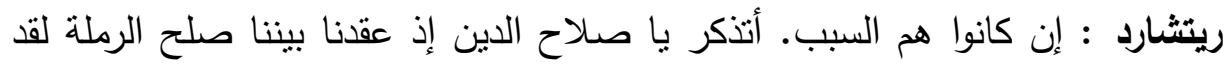

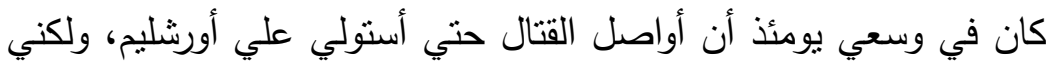

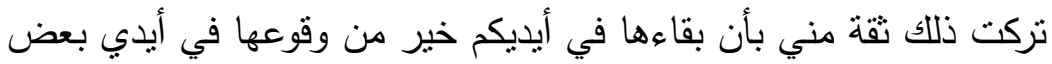

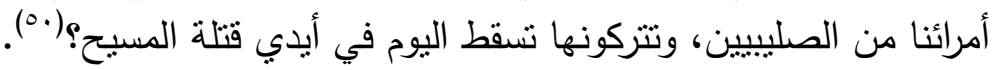

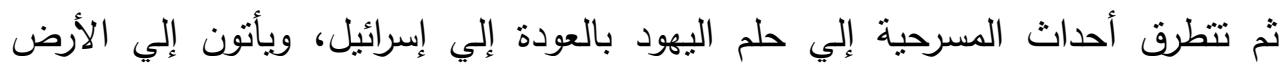

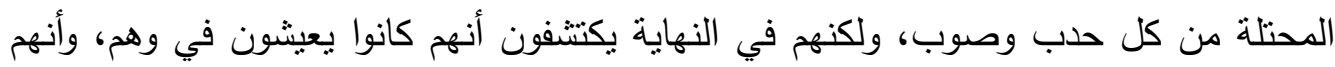

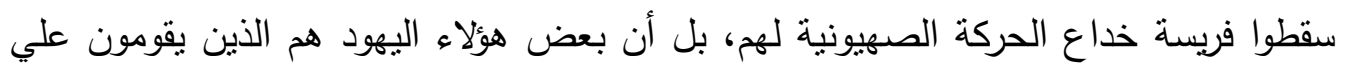

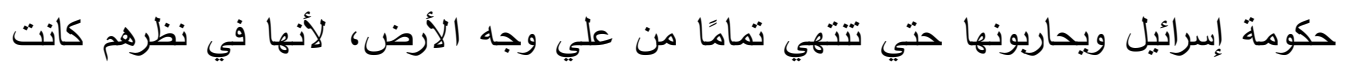

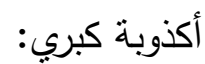

بريارة : ... كل شئ هنا با بنتي علي غير حقيقته؟

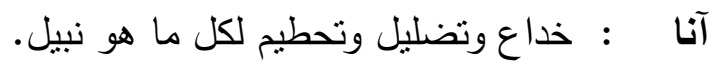

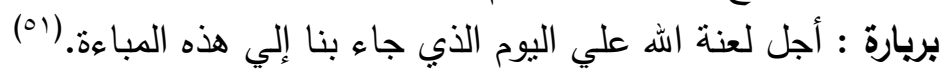

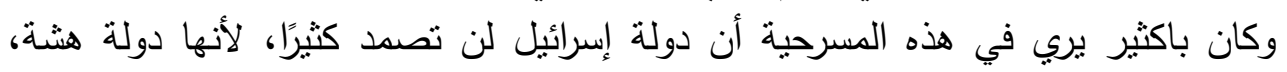

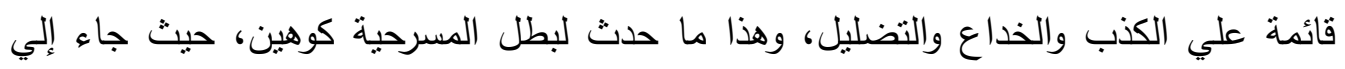

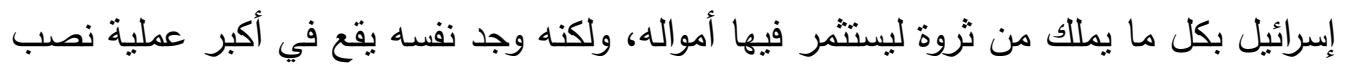

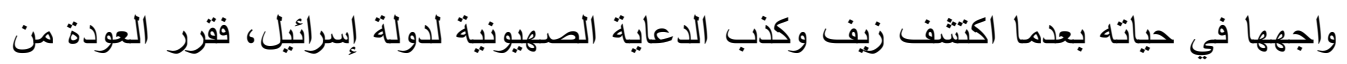

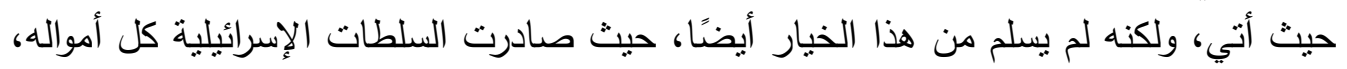

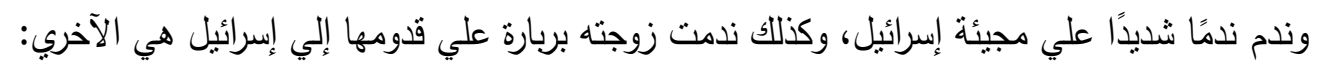

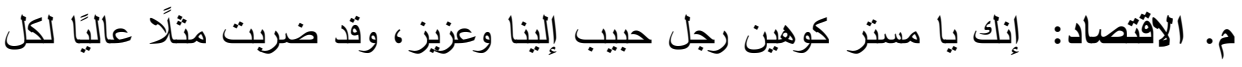

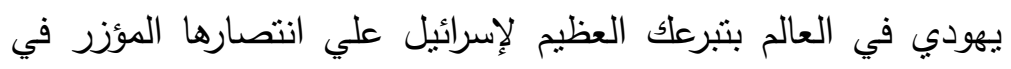

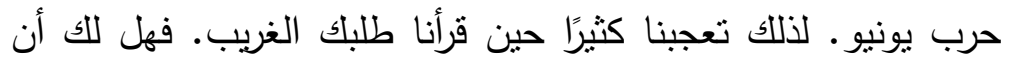

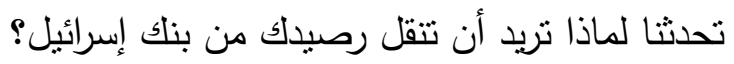

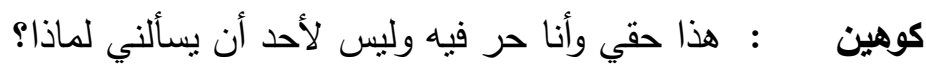

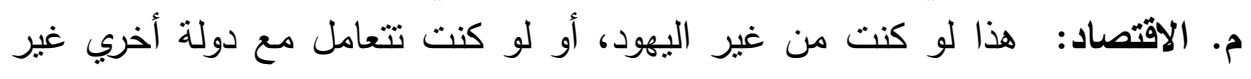
إسرائيل.

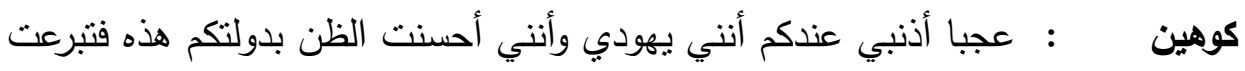

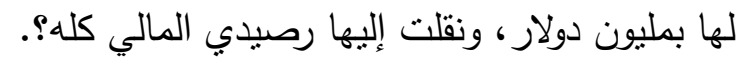

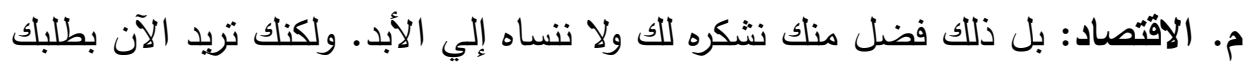

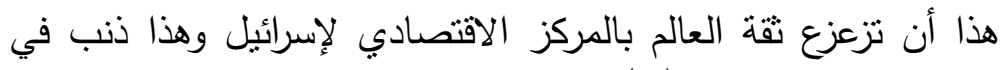

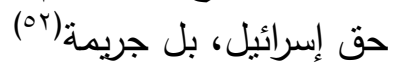




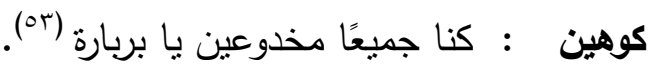

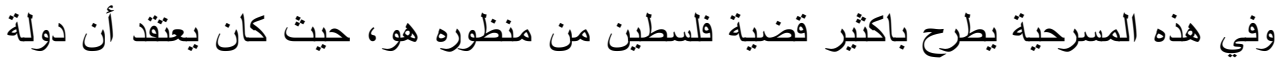

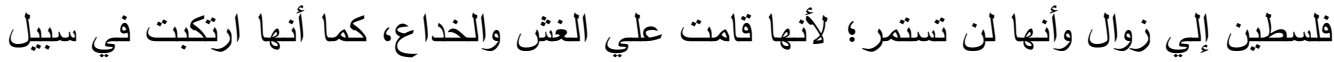
ذللك مجازر في حق الثعب الفلسطيني المسالم تفوق جرائم هنلر النازي في حق الثقاء اليهودي:

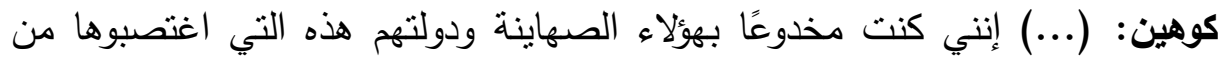

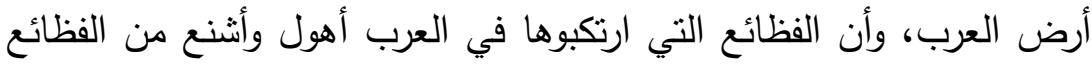

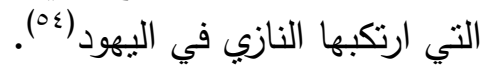

من السطور السابقة نستتنج أن الفكرة الأساسية للمسرحية التي بني عليها علي أحمد بكثير أحداث مسرحيته هي أن "الحركة الصهيونية لن تسنطيع إقامة دولة إسرائيل".

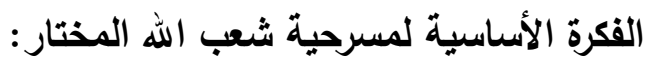

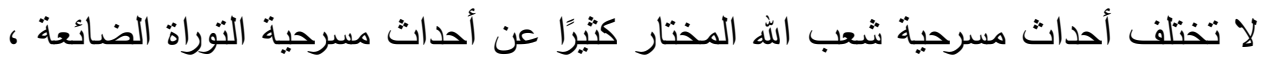

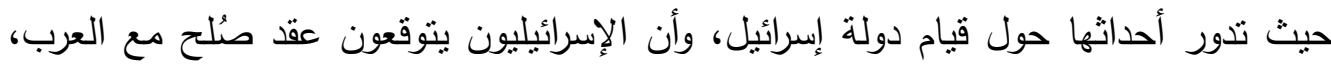

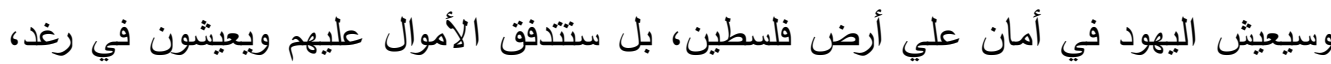

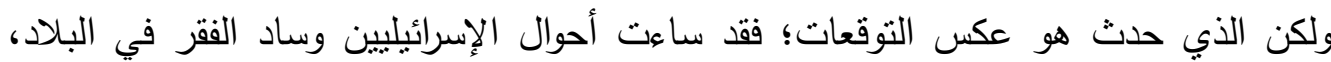

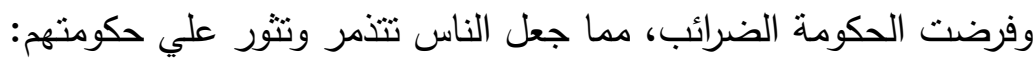

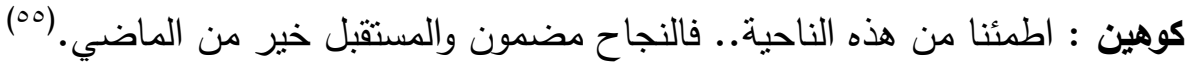

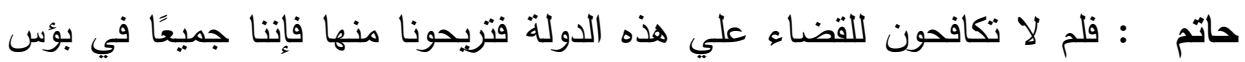

$$
\text { سيمون: (متعجبا...) .. حتي أنت يا عم حاتم؟! }
$$

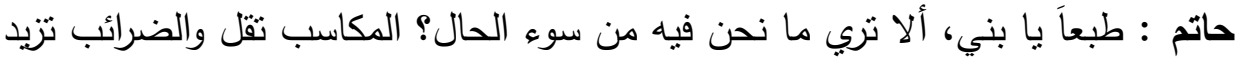

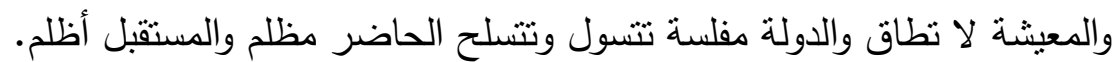

$$
\text { سيمون: لكن الصهيونين هم الغالبين في كل مكان. }
$$

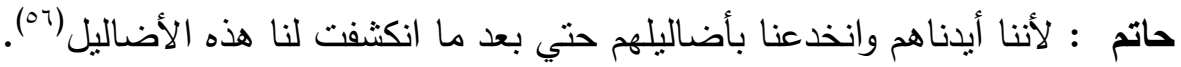

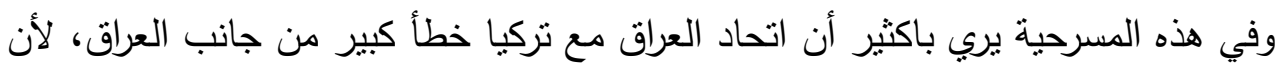

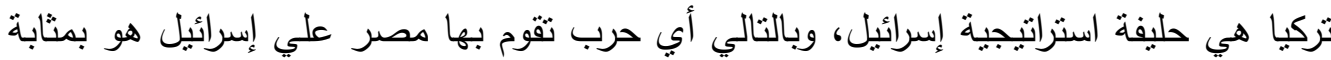

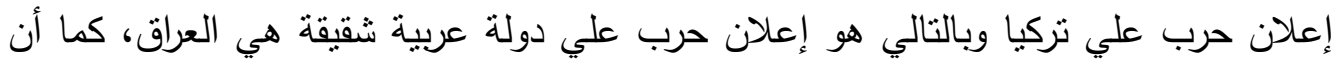

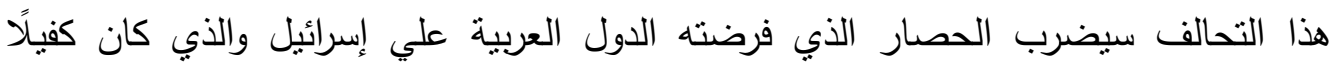
بالقضاء علي دولة إسرائيل: سارة : يقولون أن الفرج سيأني دع هذا الحلفالتركي العراقي حاتم : هذا كلام. 
سارة : قد أحدث صدعًا خطيرًا في جبهة الدول العربية؛ فانقسمت فريقين. فريقًا مع

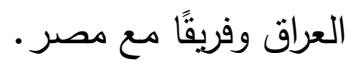

حاتم : هبي أن ذلك حدث، أفلا تكفي مصر للقضاء علي دولتتا الهزيلة. تذكري أن مصر اليوم غير مصر بالأمس.

$$
\begin{aligned}
& \text { سارة : هذا صحيح ولكن مصر لا تسنطيع أن تحارب العراق. }
\end{aligned}
$$

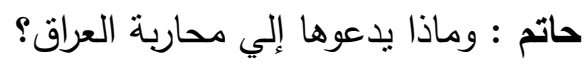

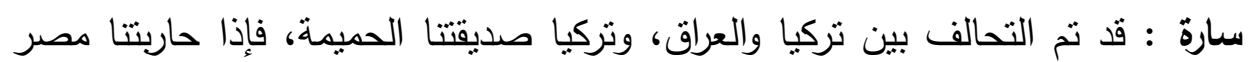

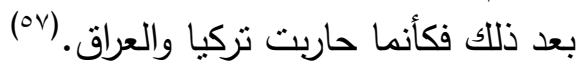

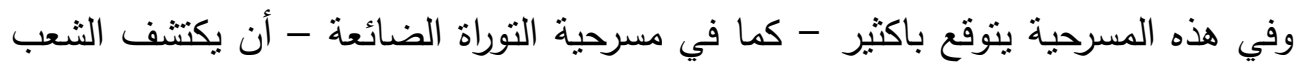
اليهودي زيف وكذب الحركة الصهيونية؛ فيثور علي حكومة إسرائيل وتتنهي الدولة الإسرائيلية الوليدة:

ليفي : وأنا معك يا أندرسون ، اعتبرني شريكك في كل ما تتفقه في هذا السبيل،

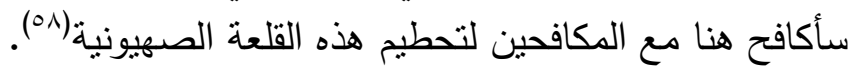

أندرسون: كلا لا داعي إلي ذلك، أنا وأنت با ليفي شئ واحئ لاحد، يكفي أننا كثفنا حقيقة

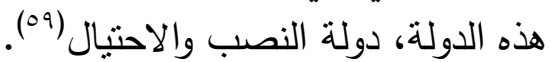

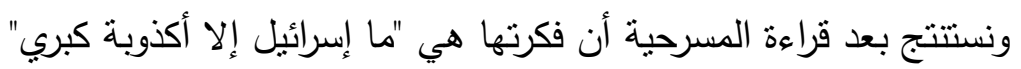
صورة المرأة اليهودية في مسرح علي أحمد باكثير:

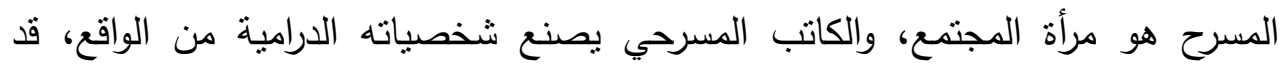
يضيف إليها من خياله، ولكن في الغالب يستقي معظم معالمها من خبراته وثقافته التي استمدها

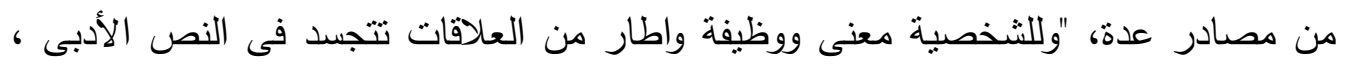

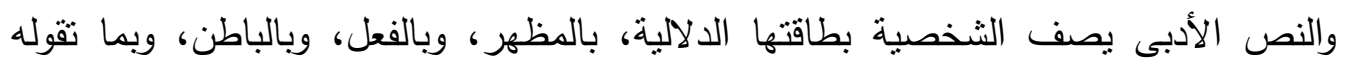

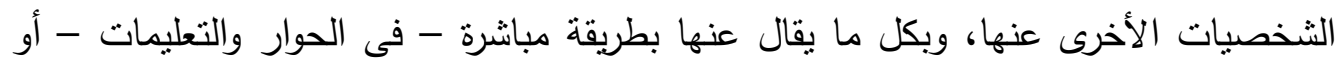

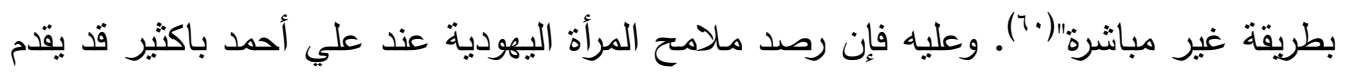
للمتلقي المسرحي صورة ذهنية عنها أقرب إلي الحقيقة. وفي السطور التالية ترصد الباحثة ملامح تلاك الصورة في مسرح علي أحمد باكثير :

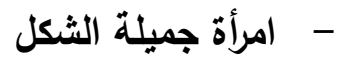
صورة المرأة اليهودية في مسرح باكثير جميلة من حيث الثكل، فهي تتمتع بالوجه الحسن

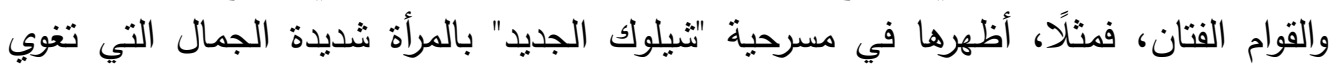

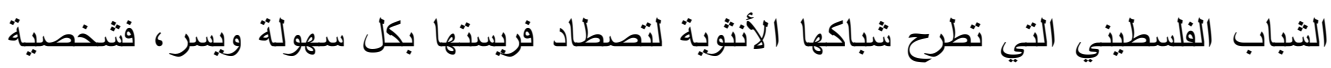

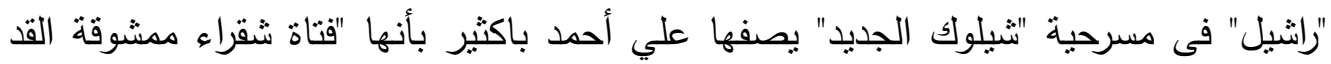

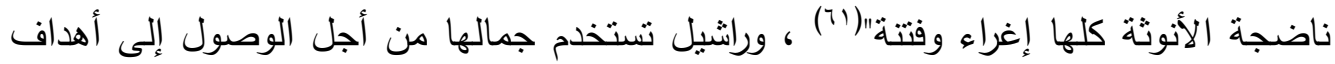

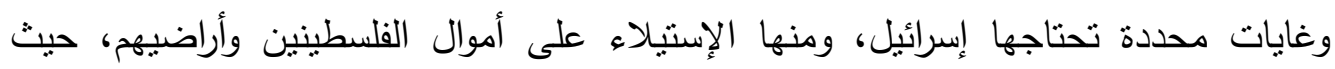




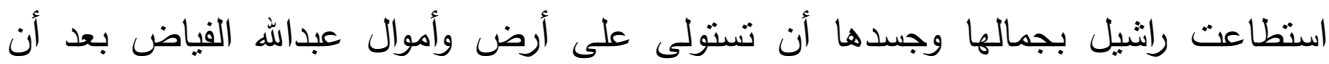

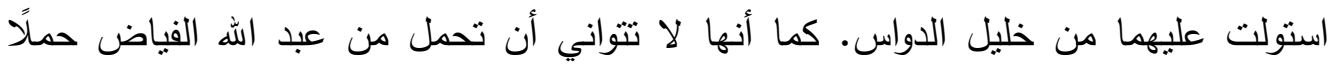

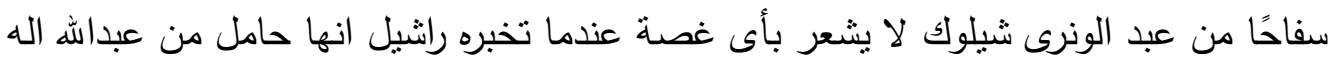
الفياض من أجل زيادة النسل في إسرائيل:

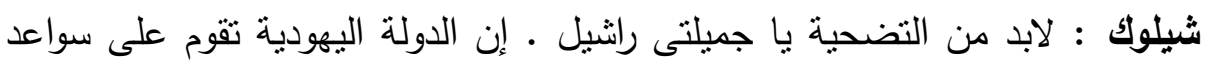

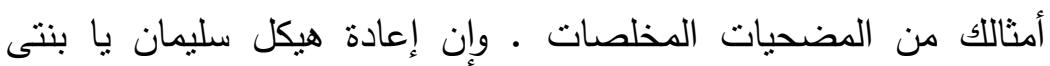

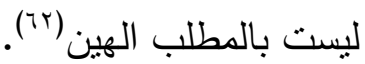

وتتفق الباحثة مع رأي علي أحمد باكثير هذا؛ حيث أن إسرائيل لا تتواني في استخدام

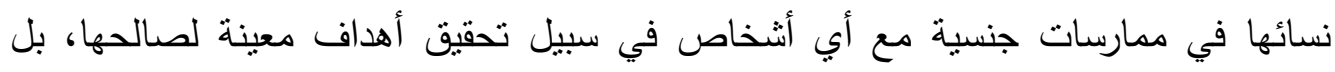

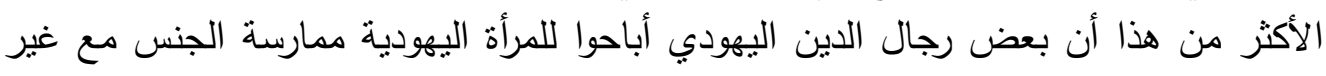

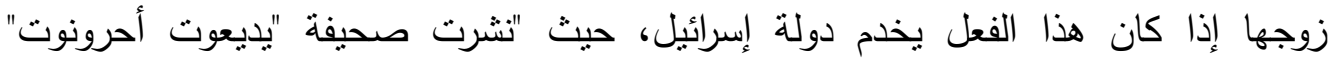

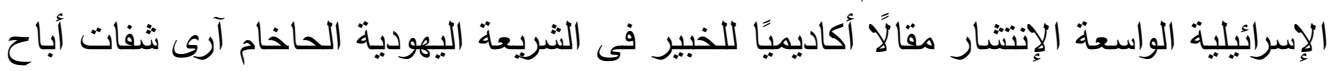

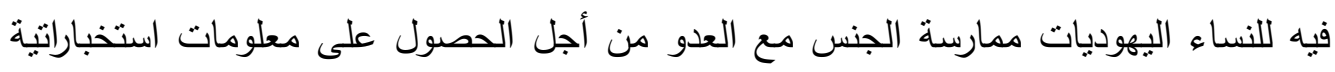

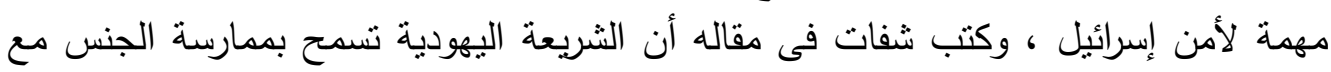

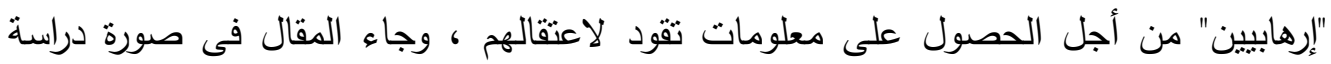

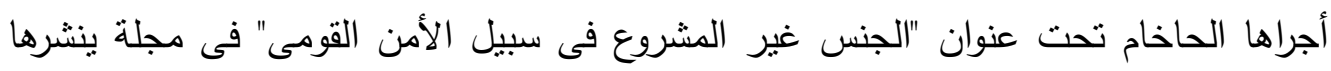

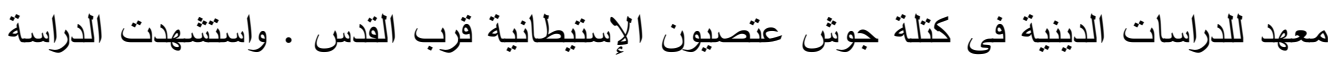

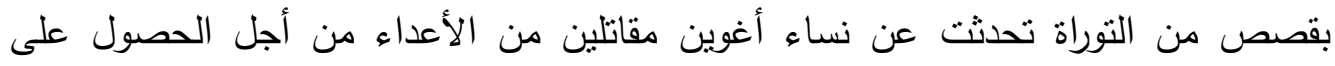

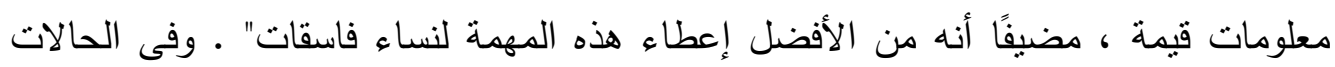

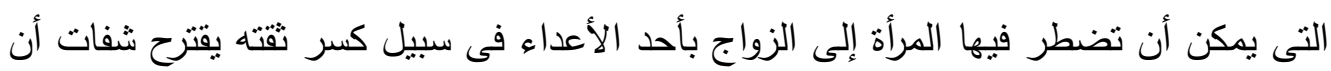
تطلق زوجها الحقيقى أولا"(Tr"). وفي مسرحية "إله إسرائيل" يصف لنا الصورة الثكلية للبطلة اليهودية للمسرحية بقوله:

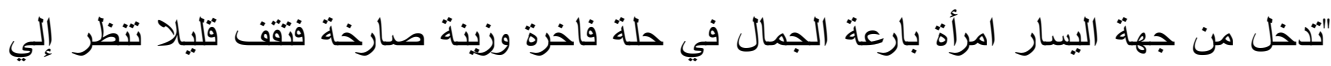

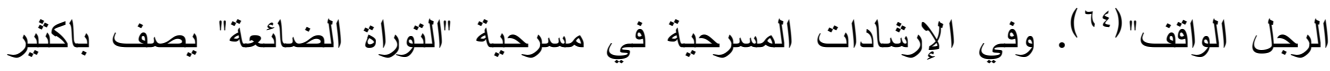

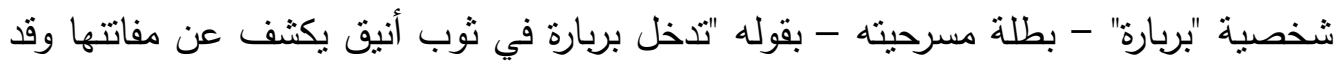

ازداد وجهها تألقًا ونضارة!"(70")

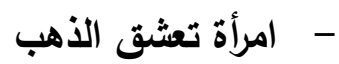

في مسرحية "إله إسرائيل" يسرد علي أحمد باكثير في هذه المسرحية قصة سرقة نساء

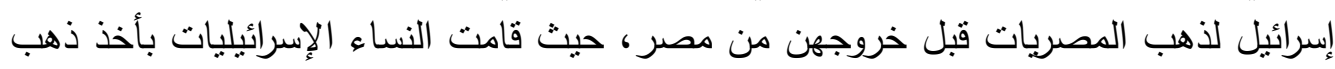
جيرانهن من المصريات بدعوي السلف لفترة قصبرة وأنهن سوف يقمن برده في أسرون أسرع وقت؛ ولكن كانت هذه حيلة منهن لسرقة ذهب جيرانهن من المصريات؛ لأنهن كانوا يعرفون أنهن فين فئن 
سوف يتركون مصر بأوامر من فرعون. وعندما علم موسي بهذه القصة أمر بأن يصادر هذا

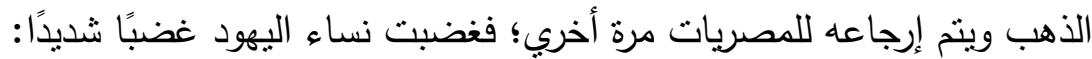
رجل : إن كان يريد أن يصادر هذه الحلي فإنها الكارثة!

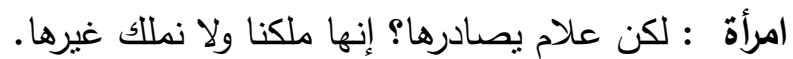

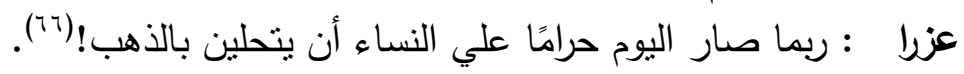

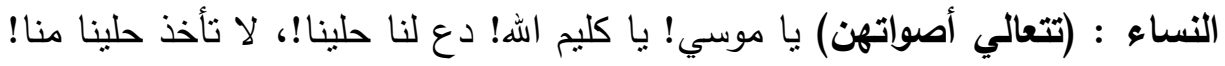

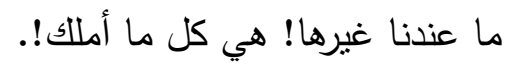

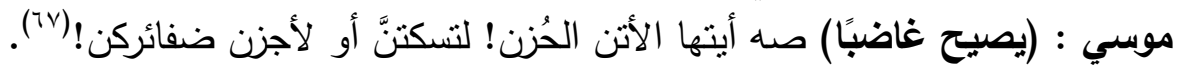

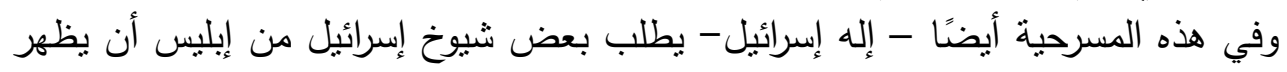

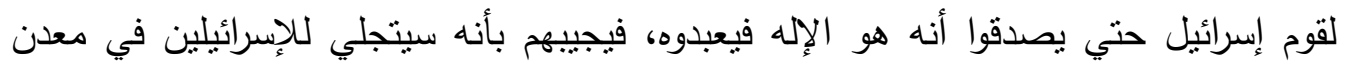

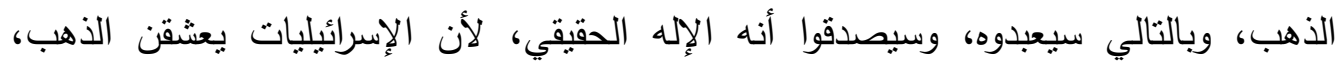
ويقدسونه كأنه إله:

إبليس : لا تخافوا.. سأكون معكم عليه ولن أتخلي عنكم، سأتجلي لكم في كل حين.

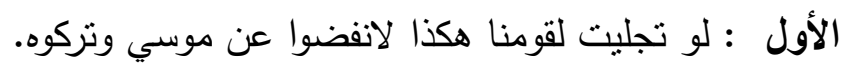

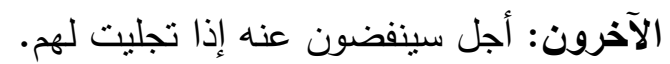

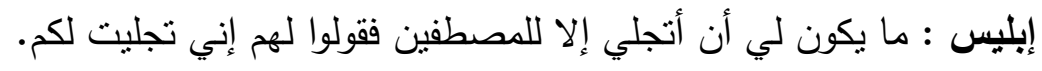
الشيوخ : لن يصدقوا دعوانا حتي يروك كما رأيناك.

$$
\text { البليس : البيوخ : (في اهتمام أن بروني في الذهب. الذهب. }
$$

إبليس : نعم ، بلغوهم أني قد جإي) الذهلت من نعمتي عليهم أن أتجسد لهم في هذا المعدن النفيس فليحرصوا علي جمعه لتكون لهم القوة والسلطان.

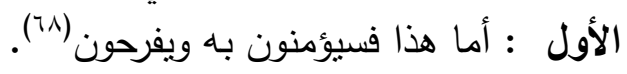
وفي موضع آخر من نفس المسرحية يبين لنا علي أحمد باكثير مدي الحئ الحب الذبي الذي يكنه الإسرئيليات للذهب فهم يعبدون الذهب من دون الله، بل سيعبدون الذهب اليوم وغدًا، بل إلي لئي

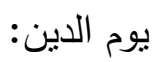
إبليس: إنما ندموا علي الذهب الذي كانوا له عابدين وسيعبدونه حيثما وجدوه إلي يوم

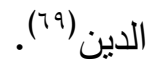

وتري الباحثة أن باكثير متأثر في الجزئية السابقة من مسرحيته بقصة موسي عليه السلام

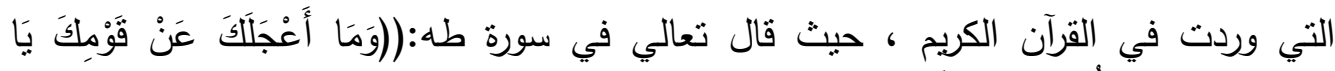

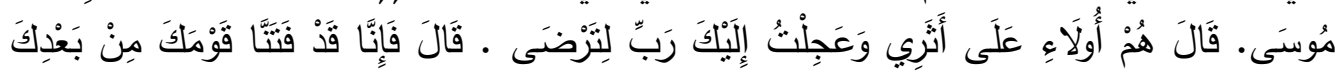

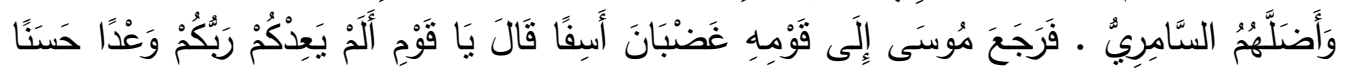




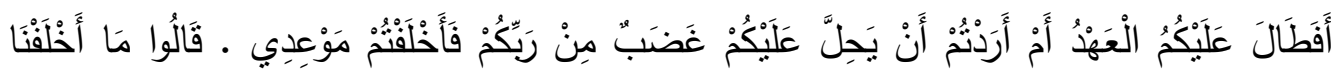

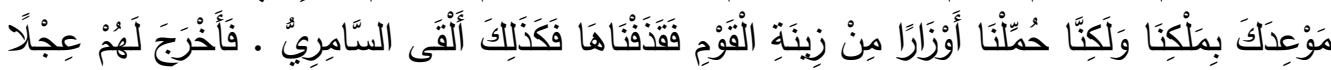

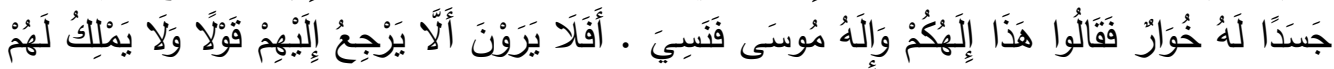

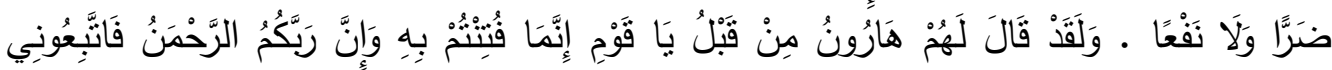

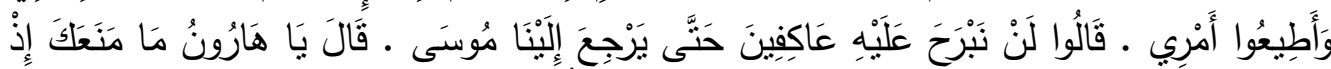

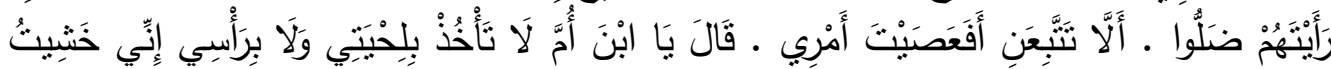

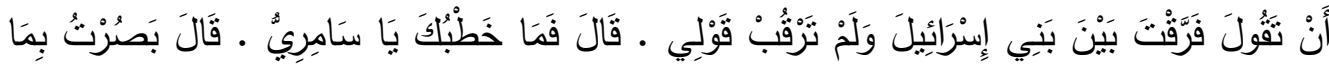

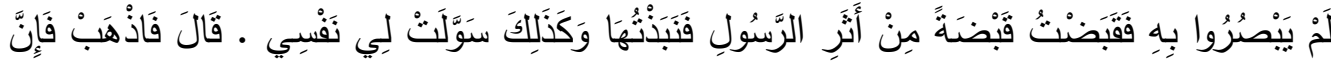

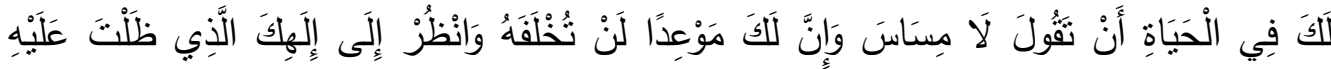

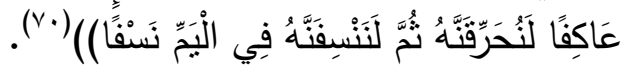

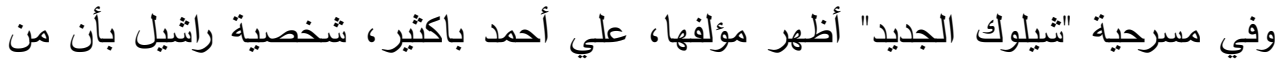

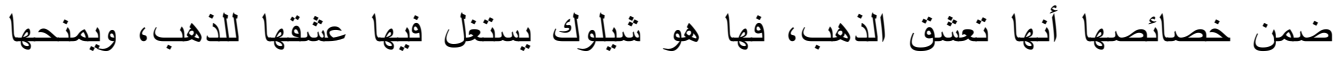
بعضًا منه مقابل أن تتفذ له أغراضه الدنئئة

شيلوك : لا تبتئسي يا بنتي؛ سأعوضك عما لحقلك من الضرر • (يفتح أحد أدراج مكتبه

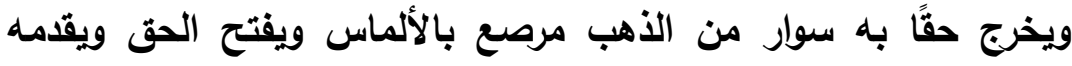

لراثشيل) هل يعجبك هذا السوار يا راشثيل.

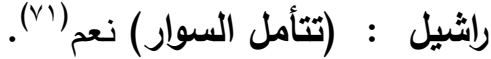

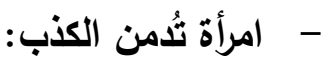

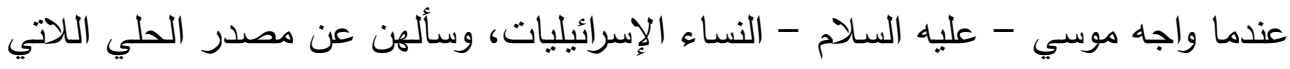

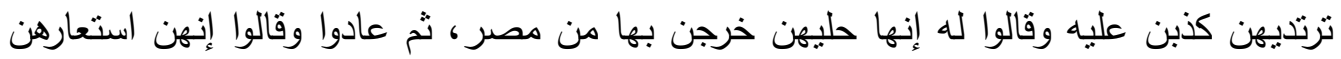

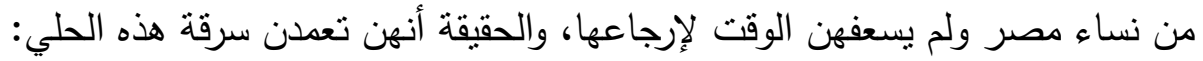

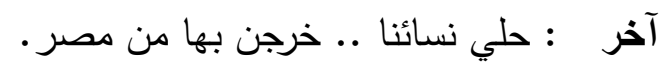

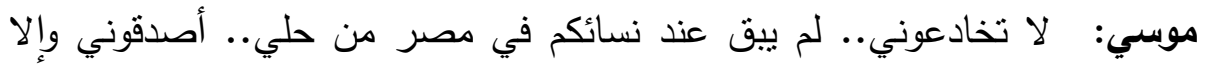
فوالذي أنا ذاهب إلي ميقاته لأفعلن بكم الأفاعيل.

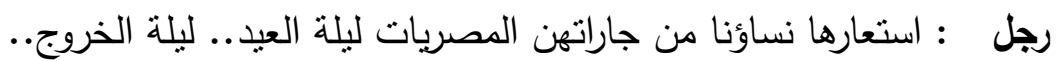
امرأة : وأعجلنا الخروج فلم نتمكن من إعادنانها إنها إليهن.

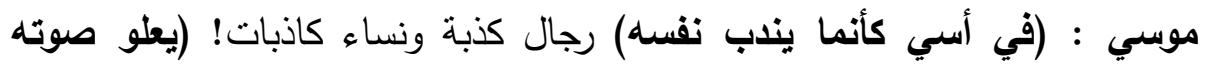

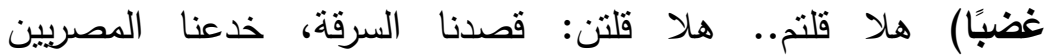

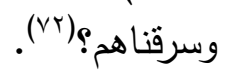

وفي مسرحية "ثيلوك الجديد" نجد أن راشيل تكذب علي خطيبها "إلباهو"، وتقول له - إنها

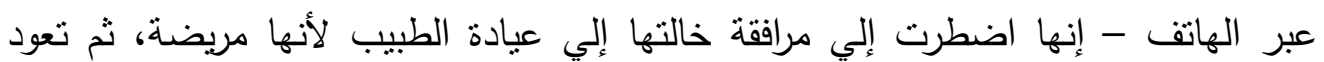


وتقول لله إنها شعرت بفتور شديد فلزمت الفراش؛ في الوقت التي كانت موجودة فيه مع صديقها خليل في بيت عبد الله الفياض: فئن

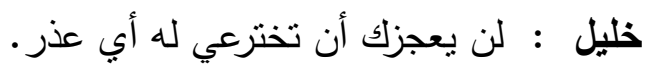

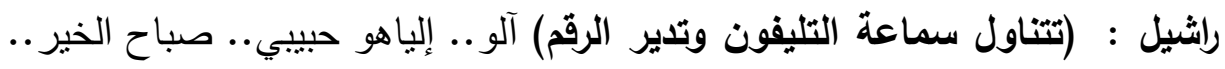

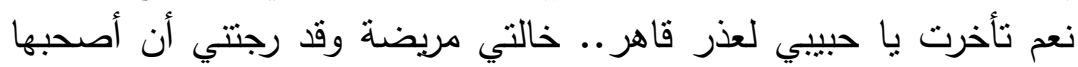

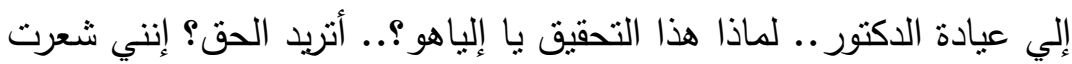

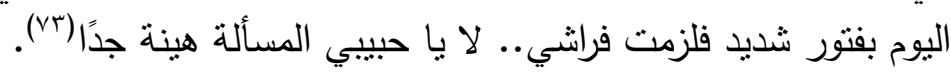

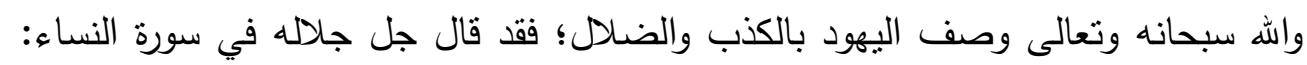

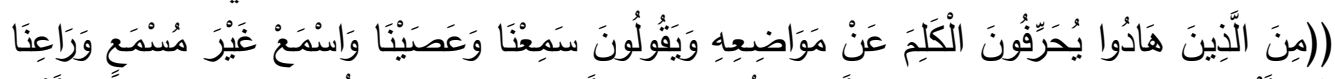

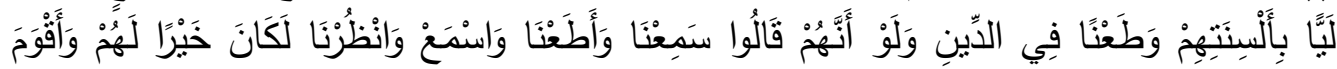

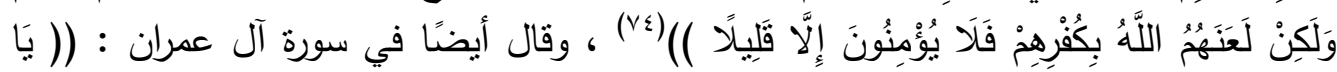

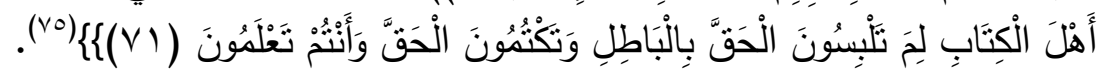

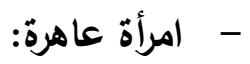

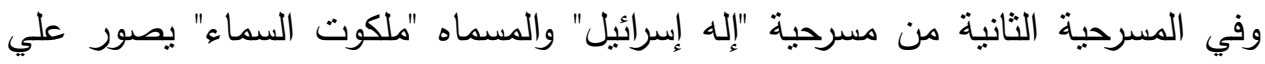

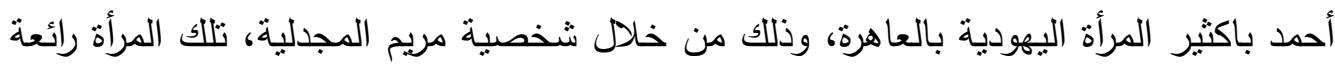

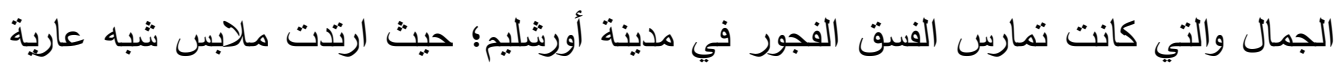

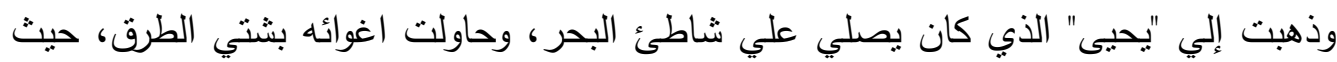

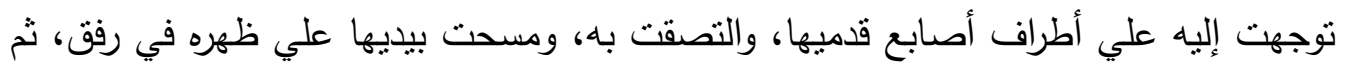

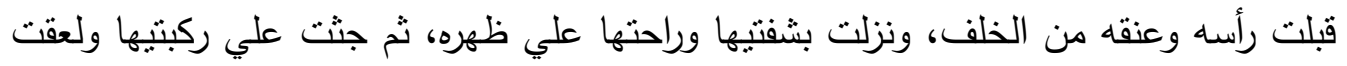

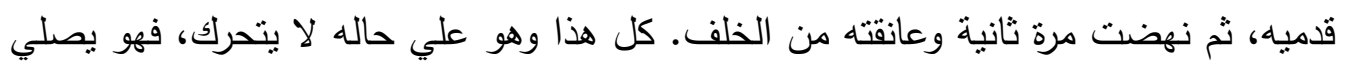

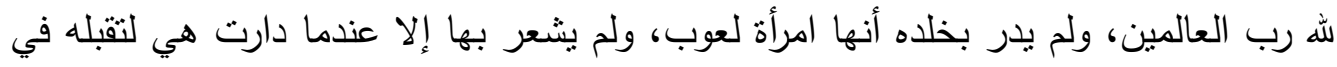

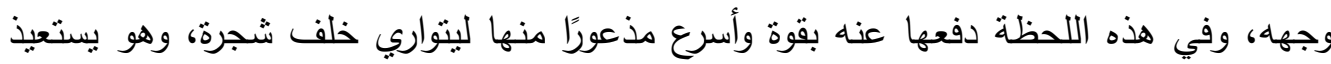

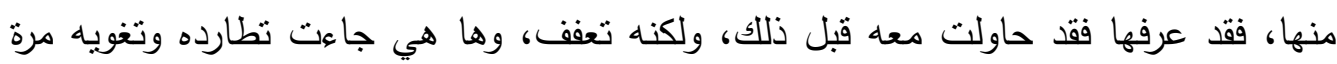

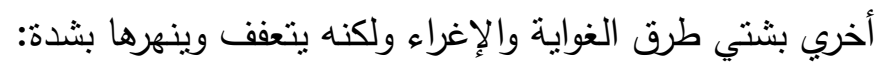

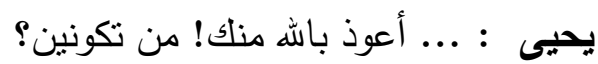

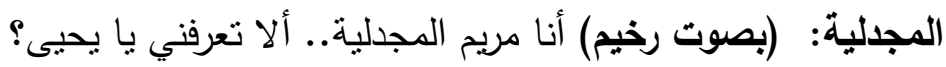

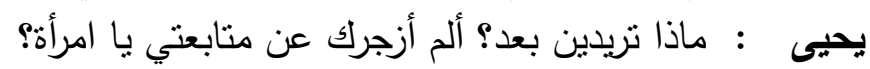

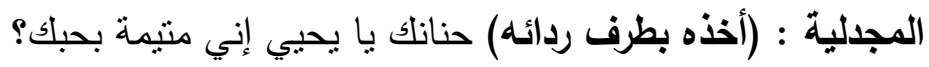

يحيي : ويلك توبي إلي ربك با خاطئة! المجدلية: سأتوب با يحيى بعد أن أفوز بعطفك.

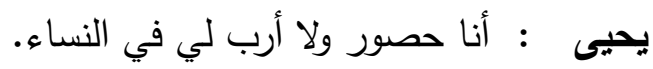
المجدلية: لكني أنا با يحيى لي أرب فيك ليكاء 


$$
\begin{aligned}
& \text { يحيى : : يا حبالة الثيطان ابتعدي عني! } \\
& \text { المجدلية: لن أبتعد عنك حتي تعدني. }
\end{aligned}
$$

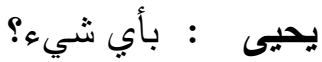

المجلية: بأن تزور بيتي. إنك تعرف بيتي. لا أحد يجهل بيت المجدلية في أورشليم.

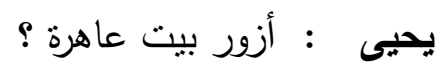

المجلية: سامحك الله يا يحيى. أنظنني منديلا لكل شفة؟؟ إنما يتودد لي عِلية العِلية من

$$
\text { الشيوخ والرؤساء. }
$$

يحيى : : هؤلاء حطب جهنم.

المجدلية: حطب جهنم!

$$
\text { يحيى : أجل اذهبي إليهم واغربي عني! }
$$

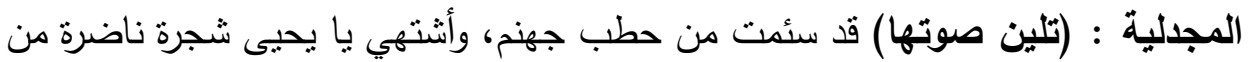

\section{الجنة!}

يحيى : الجنة ليست للخاطئين والخاطئات.

المجلية: لعلي أتوب يا يحيى علي يديك! تعال با حبيبي إلي بيتي في ظلام الليل

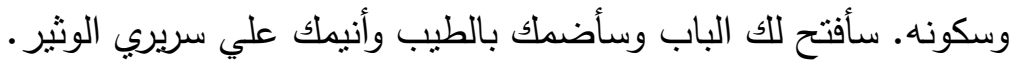

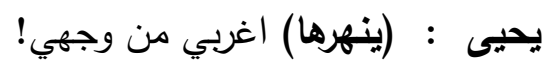

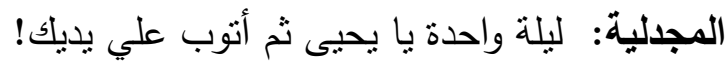

$$
\text { يحيى : : إليك عني يا فاجرة! (VT) }
$$

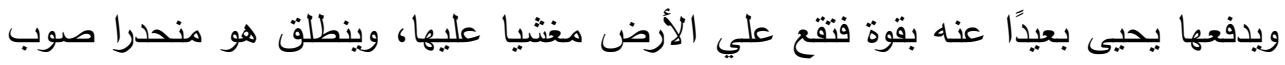

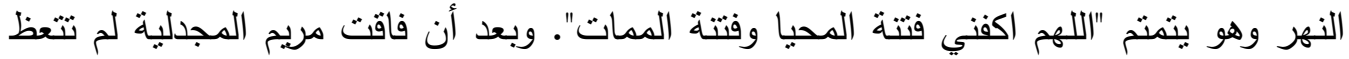

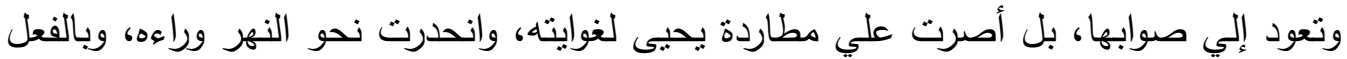

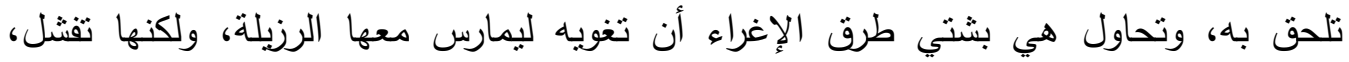

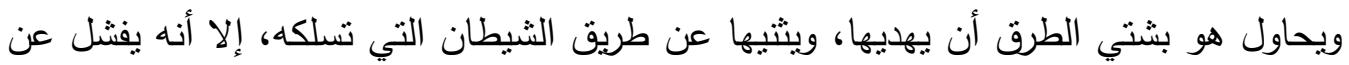

يحيى : ماذا تريدين بعد يا غاوية؟ إن لم تكفي عن سوء عملك أغرقتك في هذا النهر.

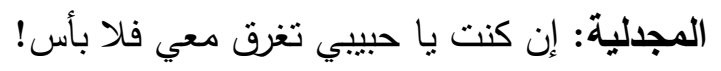

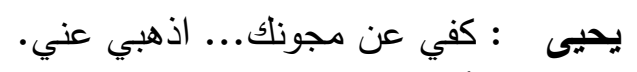

المجدلية: ألا تطهرني يا يحيى كما طهرت الأخرين؟ أليس لي أن أنطهر متلكه؟ يحيى : بلي، عسي الله أن يتوب عليك ويطهرك من هذا الرجس، الرجي، أعطيني رأسك.

$$
\text { المجيى : أسلة: رأسي وجسدي وكلي! }
$$


المجدلية: قد مسحت علي رأسي يا يحيى فامسح كذلك علي صدري!

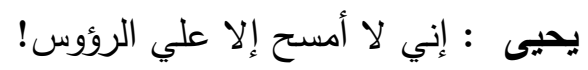

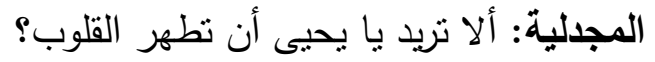
يحيى : بلي.

المجلية: فأين القلوب يا يحيى إلا في الصدور؟ يحيى : إني أرش الماء علي الصدر وعلي سائر الجسئ الجسد.

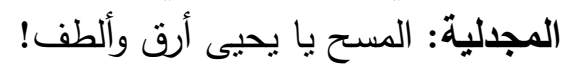

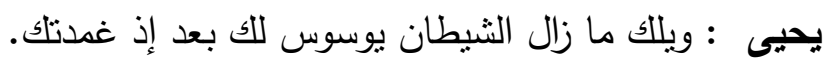
المجلية: إذن فغدني يا يحيى مرة ثانية. يحيى : هاتي رأسك (يغمدها مرة ثانية)

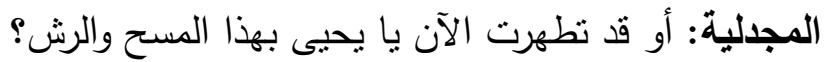

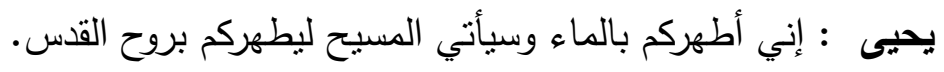

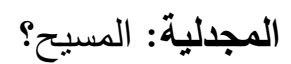
يحيى : المسيح الذي يفتح لكم ملكوت السماء.

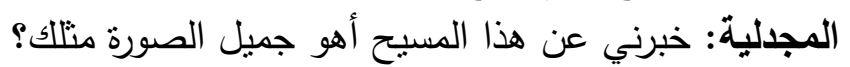
يحيى : الثيطان ما زال يوسوس للك، اذهبي عني. المجدلية: بل من حقي عليك أن تعمدني مرة ثالثة.

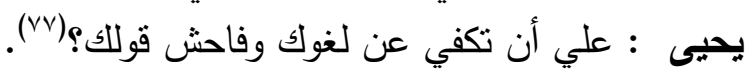

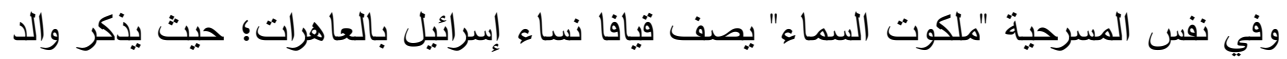
زوجته بأنه كان يضاجع العاهرات الإسرائيليات: قيافا : ألم تكن للك أنت خلائل من الإسرائيليات وغير الإسرائيليات تخلو بهن في

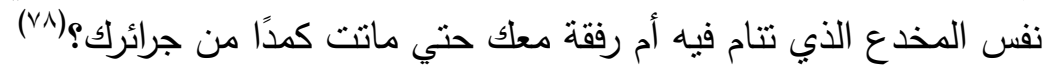

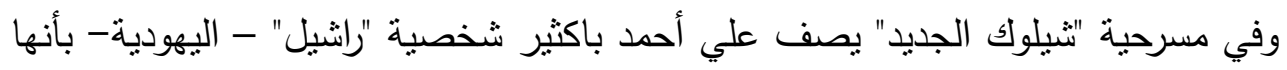

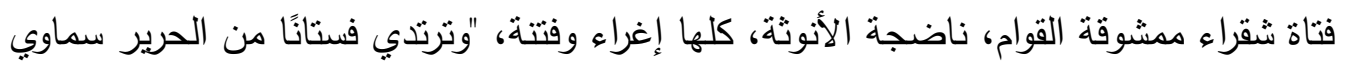

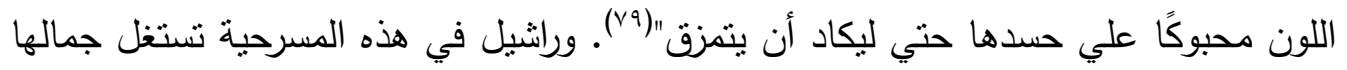

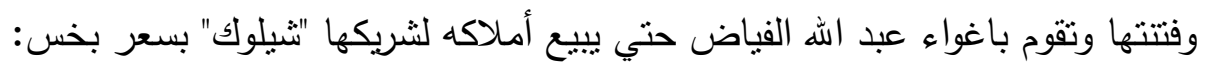

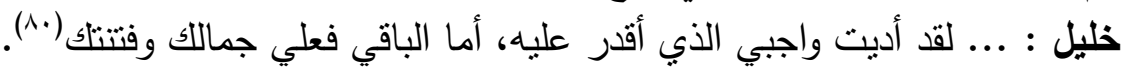

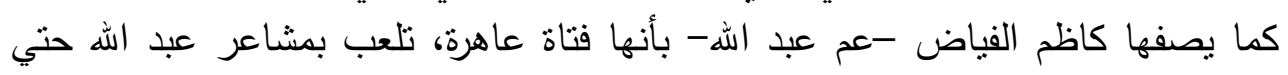

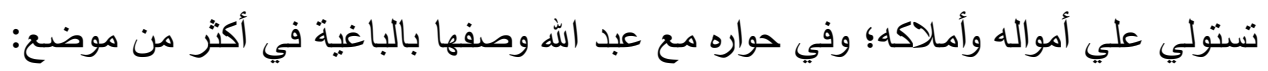

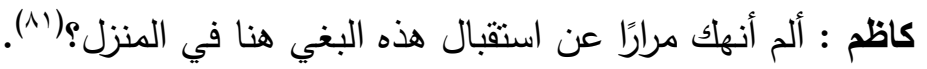


كاظم : أيمس حريتك أن أنهاك عن هذه البخي اليهودية الخطرة علي سمعتلك وعلي أملاكك؟ب(Nr).

كاظم : ... وإلا فقل لي أين الألف والخمسمائة جنيه التي سحبتها مني لتؤسس بها

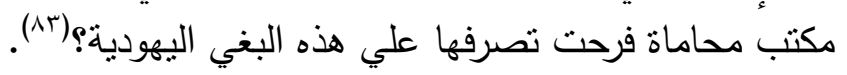

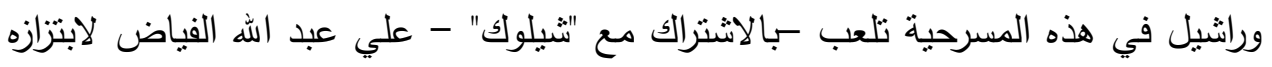

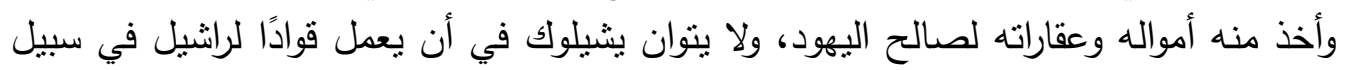

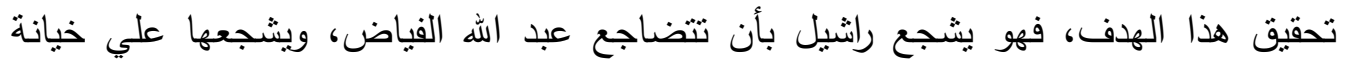

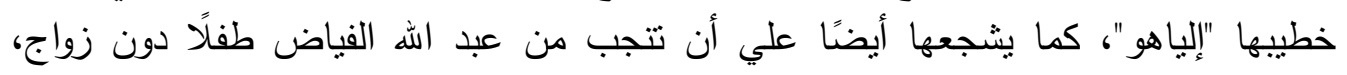

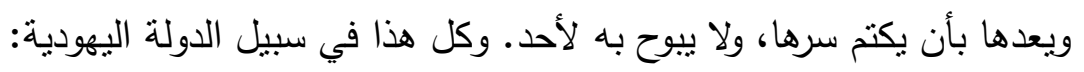

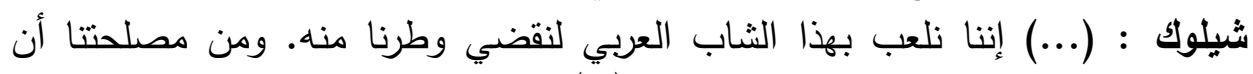

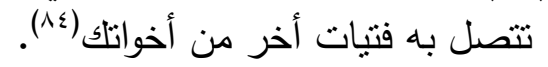

$$
\text { راشثيل : أشعر بأعراض... }
$$

شيلوك : ها. فهمت. هوني عليك با بنتي فهو أمر بسيط

شيلوك : أنخافين أن بدري إلياهو بالأمر؟ ثقي أنه لا بعلم أحد غيري وغيرك

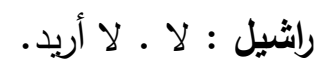

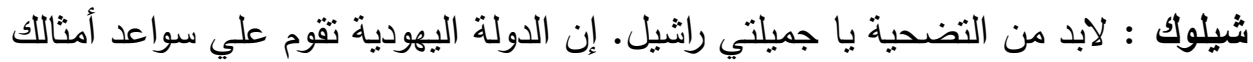
من المضحيات المخلصات(10).

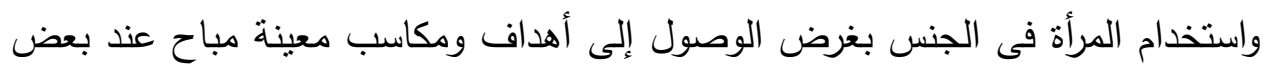
رجال الدين اليهودي، حيث "نشرت صحيفة يديعوت أحرونوت الإسرائيلية الواسعة الإنتشار

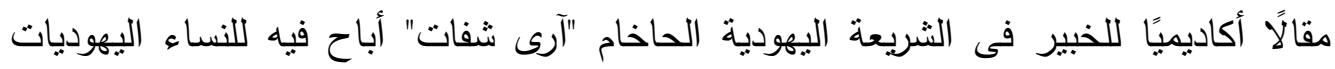

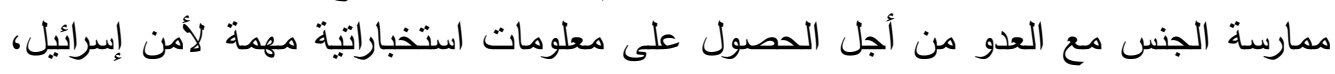

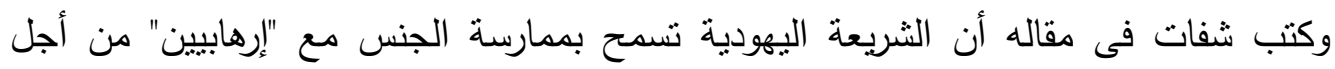

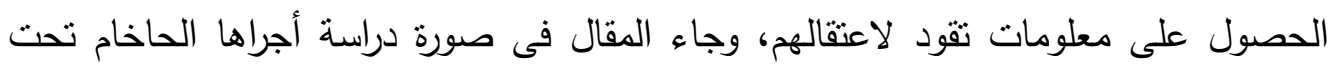

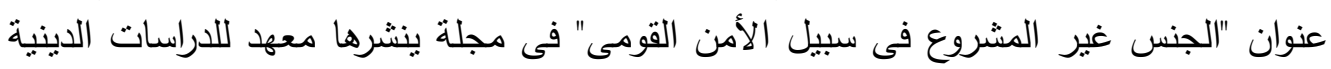

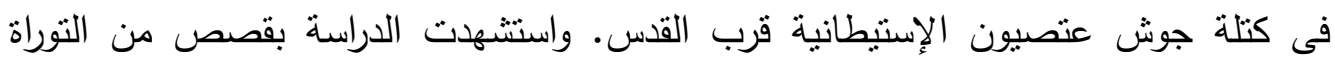
تحدثت عن نساء أغوين مقاتلين من الأعداء من أجل الحصول على على ملى معلومات قيمة، مضيفًا

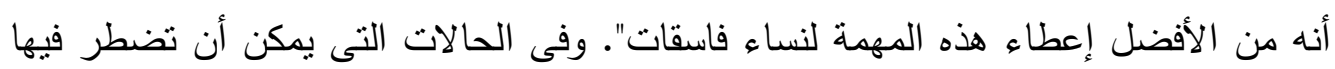

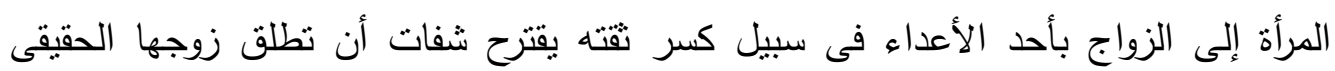

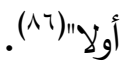

وعلي عكس هذه الصورة يُظهر علي أحمد باكثير المرأة العربية في مسرحه، ففي مسرحيته التوراة الضائعة، تستحي المرأة العربية العجوز أن ترفع ذيل ثوبها عن المن الماء، وهي تعبر النهر - 
حتي لا يظهر شيء من جسدها، وهذا الأمر بطبيعة الحال ضد مبادئ العهر والابتذال التي هي تعتنقها المرأة اليهودية؛ حيث نري كوهين يسخر من هذه العاه العجوز التي عبرت النهر بثنيابها:

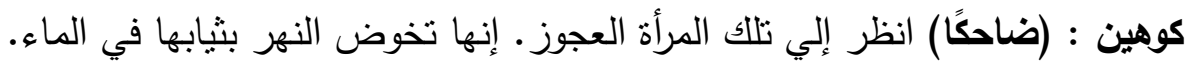

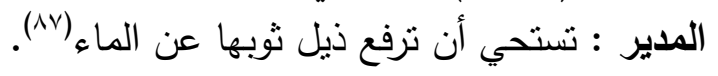

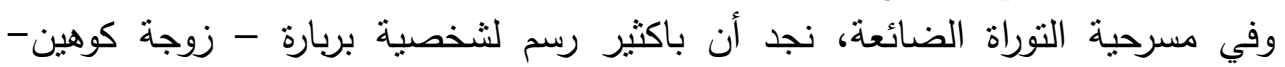

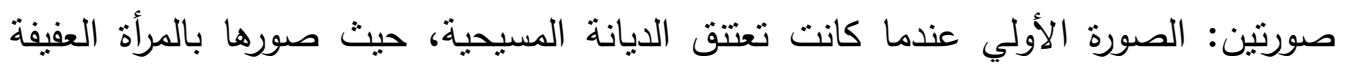

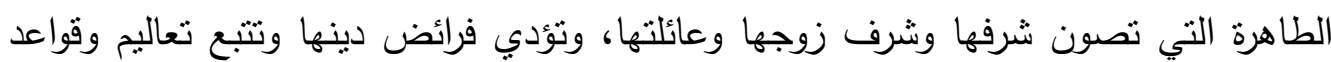

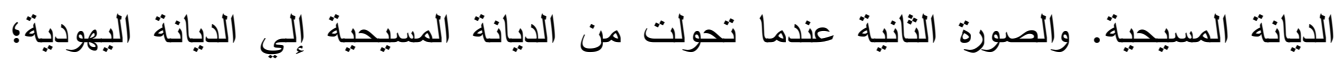

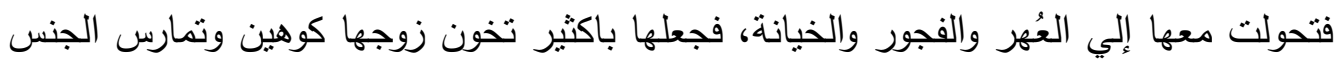

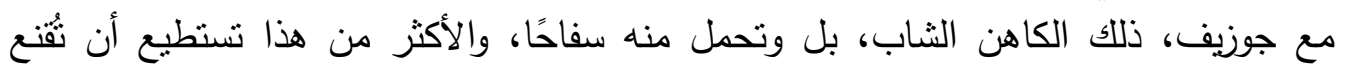

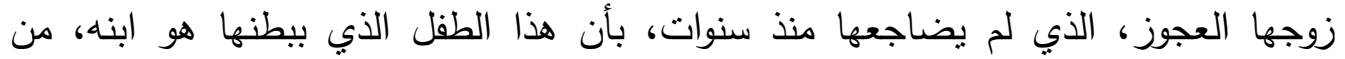

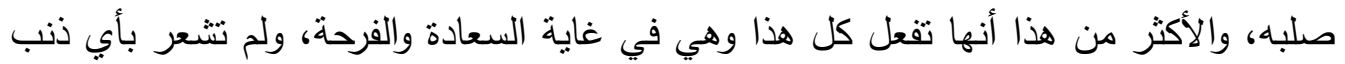

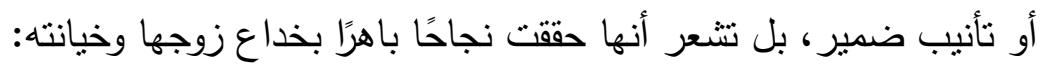
بريارة : (تتراقص فرحًا) هنئيني يا آنا. آنا : أهنئك بماذا؟ بالخطيئة؟

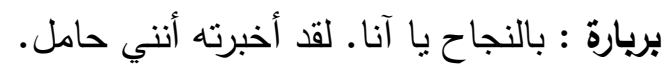

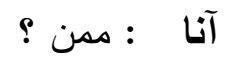$$
\text { بريارة : منه . آنا }
$$

آنا : بريارة : من ذلك الكاهن؟

$$
\begin{aligned}
& \text { بريارة : من زوجي نفسه . آنا } \\
& \text { آنا : بريارة : وصدق ؟ }
\end{aligned}
$$

بريارة : مبكتها له با أنا.

\section{(...)}

آنا : يا لآلام المسيح! أبعد الطهارة والنقاء وصلوات الآحاد في الكنبسة وزيارة الأماكن

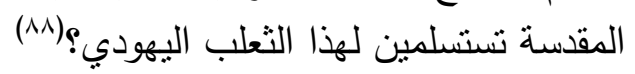

وفي هذا السياق يصفها جوزيف بأنها يهودية أصيلة، تعشق ممارسة الجنس:

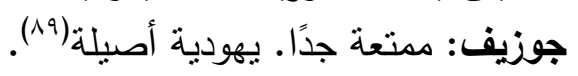

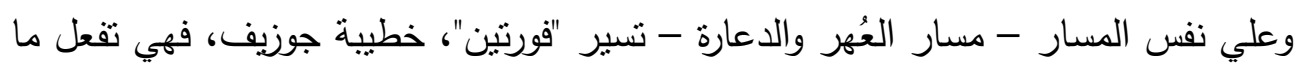

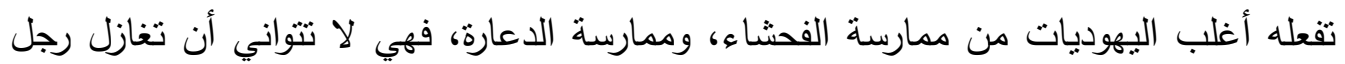

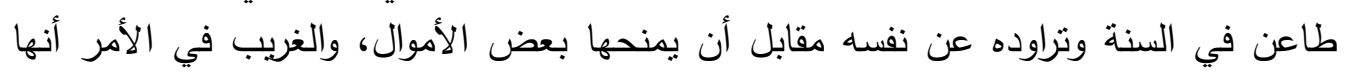


تفعل ذلك بعلم خطيبها جوزيف، بل الأكثر من هذا أن جوزيف نفسه يشجع كوهين علي أن

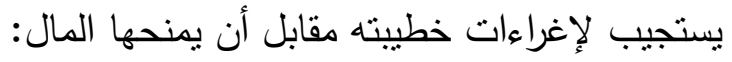
جوزيف : لا يُعقل أن تتساها. إنكانك غازلتها. كوهين : غازلتها؟

جوزيف : ليس في ذلك أي بأس. أظنها أعطنك عنوانها ورقم تليفونها.

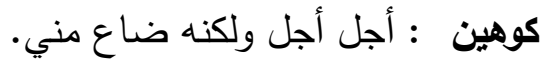
جوزيف : خذ هذه بطاقتها لعلك تريد يومًا أن تشجع صندئ مندوقها. $(\ldots)$

كوهين : (يتمتم) الواقع أنني ما غازلتها.. هي التي غازلتني... أه .. ليت الثباب

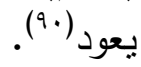

كما أن فورتين حامل من جوزيف وهما لم يتزوجا بعد:

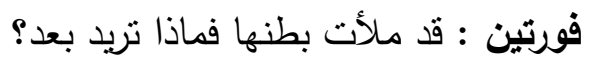

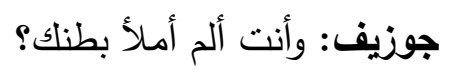
فورتين : وهجرتتي بعد ذلك وتركتتي لهذا العجوز .

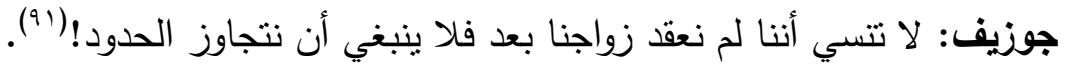

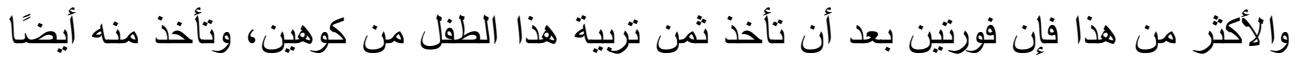

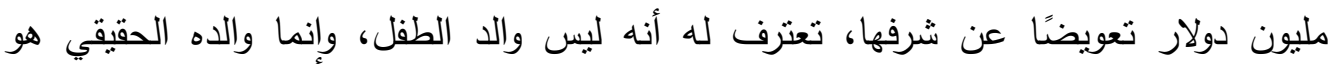

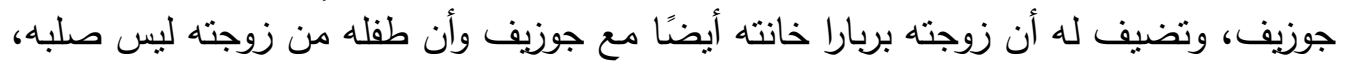
وإنما من صلب جوزيف أيضًا: جوزيف: ليشع وبنجامين ليسا من صلبك.

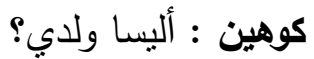
جوزيف: ولدالك بالتبني فقط؟ كوهين : فمن أبوهما إذن : ولن بالن جوزيف: أنا أبوهما. كوهين : أيها الكاهن الكذاب. أبراب. جوزيف: سل المرأثين إن شئت.

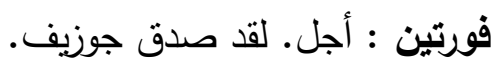
كوهين : كذبت أيها الداعرة. فورتين: لا تشتمني. سل امرأتك لتؤكد للك هذه الحقيقة، لقد كانت تتافسني في 
كما يصل العُهر وممارسة الرذيلة مداه في هذه المسرحية؛ حيث تمارس المرأة اليهودية الرذيلة

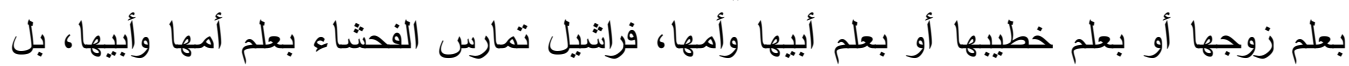

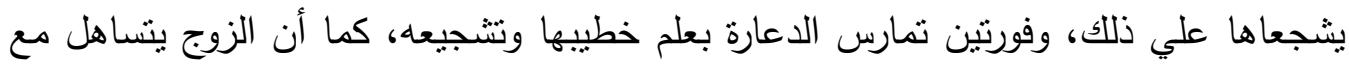

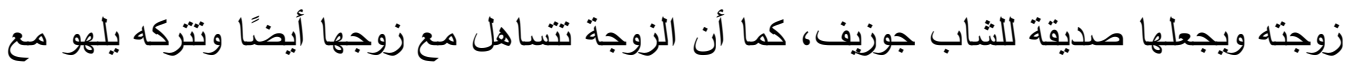
فورنين خطيبة جوزيف:

فورتين : معلوم ـ أنت مطمئن من ناحيته لأنه هرم متهدم.

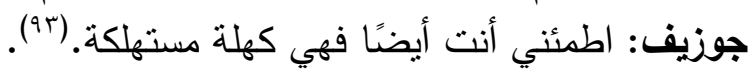
راشيل : أين أذهب يا أبي؟ أنب أبئ

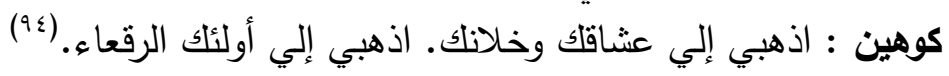

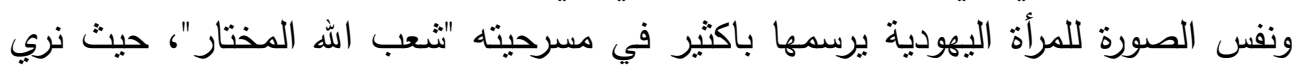

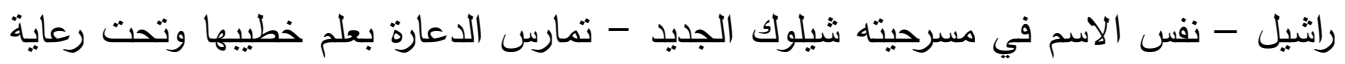

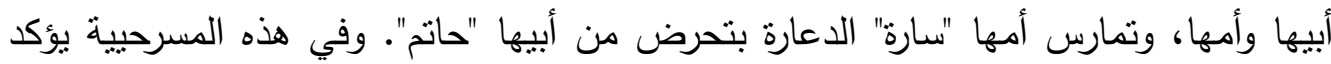

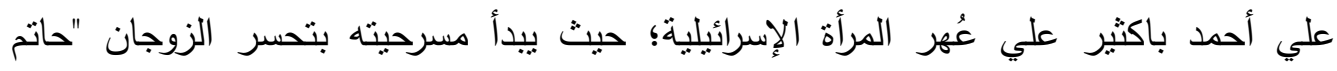

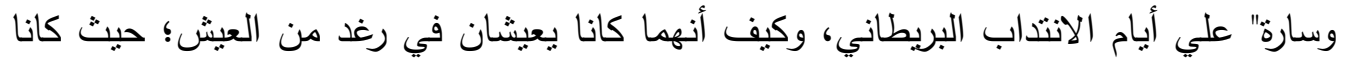

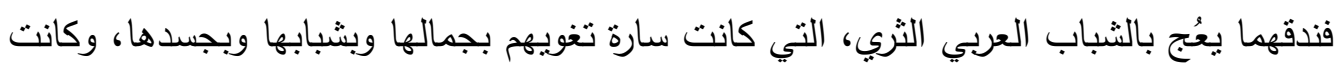

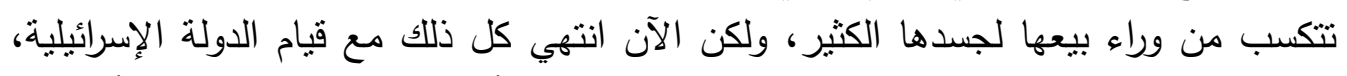

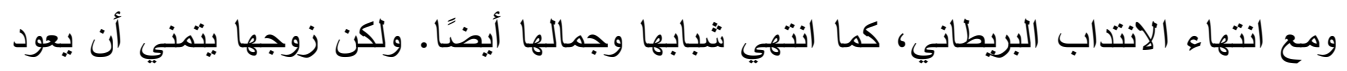

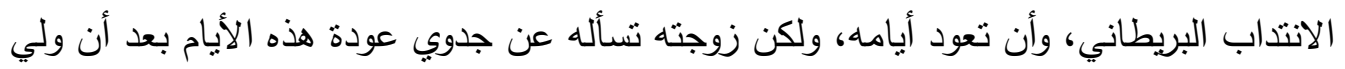

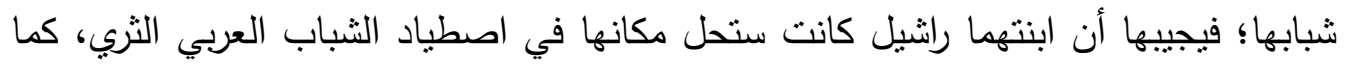

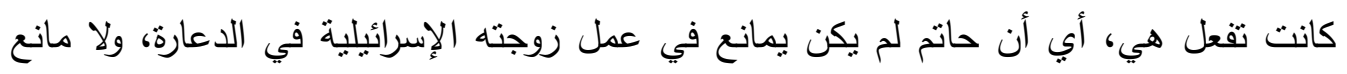

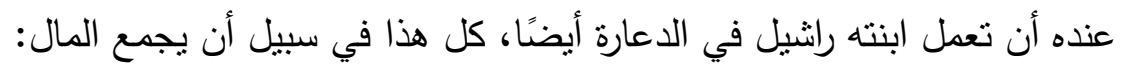

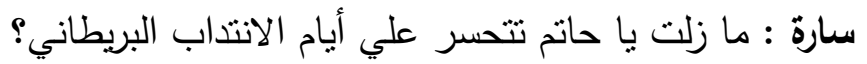

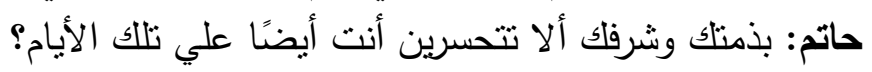

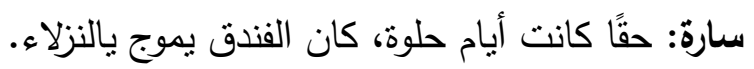
حاتم: وأي نزلاء من شبان ائمان العرب الوارثين.

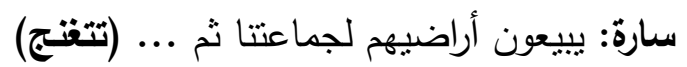

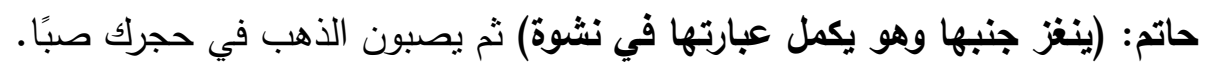
سارة: راحت تلك الأيام يا عزيزي وراح معها شبات شيابي. حاتم: لو بقيت تلك الأيام ماراح شبابك.

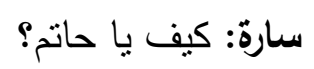
حاتم: كانت البركة في ابنتنا راشيل(90) 
وفي هذه المسرحية أيضًا "شعب الله المختار" لا تتواني راتشيل في أن تتهض من جوار

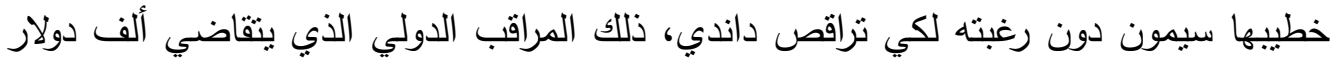

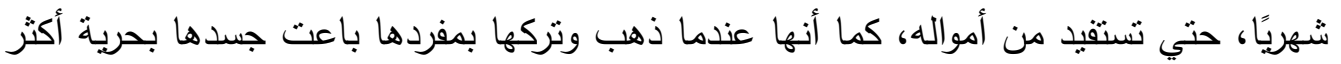

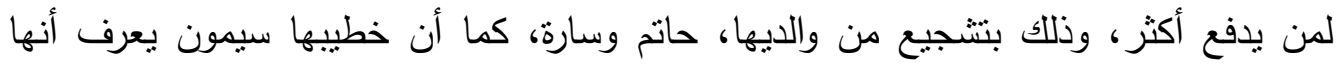

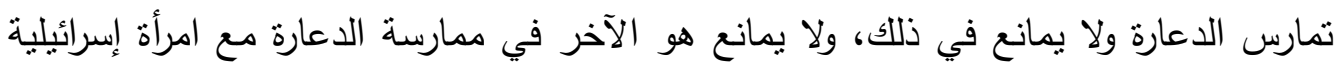

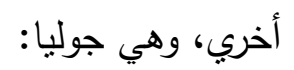

راثيل : (تنهض وتصلح شعرها) عن إذنك با سيمون.

$$
\text { سيمون: لكن يا راشيل... }
$$

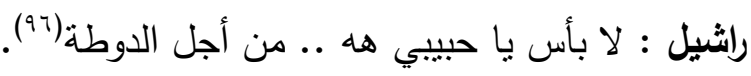

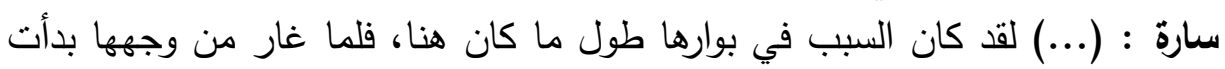

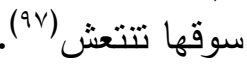
جوليا : (...) أجل هو جاء وحده ليكون علي حريته وأنا جئت وحدي لأكون علي

$$
\text { حريتي. }
$$

سيمون: عجبًا! إنها تغازلني

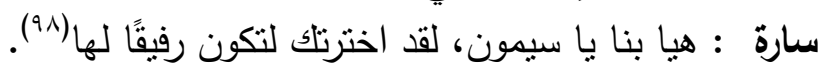
راشيل: عندك إذن أكسير الثباب (في إغراء ودلال) أفلا تعطيني منه شينًاً يا مستر

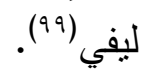

ويؤكد باكثير رؤيته هذه في هذه المسرحية عندما جعل كل فنادق إسرائيل ترفض مبيت أي

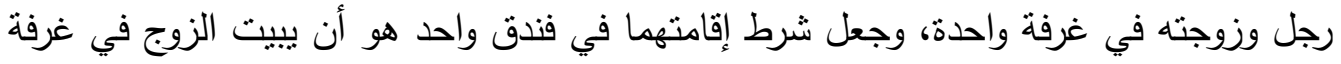

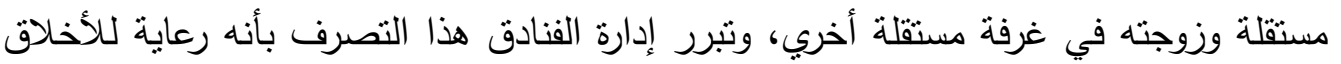

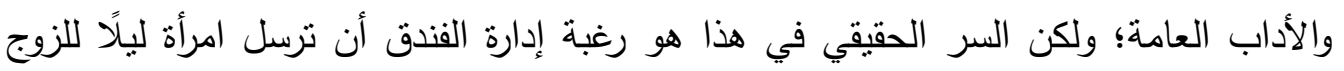

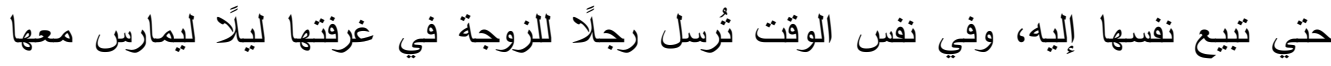

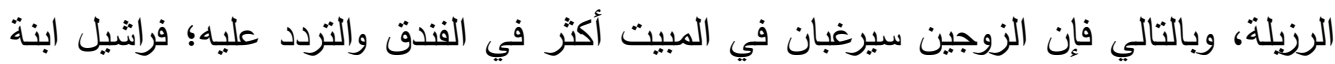

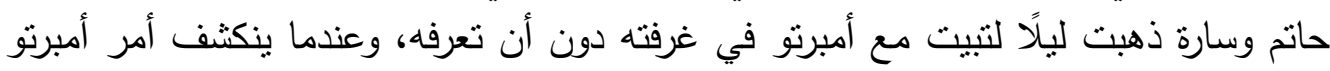

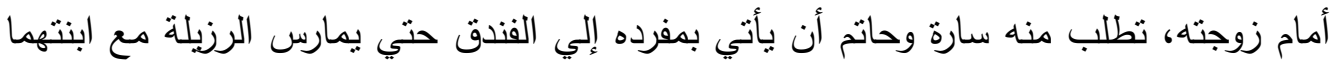

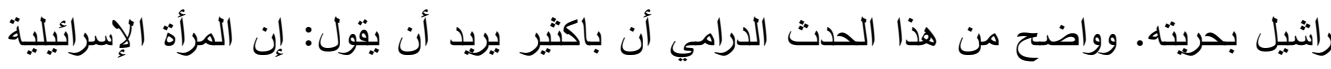
عاهرة، بل إن المجتمع الإسرائيلي كله مجتمع يقوم علي الهي الرزيلة:

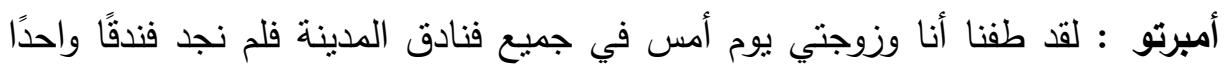

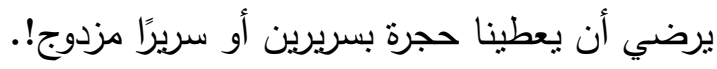
حاتم : هذا ممنوع هنا في تل أبيب 


$$
\text { أمبرتو : ولكنها زوجتي. }
$$

حاتم : ولو... للرجال جناح وللنساء جناح : ولناح

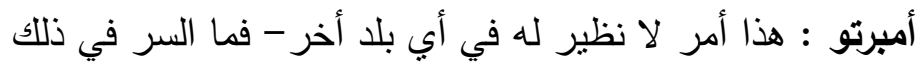

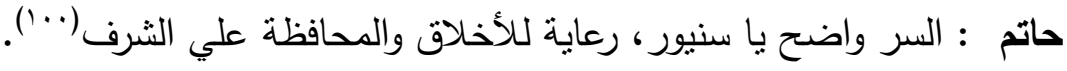
أمبرتو : ... جناح للرجال وجناح للنساء.

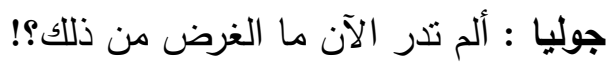
أمبرتو : المحافظة علي الأخلاق. جوليا : أه منك يا خائن، أعجبك الحال لأن هذه الفئ الفتاة تسللت إليك البارحة في

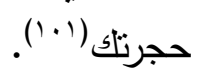

سارة : (...) ستحزن راثنيل كثيرًا لفراقلك.

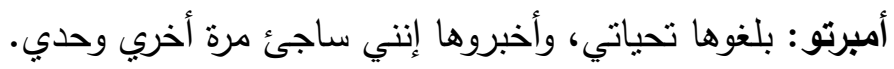

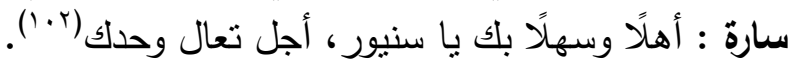

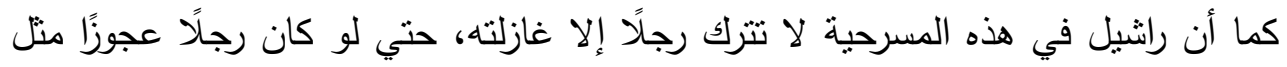

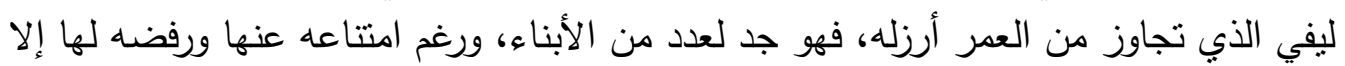

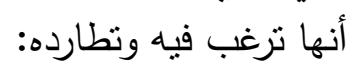

ليفي : ابنتي الكبري متزوجة ولها أبناء. أنا اليوم جد.

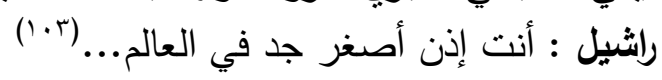

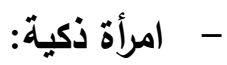

كما يوضح الحوار - من المسرحية الثانية من مسرحية "إله إسرائيل" والمسماه "ملكوت المبه

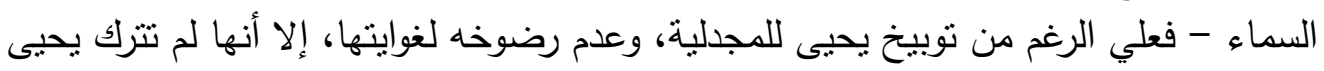

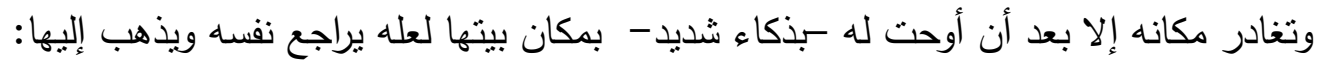

المجدلية: نعم. (يعمدها للمرة الثالثة)

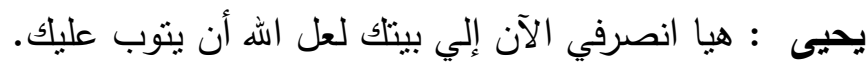

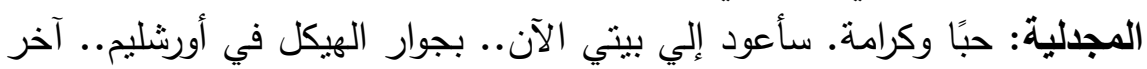

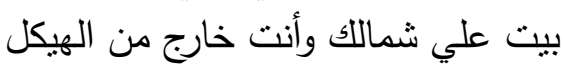

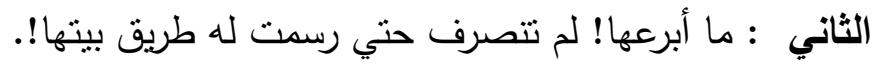

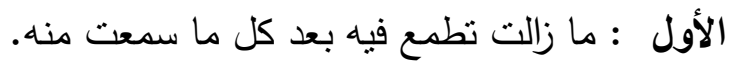

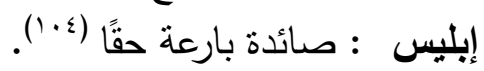

وفي حوار آخر، من نفس المسرحية، يصف قيافا المجدلية بأنها أذكي وأبرع من أذكي الرجال:

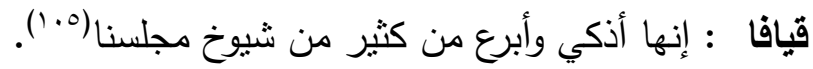


وفي مسرحية التوراة الضائعة، عندما حملت بربارة طفلًا من الكاهن الثاب جوزيف،

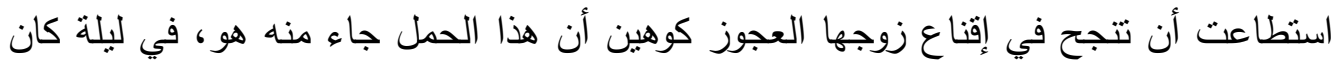

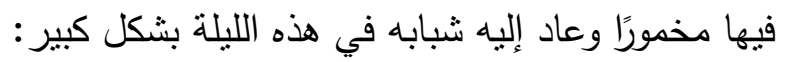
بريارة : أتذكر يا حبيبي تلإد الليلة.. ليلة حملوك مخمورًا من البار؟ كوهين : أجل ليلة الغفران. بريارة : فقد أسعدتتي تلك الليلة بعد انقطاع طويل. كوهين : صحيح؟ أنا لا أتذكر واله.

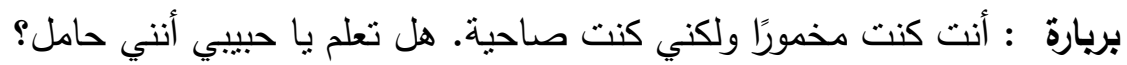

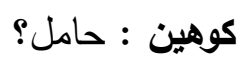

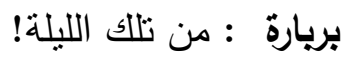

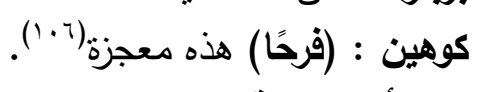
-

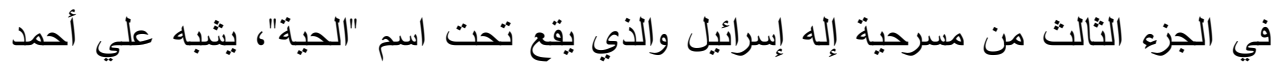

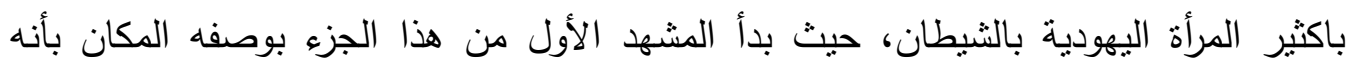

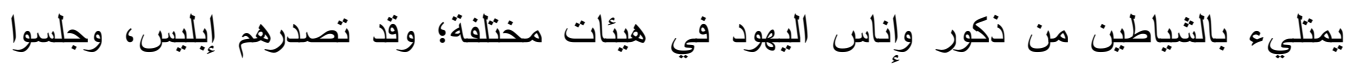

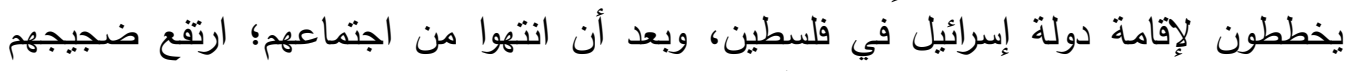

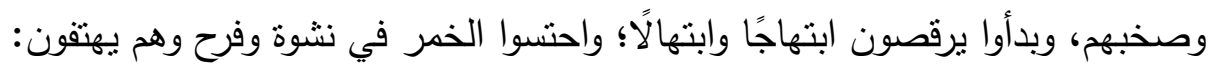

$$
\begin{aligned}
& \text { الجمع : يعيش إبليس العظيم! } \\
& \text { يعيش مولانا الزعيم! }
\end{aligned}
$$

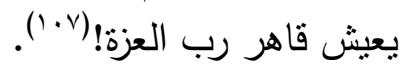

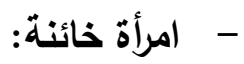

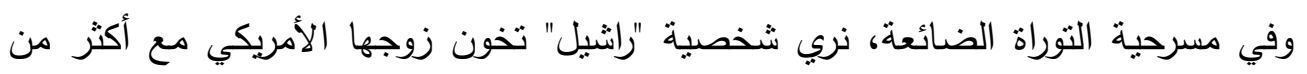

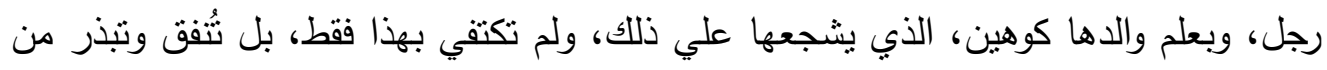
أموال زوجها علي عُشاقها:

راشيل : (...) خذ هذه القبلة مني لتتسي كل شيء (تقبله) ودعني أقدم إليك صديقي.. المستر إيزاك بنيامين.

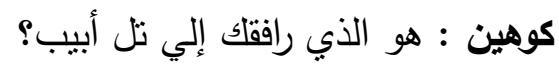

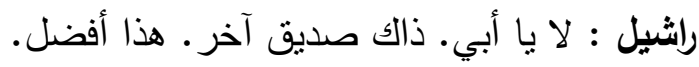
كوهين : أهلًا وسهلًا.

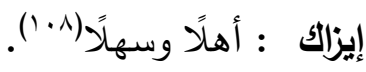
كوهين : ... تريد أن تبذر من فلوس زوجها. هي حرة(1. (1). 
كما تخون راثنيل زوجها، تخون بربارة - أم راثنيل- زوجها ـوالد راثشيل- مع شاب صغير

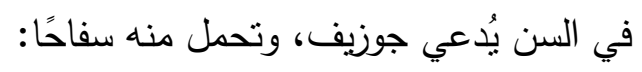

كوهين : ليشع ابنك في ملجأ الهيئة، من أبوه؟

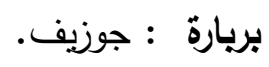

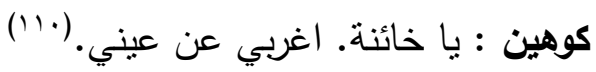

- أمرأة كافرة (لا تعترف بوجود الله):

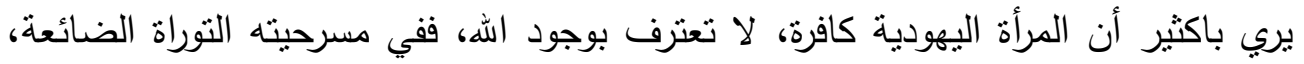

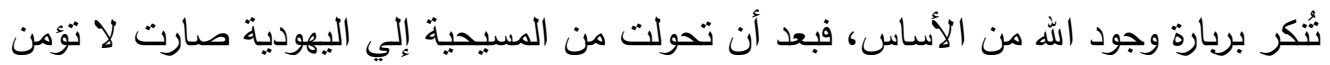

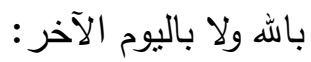

بريارة : اله ـ وأين هو الله يا آنا ؟ أتظنينه يهنم بما بيني وبين زوجي وهو لا يهتم بكل

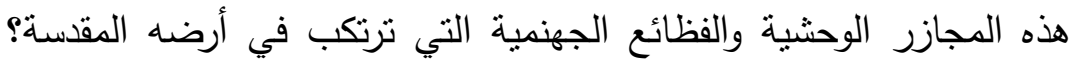

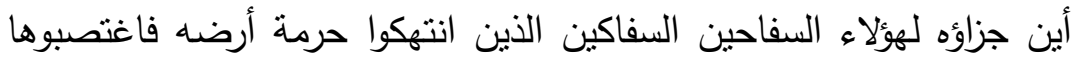

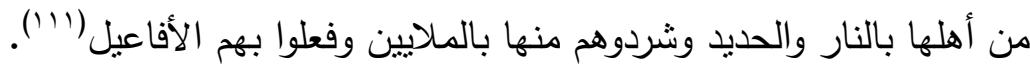

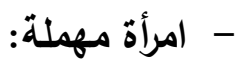

في مسرحيته التوراة الضائعة، نجد راشيل، تُهمل طفلاها إهمالًا شديدًا، وتتركهما للمربية، ونها

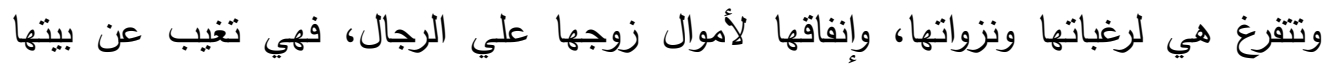

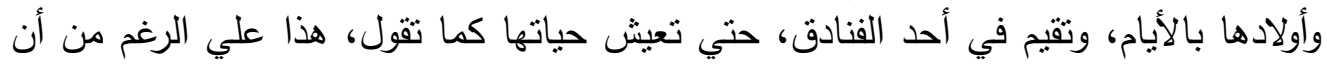

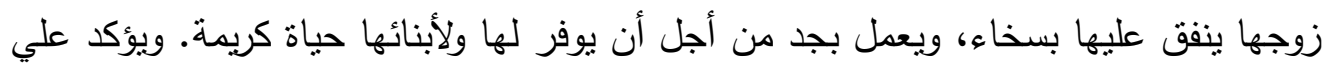

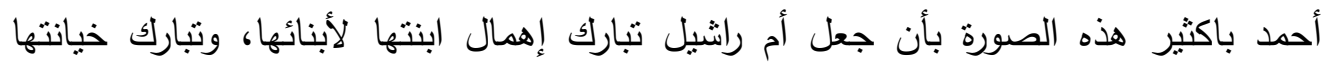

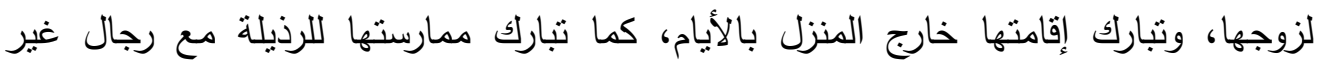

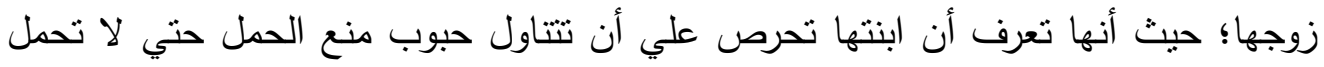
من أحد، وخاصة أن زوجها يعيش في أمريكا، بعيد عنها: أنها: آنا : أنا خائفة يا سيدتي.

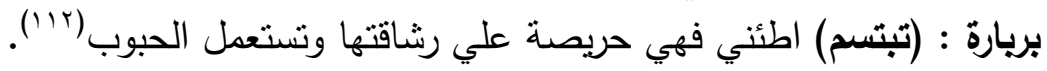

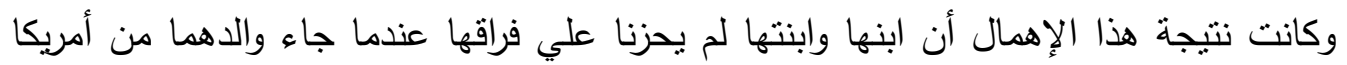

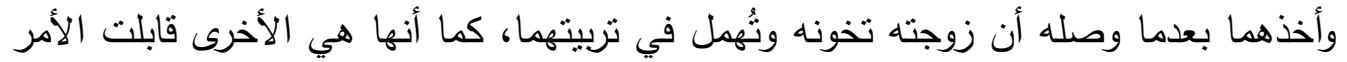
بفتور شديد، وكأنهما ليسا من رحمها: رالثيل : ... آه يا آنا كم أنا إليهما مشتاقة.

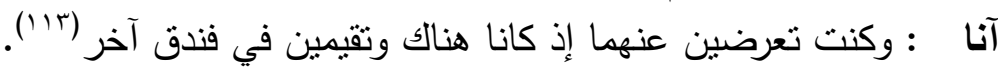
- امرأة غيورة: ورغم أن علي أحمد باكثير وصف المرأة بالعُّر وبالرذيلة إلا أنه جعل الغيرة من سماتها

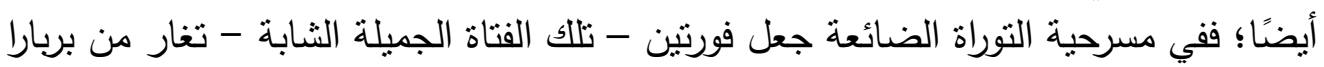


- المرأة العجوز - لعلمها بعلاقة خطيبها بها، وجعل بربارا تغار أيضًا من فورتين، لأن الأخيرة

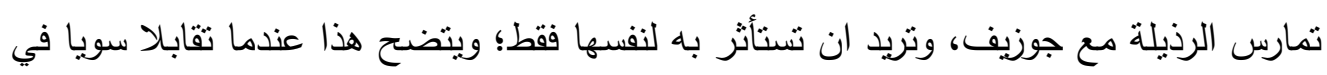

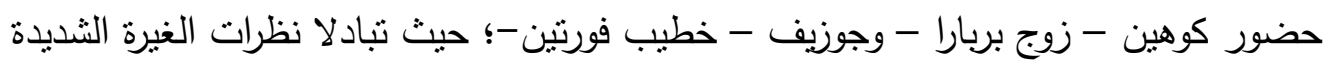

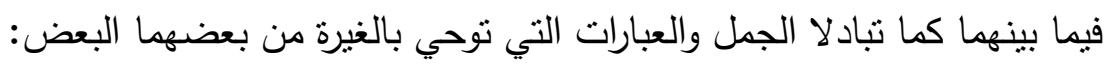
جوزيف : أوهلن ننتهي من هذا الحديث.

(.... ويبدو من أول وهلة أن المرأتين تنظر إحداهما إلي الأخري شزيًا

$$
\text { بالرغم من المجاملات الظاهرة) (؛) ('). }
$$

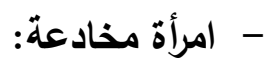
في مسرحية التوراة الضائعة تحمل فورتين طفلًا من خطيبها جوزيف وتدعي - علي غير التها

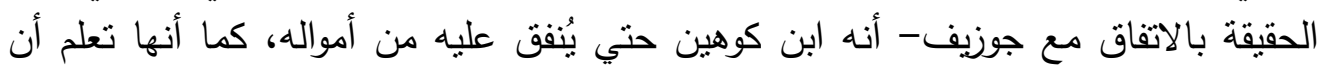

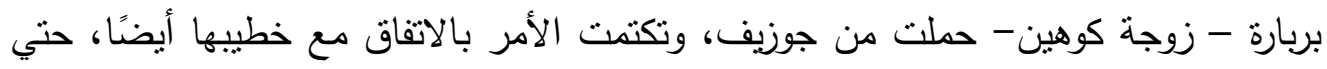
ينفق عليه كوهين باعتباره ابنه:

فورتين : (ملاطفة) ألا تسألني با مستر كوهين عن ابنتا بنجامين ؟

$$
\text { كوهين : هيه كيف حاله ؟ }
$$

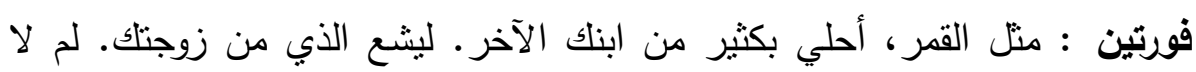

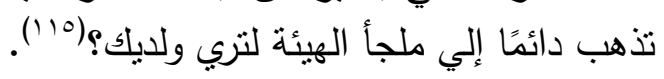

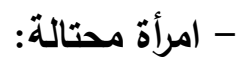

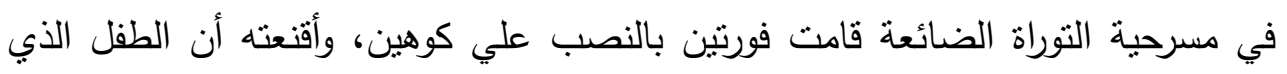

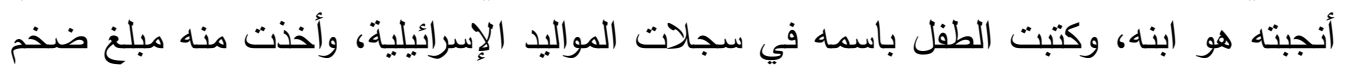

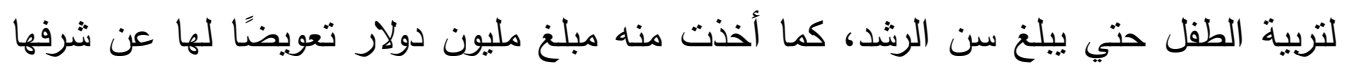

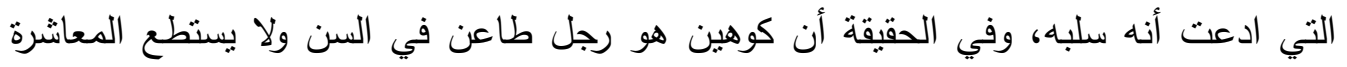

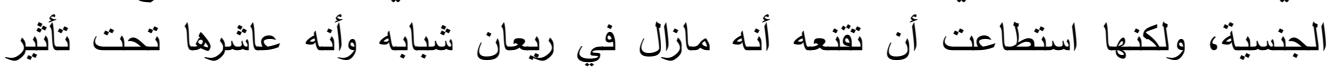

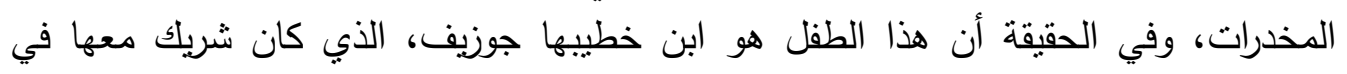

$$
\begin{aligned}
& \text { النصب علي كوهين: } \\
& \text { كوهين : : تعويض : } \\
& \text { جوزيف : لا يستحق شرفها تعويضًا با مستر كوهين؟ }
\end{aligned}
$$$$
\text { كوهين : لقد كنت أغدق عليها الهدايا والمنح المالية. }
$$

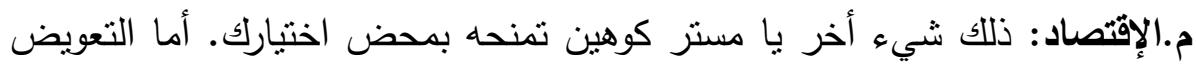

فحق لها عليك.

$$
\text { كوهين : كر؟ }
$$

جوزيف : مليون دولار.(1/7) 


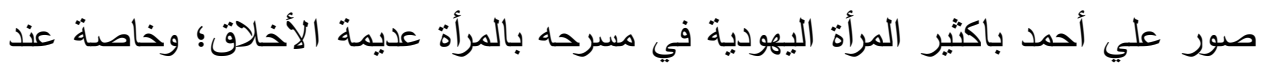

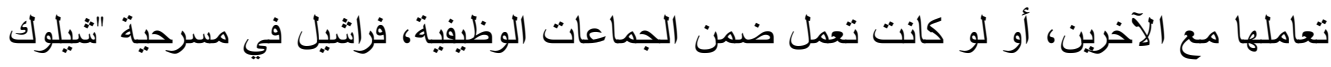

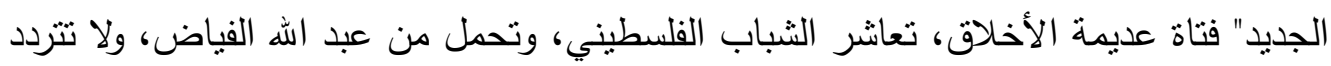

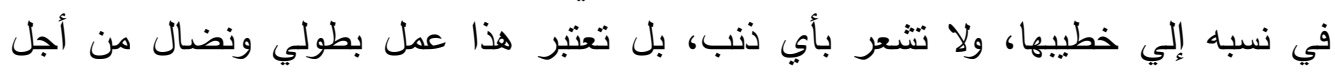

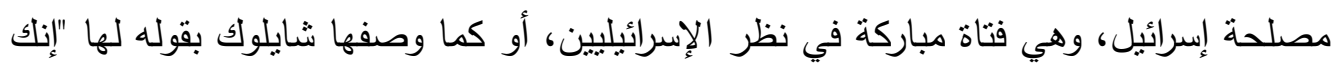

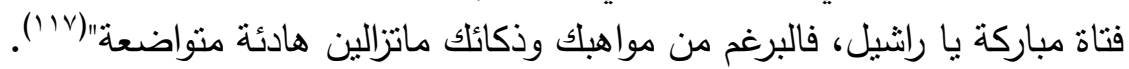

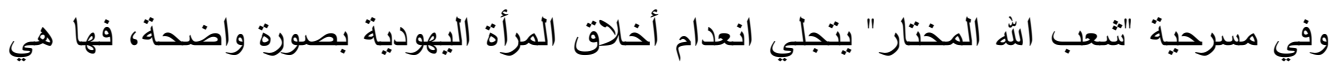

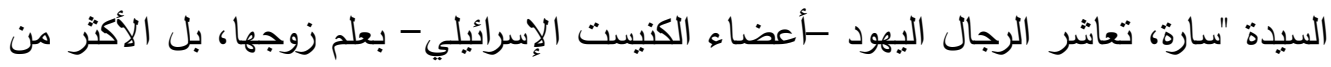

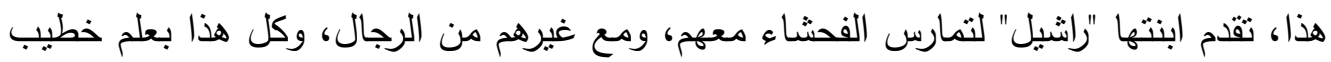

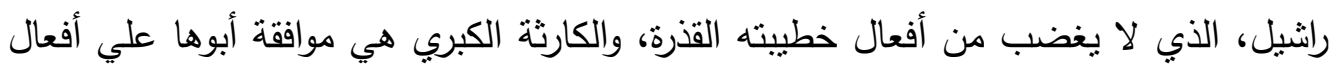

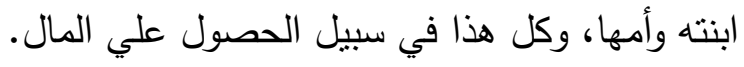
سارة : إن أردت الحق فقد سمعته البارحة من مسيو كوهين.

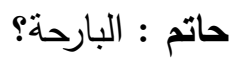

سارة : نعم.

حاتم : أين؟ سارة : (تتعلثم) في في . . حجرته. حاتم : ولكنك لم تخبريني. سارة : قد أخبرتك الساعة.

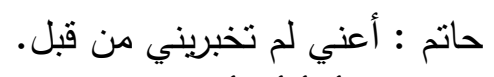

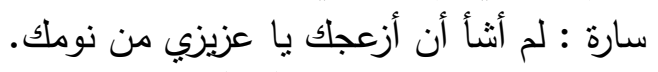

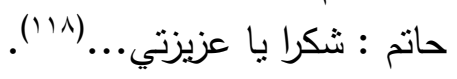

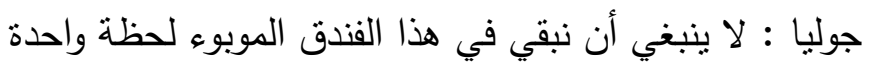

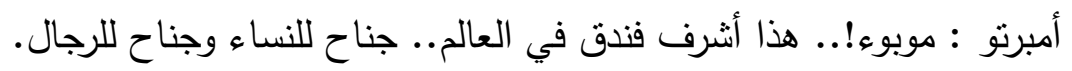

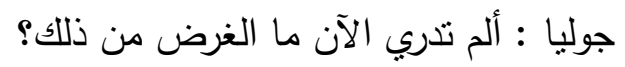
أمبرتو : المحافظة علي الأخلاق طبعًا. جوليا : آه منك يا خائن.. أعجبك الحال لأن هذه الفئا. الفتاة تسللت إليك البارحة في حجرتلك

(تشعر راشيل أن السنيورة تثير إليها فتنسل خارجة)

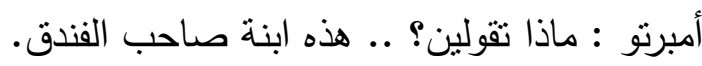

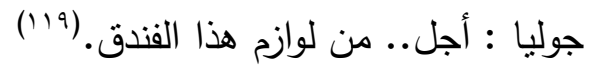




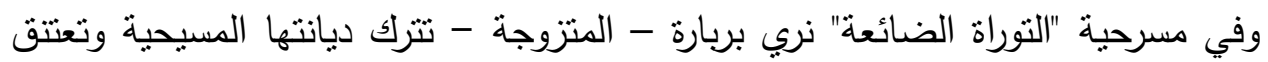

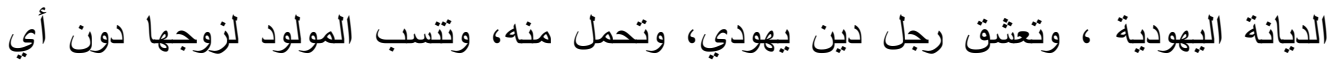

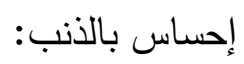

بربارة : فقد أسعدنتي تللك الليلة بعد انقطاع طويل. كوهين : صحيح؟ أنا لا أنذكر والله.

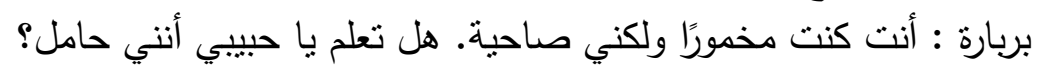

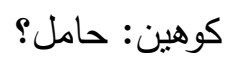
بربارة: من نلك الليلة! كوهين: (فرحًا) هذه معجزة. (Ir.)

- تعمل ضمن جماعات وظيفية:

في مسرحية شيلوك الجديد، يرسم لنا باكثير الدور الذي تلئي تلعبه الثخصيات اليهودية

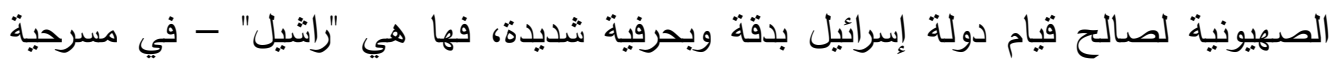

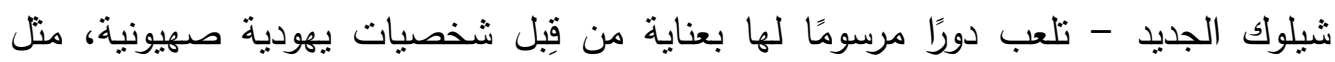

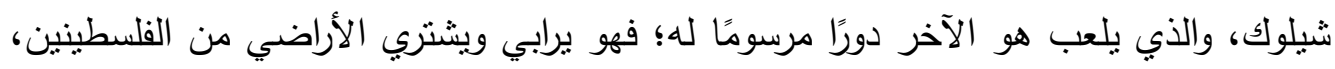

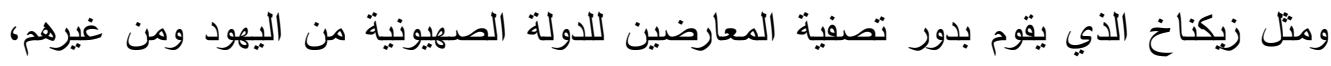

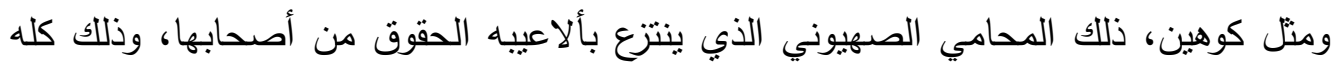

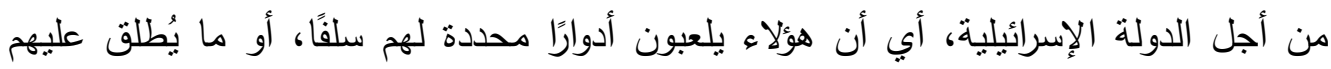
الجماعات الوظيفية.

ومصطلح الجماعات الوظيفية هو مصطلح يقصد به مجموعة من البشر تأني من خارج المجتم غالبأ، ومن داخله أحيانًا، وذلك بقصد القيام بوظائف وأعمال تخريبية ودموية وارتزاقية

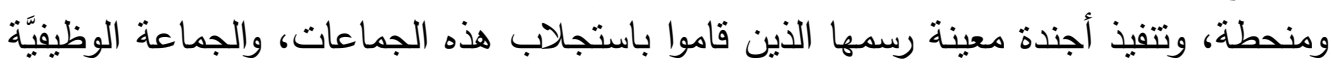

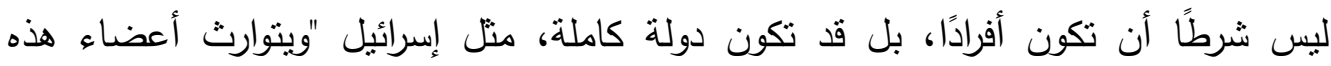

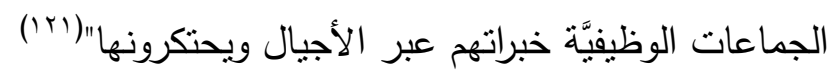

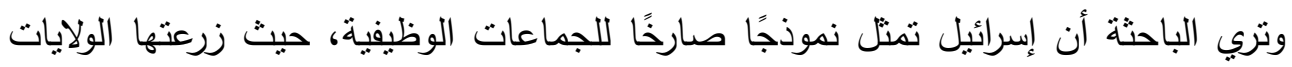

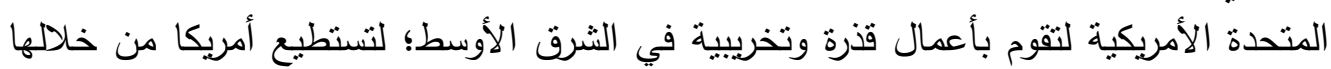

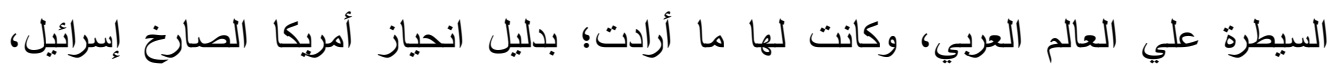

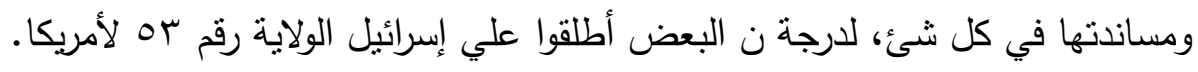

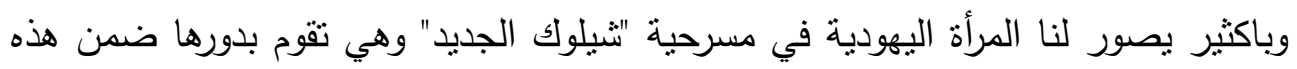

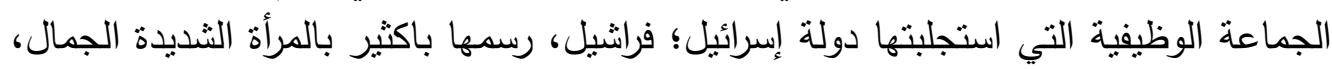

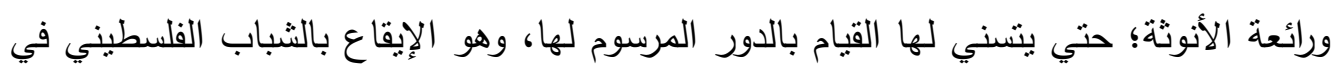

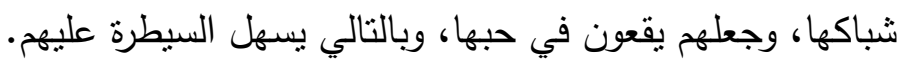


خليل : (...) لقد أديت واجبي الذي أقدر عليه. أما الباقي فعلي جمالك يا راشيل وفنتنك.

راشيل : قل هذا للمسيو شيلوك حين تقابله

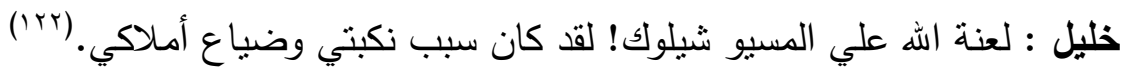

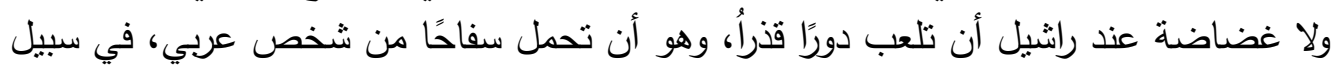

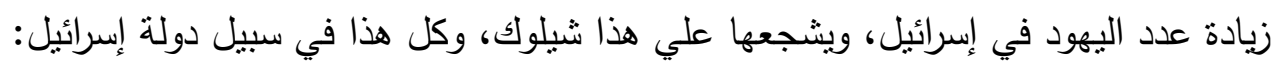

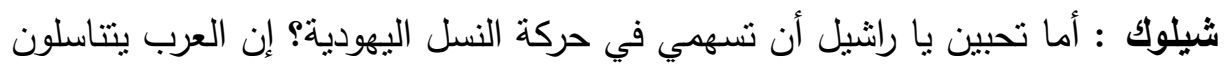

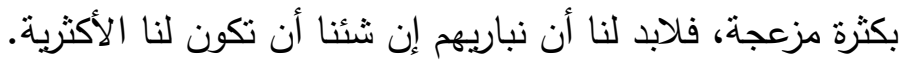

$$
\text { (...) }
$$

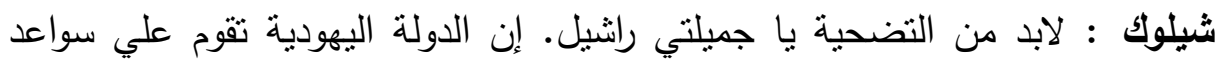

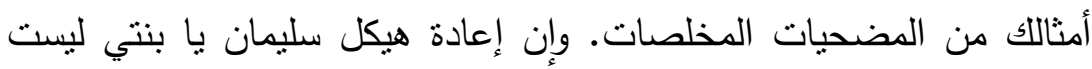

$$
\text { راشيل : كلا كلا، أقول للك. }
$$

شيلوك : (يمسك خديها بيديه ملاطفًا) حسنًا، لا تغضبي يا راثنيل ولا تحملي همًا.

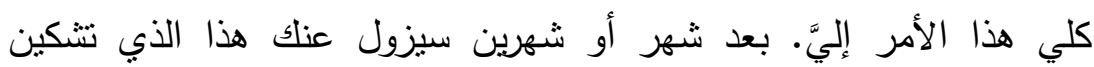

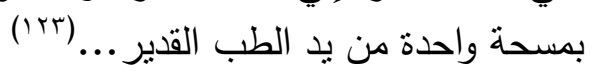

ولا تختلف شخصية راشيل في مسرحية شيلوك الجديد عن شخصية راشيل راشيل في مسرحية

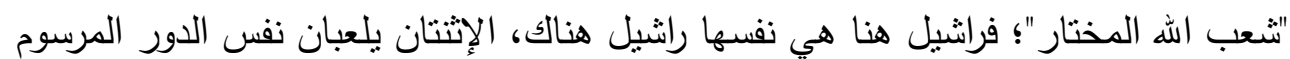

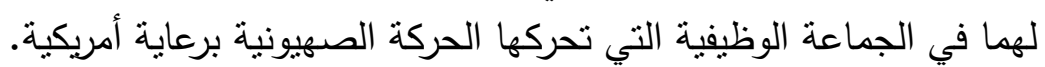

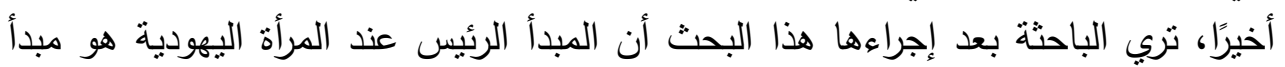

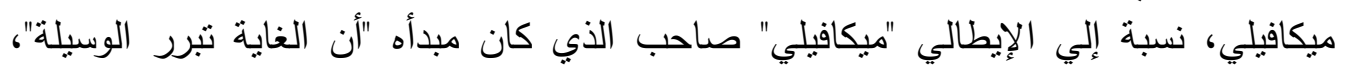

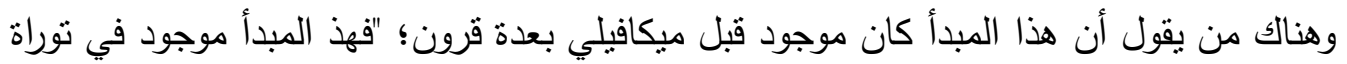

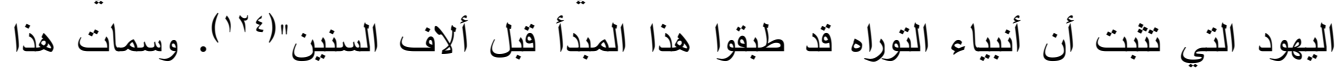

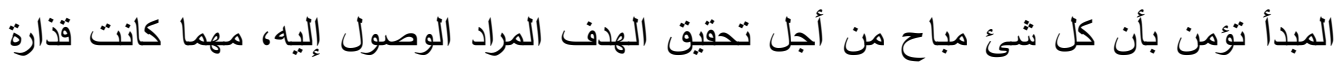

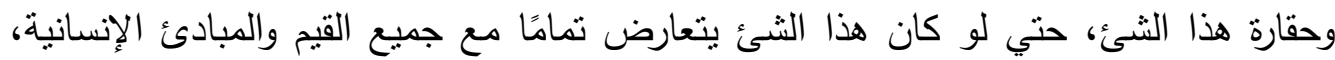

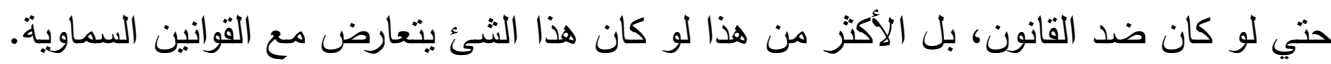

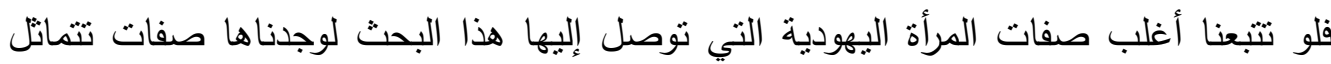

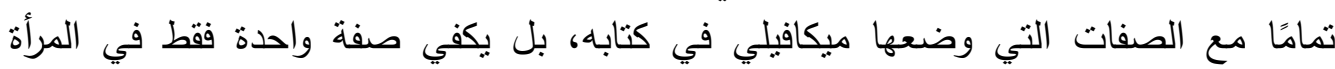
اليهودية ، وصفها بها علي أحمد باكثير في نصوصه عي عينة هذا البحث، للبرهنة علي أني أن المرأة

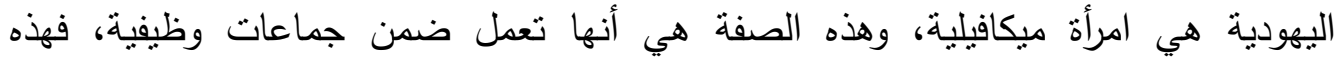
الجماعات كما أظهر هذا البحث مبدأها الرئيس هو الغاية تبرر الوسيلة، مهما كانت حرمانية

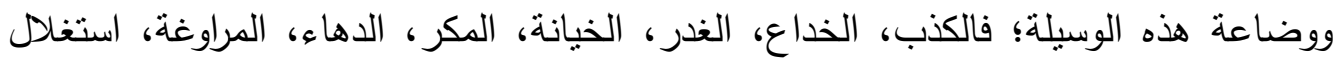


الآخر، التجارة بالدين والاستهانة به، .. إلخ، هي مبادئ ميكافيلية تؤمن بها الجماعات الجماعات الوظيفية.

\section{نتائج البحث}

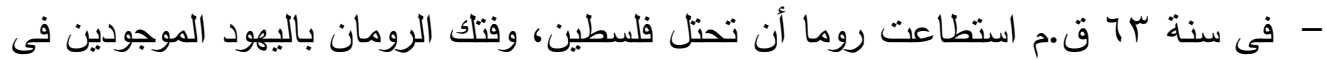

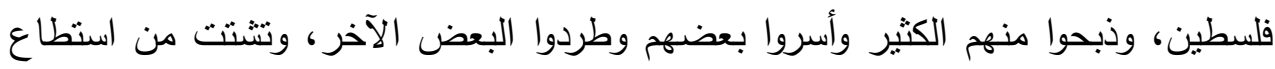

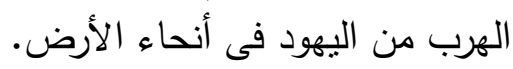

- عندما نزلت المسيحية اعتقها بعض اليهود اليهود، وأصبحت فلسطين دولة مسيحية بنهاية القرن

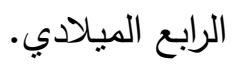

- اختلق اليهود مشاكل كثيرة في كل بلد عانشوا فيها، واتسم سلوكهم بالفساد والفسق والعداء

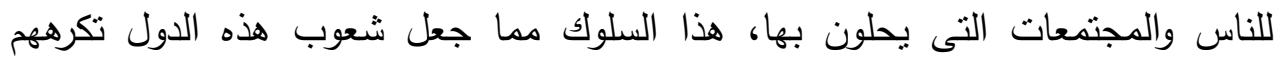
وتتبذهم وتكرههم. وكان الحل أن يعيشوا مع بعضهم البعض في مكان واحد بعيد عن كل

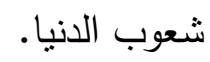

- قامت الدولة اليهودية على أنقاض شعب أخر وهو الثعب الفلسطينى. - ادعاء اليهود أنهم جنس سامي وأنهم من سلالة نقية الدعاء أنساء كاذب.

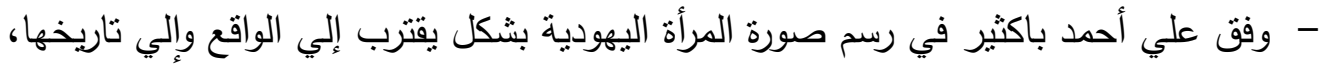

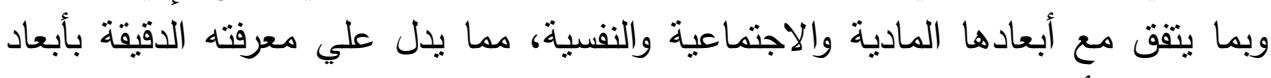
شخصية المرأة اليهودية. - المرأة اليهودية في مسرح باكثير جميلة الثكل، وتتمتع بالوجه الحسن والقوام الفتان. فهي امرأة شقراء ممشوقة القوام، ناضجة الأنوثة، كلها إغراء وفنتة.

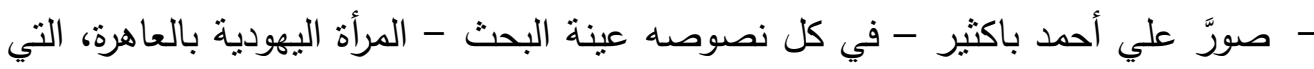
تعشق ممارسة الجنس دون تمييز ، بمقابل أحيانًا، وبدون مقابنة الحيل أحيانًا أخري. - المرأة اليهودية الإسرائيلية لا تتواني في ممارسة الجنس مع أي أشخاص في في سبيل تحقيق أندائ أهداف معينة لصالحها. - استخدام المرأة فى الجنس بغرض الوصول إلى أهداف ومكاسب معينة مباح عند بعض رجال الدين اليهودي. - المرأة اليهودية تمارس الرزيلة والعُهر تحت سمع وبصر أبويها وزوجها وأقربائها دون ممانعة منهم. - علي عكس الصورة التي أظهرها للمرأة اليهودية، أظهر علي أحمد باكثير المرأة العربية في

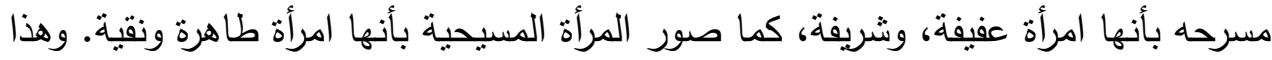
الأمر بطبيعة الحال ضد مبادئ العهر والابتذال التي تعتتقها المرأة اليهودية.

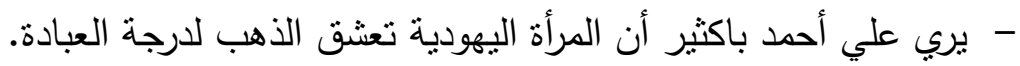


- الكذب سمة متأصلة في المرأة اليهودية، كما عكستها النصوص عينة البحث. - - عكست النصوص المسرحية عينة الدراسة أن الخيانة سمة متأصلة في المرأة اليهودية. - أظهر مسرح باكثير مدي إهمال المرأة اليهودية لأسرتها. - المرأة اليهودية في مسرح باكثير هي امرأة تتمتع بذكاء ودهاء كبير الهيرين.

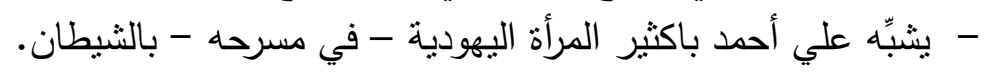

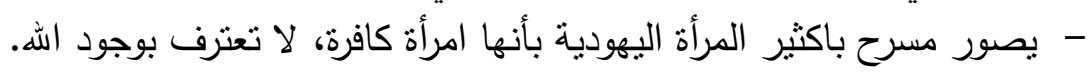
- وصف علي أحمد باكثير المرأة اليهودية بالمرأة الغيورة. - المرأة في مسرح باكثير إمرأة مخادعة ومحتالة. - صورَّ علي أحمد باكثير المرأة اليهودية في مسرحه بالمرأة عديمة الأخلاق.

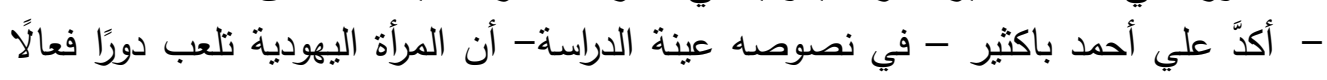
داخل الجماعات الوظيفية الإسرائيلية.

- لا تختلف شخصية راشيل في مسرحبة شيلوك الجديد عن شخصبة راشيل في مسرحية

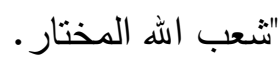




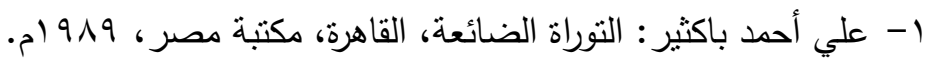

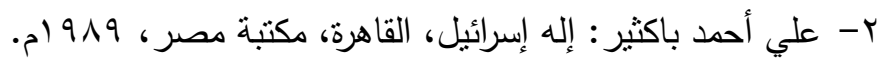

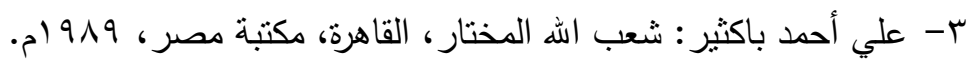

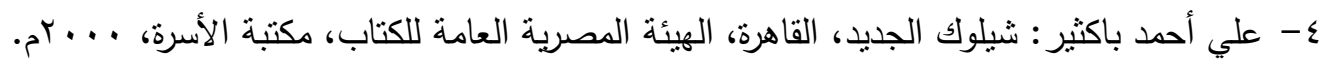

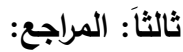

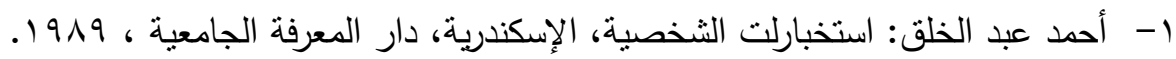

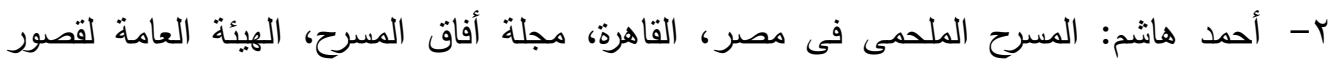

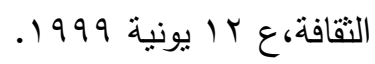

r- آرثر آسا بيرغر: وسائل الإعلام والمجتمع، ترجمة: صالح خليل أبو إصبع، الكويت، سلسلة عالم المعرفة.

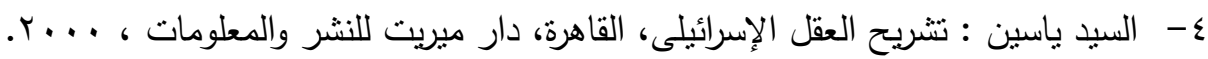

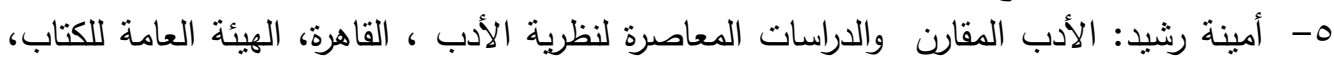

$$
. r \cdot 11
$$

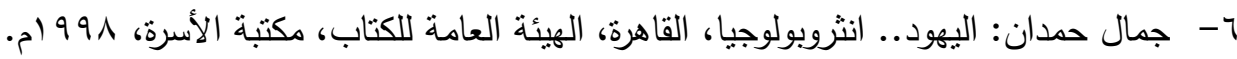

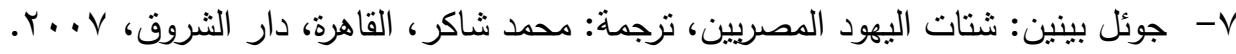

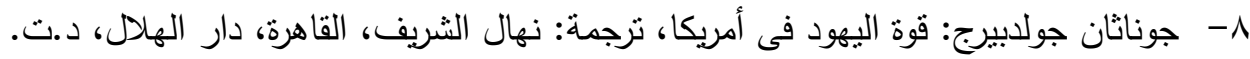

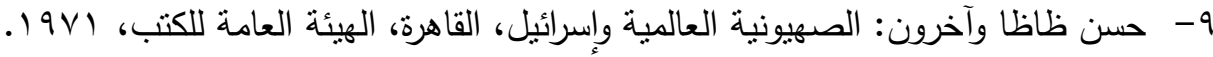

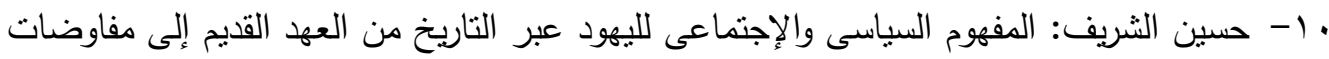

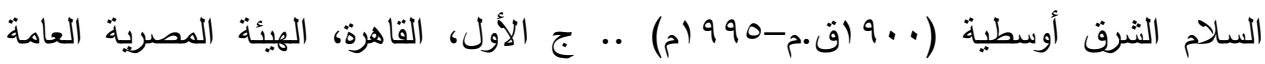

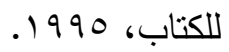

1) خالد جودة أحمد : الصهيونية فى أدب على أحمد باكثير ، القاهرة ، الهيئة المصرية العامة

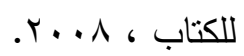

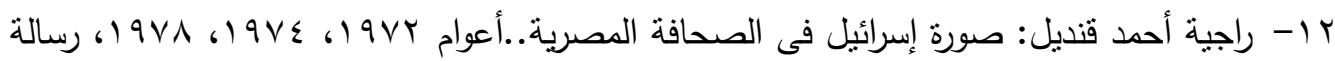

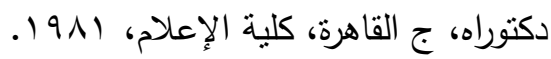

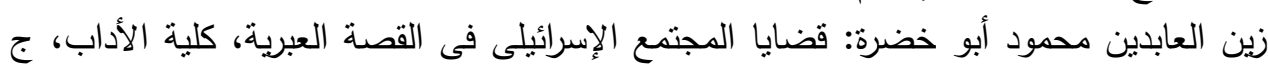

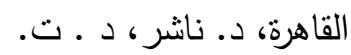

ع ا - سليم حسن: موسوعة مصر القديمة .. الجزء الخامس .. السيادة العالمية والتوحيد، القاهرة، مكتبة

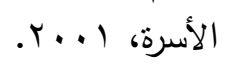

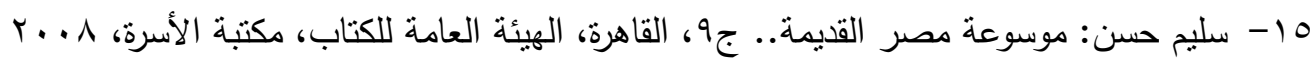

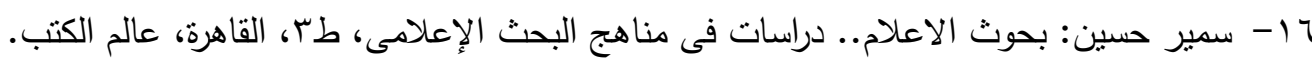


V ال سهام نصار: الصحافة الإسرائيلية والدعاية الصهيونية فى مصر، القاهرة، الزهراء للإعلام

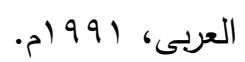

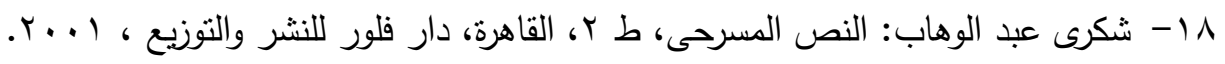

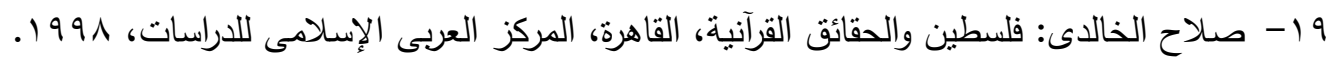

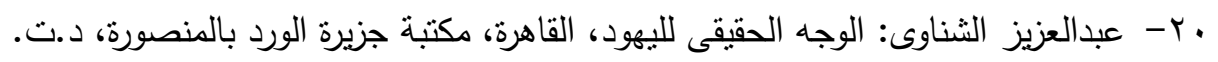

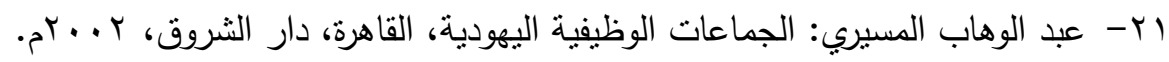

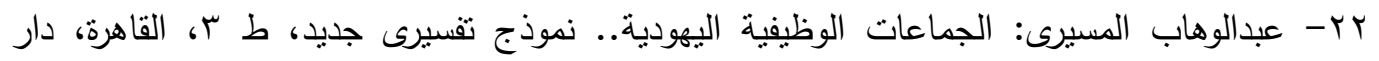

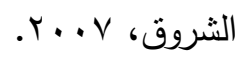

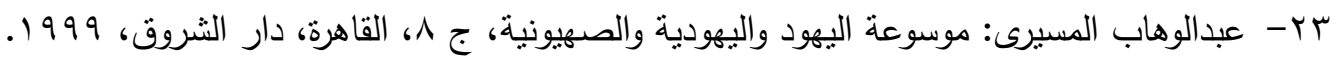

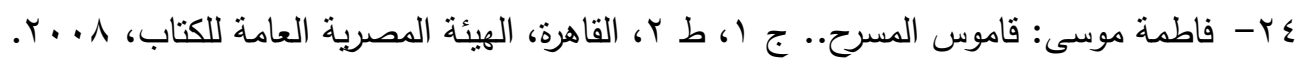
هץ- فرج عمر فرج: الشخصية اليهودية بين مسرح كريستوفر مارلوا ووليم شكسبير وبين المسرح

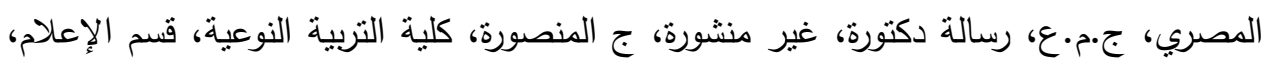
ف דr- فرج عمر فرج: العلاقة بين الحاكم والمحكوم في المسرح المصري، القاهرة، رسالة ماجسنير غير

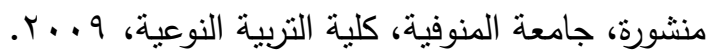
VY - مارى كارمن بوبيس: سيمولوجيا المسرح، ترجمة: أحمد عبدالعزيز، القاهرة، دار النصر للتهنة، التوزيع

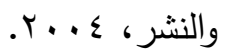

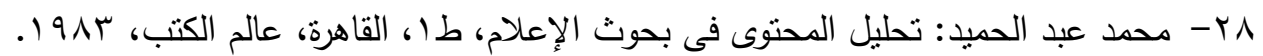

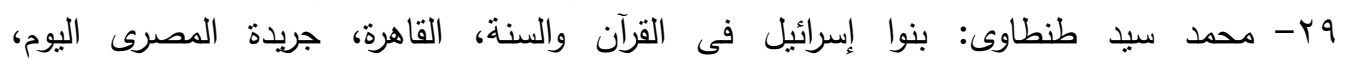

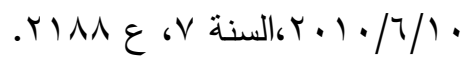
•r- مجدى البكرى: تاريخ الأديان السماوية، الدين اليهودى، ج الأول، القاهرة، مطابع اللوتس

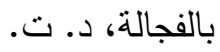

اس- مصرى عبدالحميد حنورة: الأسس النفسية للإبداع الفنى فى الشعر المسرحى، القاهرة، الهيئة

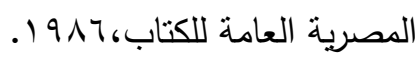

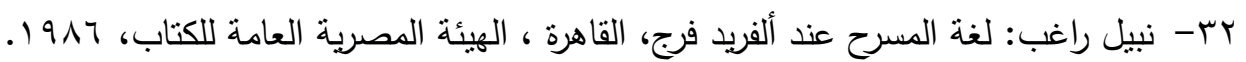
rr- لاجوس آجرى: فن كتابة المسرحية، ترجمة: درينى خثبة، الكويت، دار سعاد الصباح.

- صلاح الخالدى: فلسطين والحقائق القرآنية، القاهرة ، المركز العربى الإسلامى للاراسات، 9 (9 1، ص ט r - زين العابدين محمود أبو خضرة: قضايا المجتمع الإسرائيلى فى القصة العبرية، كلية الأداب، ج

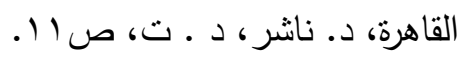


r - فرج عمر فرج: الثخصية اليهودية بين مسرح كريستوفر مارلوا ووليم شكسبير وبين المسرح المصري، ج•م•ع، رسالة دكتورة، غير منشورة، ج المنصورة، كلية التربية النوعية، قسم

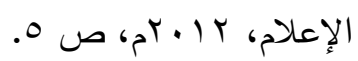

؛ - أحمد هاشم: المسرح الملحمى فى مصر، القاهرة، مجلة أفاق المسرح، الهيئة العامة لقصور

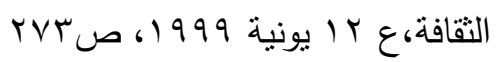

• - أمينة رشيد: الأدب المقارن والدراسات المعاصرة لنظرية الأدب ، القاهرة، الهيئة العامة للكتاب،

$$
.49 \text { ( }
$$

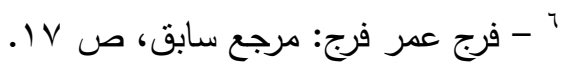

" - سمير حسين : بحوث الاعلام .. دراسات فى مناهج البحث الإعلامى ،طس ، القاهرة ، عالم

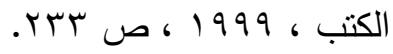

^ - محمد عبد الحميد : تحليل المحتوى فى بحوث الإعلام ، طا ، القاهرة ، عالم الكتب ، به9 19 ، ص ص

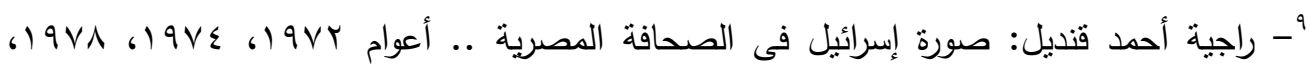

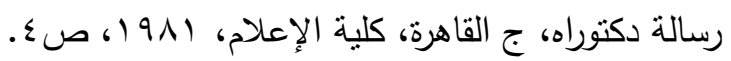

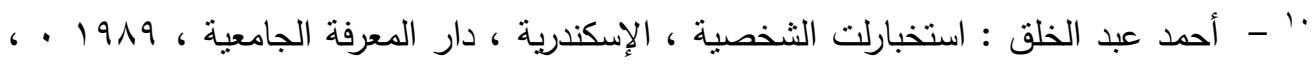

$$
\text { ص }
$$

'" - عبدالوهاب المسيرى: موسوعة اليهود واليهودية والصهيونية، ج ^ ، القاهرة ، دار الشروق ،

$$
\text { . } 2 \text { ص ص } 1999
$$

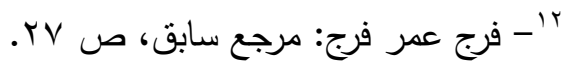

ז'- السيد ياسين : تشريح العقل الإسرائيلى ، القاهرة ، دار ميريت للنشر والمعلومات ، ، .. . . ،

$$
\text { ص }
$$

عا - جمال حمدان : اليهود .. انثروبولوجيا ، القاهرة ، الهيئة العامة للكتاب ، مكتبة الأسرة ،

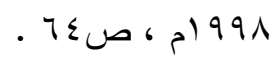

10- محمد سيد طنطاوى: بنوا إسرائيل فى القرآن والسنة، القاهرة، جريدة المصرى اليوم،

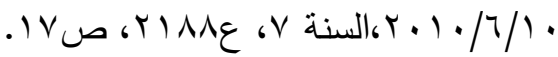

$$
\begin{aligned}
& \text { - - عبدالوهاب المسيرى : مرجع سابق ، ص. ص. ـ . }
\end{aligned}
$$

VIV- سليم حسن: موسوعة مصر القديمة .. الجزء الخامس .. السيادة العالمية والتوحيد، القاهرة،

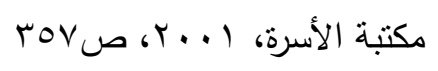


^1 - عبدالعزيز الثناوى: الوجه الحقيقى لليهود، القاهرة، ، مكتبة جزيرة الورد بالمنصورة ، د. ت، ص

9 1 - عبدالوهاب المسيرى: الجماعات الوظيفية اليهودية .. نموذج تفسيرى جديد ، ط ب ، القاهرة ، دار

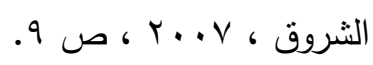

• - فرج عمر فرج: العلاقة بين الحاكم والمحكوم في المسرح المصري، القاهرة، رسالة ماجستير غير

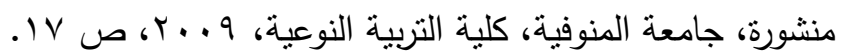

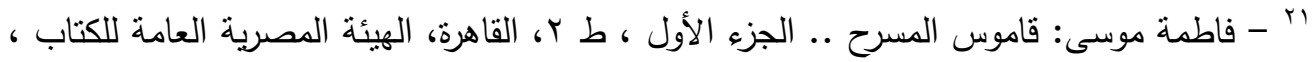

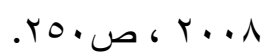

rr - خالا جودة أحمد : الصهيونية فى أدب على أحمد باكثير ، القاهرة ، الهيئة المصرية العامة

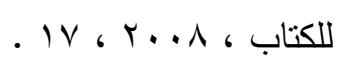

rז'- سهام نصار: الصحافة الإسرائيلية والدعاية الصهيونية فى مصر ، القاهرة ، الزهراء للإعلام

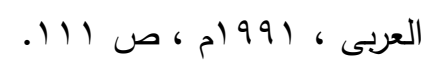

ءr - فرج عمر فرج: الثخصية اليهودية بين مسرح كريستوفر مارلو ووليم شكسبير وبين المسرح

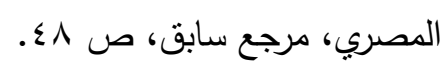

مr - فرج عمر فرج: الشخصية اليهودية بين مسرح كريستوفر مارلو ووليم شكسبير وبين المسرح

$$
\begin{aligned}
& \text { المصري، مرجع سابق ، ص } 10 .
\end{aligned}
$$

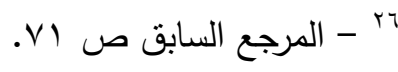

Yr - - حسين الثريف: المفهوم السياسى والإجتماعى لليهود عبر التاريخ من العهد القيم إلى مفاوضات السلام الثرق أوسطية ( . .9 (ق.م-900 (م) .. ج الأول، القاهرة، الهيئة المصرية

$$
\text { العامة للكتاب، } 990 \text { 1، ص. •r. }
$$

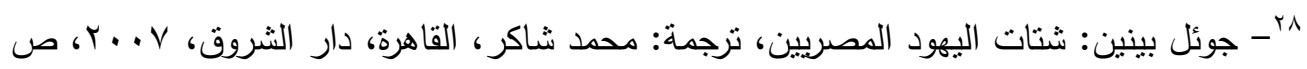

9ז' - مجدى البكرى: تاريخ الأديان السماوية، الدين اليهودى، ج الأول، القاهرة ، مطابع اللوتس د.

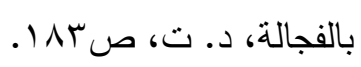

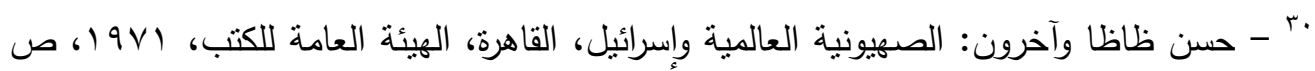

$$
.1 \leq 0-1 \leq \leqslant ص
$$

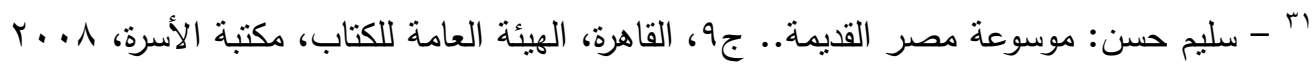


rr - لاجوس آجرى: فن كتابة المسرحية، ترجمة: درينى خشبة، الكويت، دار سعاد الصباح، صعء ـ .

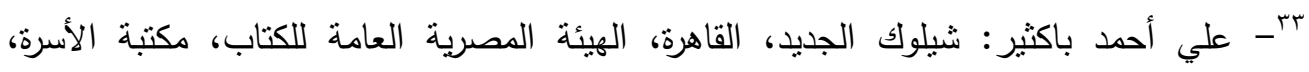

$$
\begin{aligned}
& \text { י... }
\end{aligned}
$$

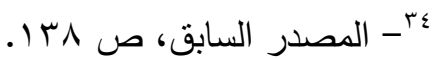

مr - جوناثان جولدبيرج: قوة اليهود فى أمريكا، ترجمة: نهال الثريف، القاهرة، دار الهلال، د ـ.ت، ت

$$
\text { ص ص }
$$

بr - آرثز آسا بيرغر: وسائل الإعلام والمجتمع، ترجمة: صالح خليل أبو إصبع، الكويت، سلسلة

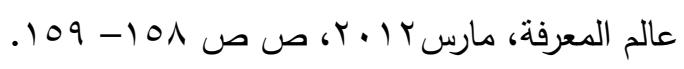

Vrr- مصرى عبدالحميد حنورة: الأسس النفية للإبداع الفنى فى الثعر المسرحى، القاهرة، الهيئة

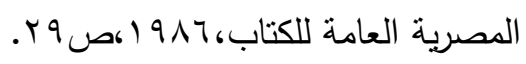

^r - نبيل راغب: لغة المسرح عند ألفربد فرج، القاهرة ، الهيئة المصرية العامة للكتاب، $9 \wedge 1$ (، ص

$$
.107
$$

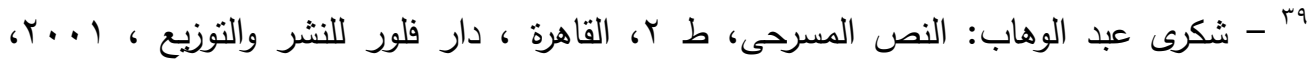

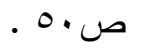

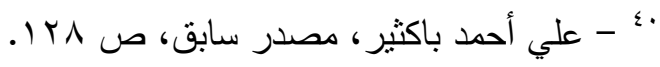

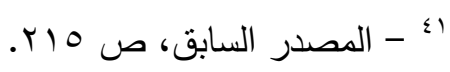

r r

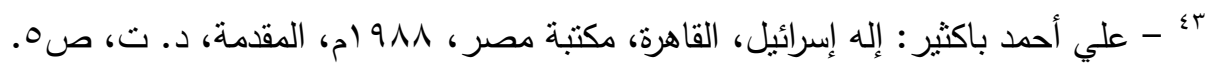

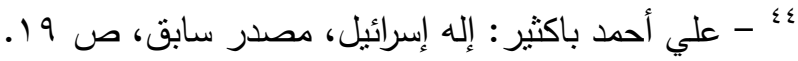

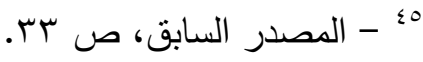

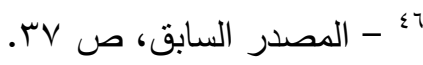

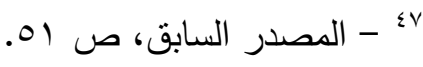

$$
\begin{aligned}
& \text { هـ - المصدر السابق، ص OV }
\end{aligned}
$$

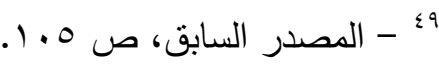

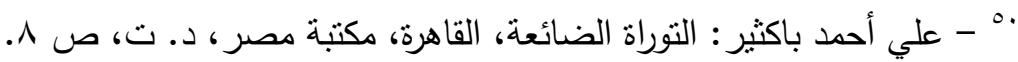

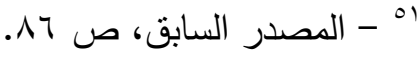

$$
\begin{aligned}
& \text { or } \\
& \text { or } \\
& \text { \&0 - المصدر السابق، ص } 90
\end{aligned}
$$

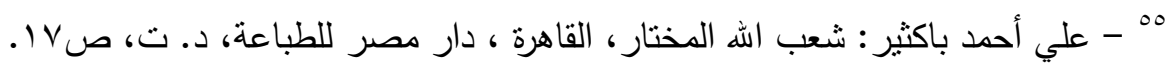


ror الم

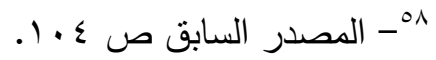

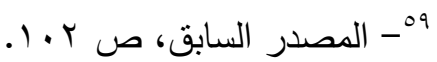
"ج - مارى كارمن بوبيس: سيمولوجيا المسرح، نرجمة: أحمد عبدالعزيز، القاهرة، دار النصر للتوزيع

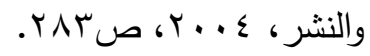

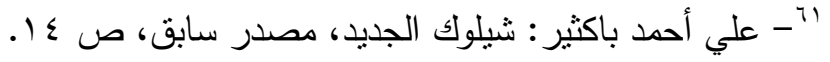

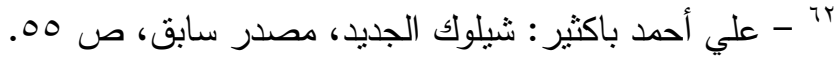
"آ - فرج عمر فرج: الثخصية اليهودية بين مسرح كريستوفر مارلو صائو ووليم شكسبير وبين المسرح

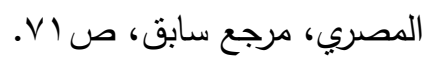

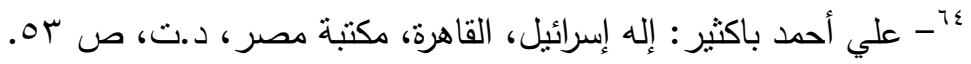

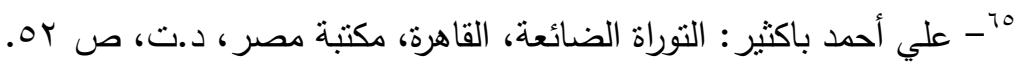

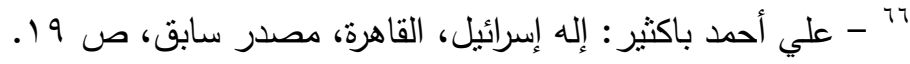

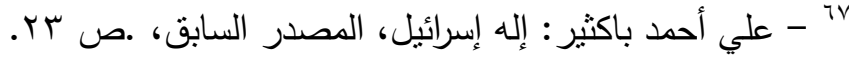

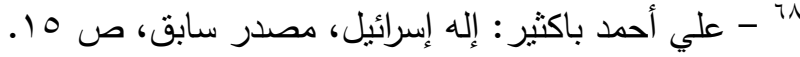

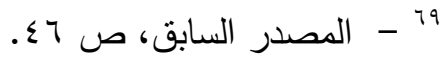

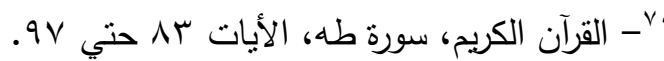
rr

$$
\text { r }
$$

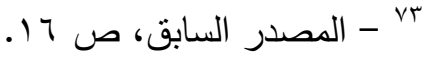

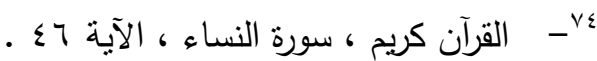

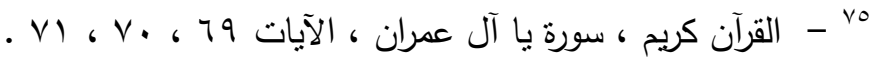

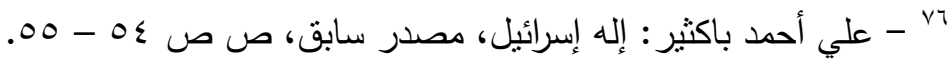

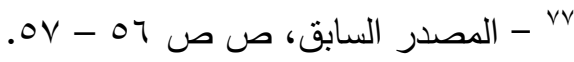

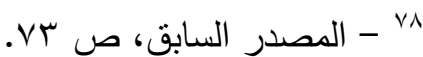

Pla

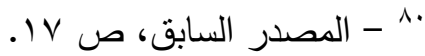

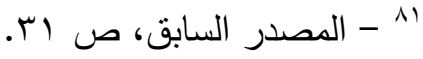
ا r

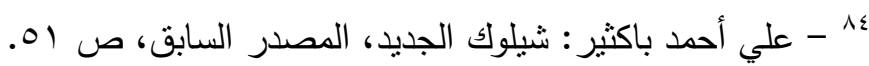

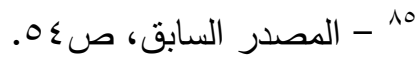


ז^ - فرج عمر فرج: الثخصية اليهودية بين مسرح كريستوفر مارلو ووليم شكسبير وبين المسرح

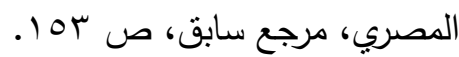

NV

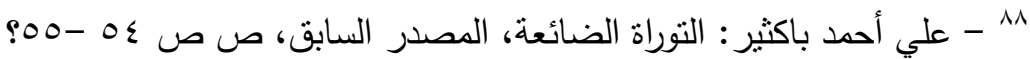

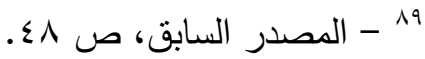

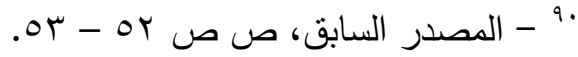

I

r

r

פو

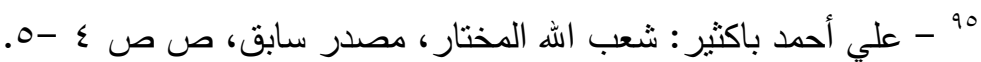

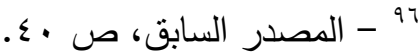

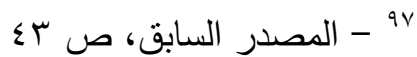

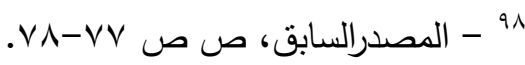

99

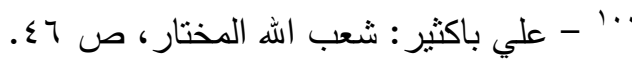

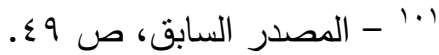

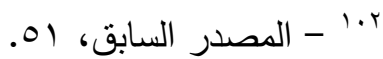

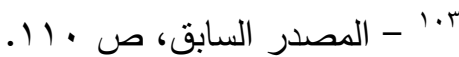

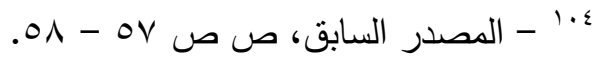

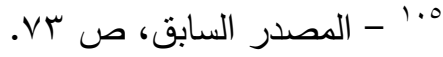

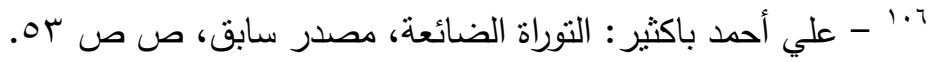

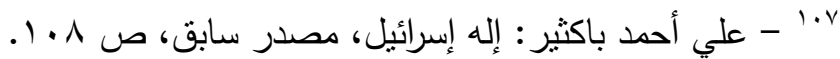

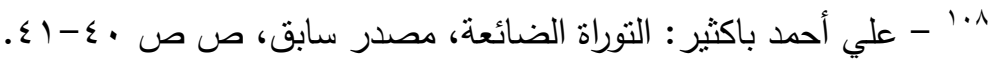

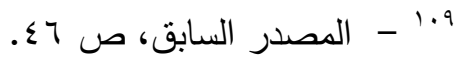

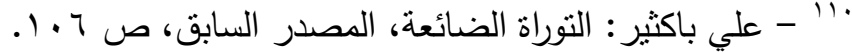

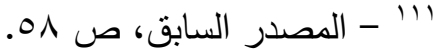

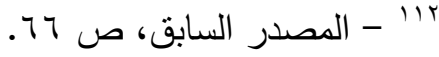

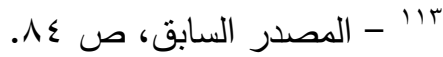

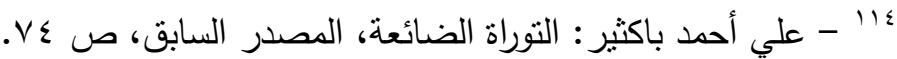

9 110

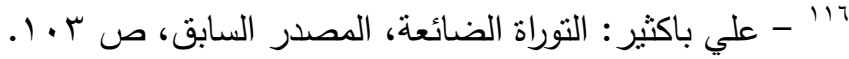




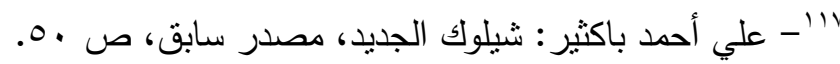

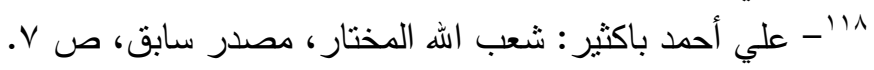

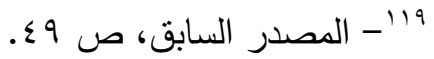
•r.

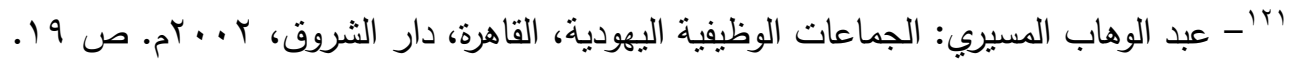

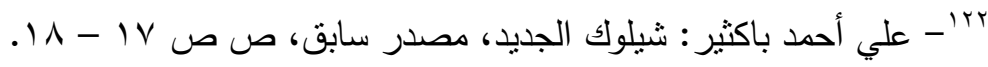
(rr

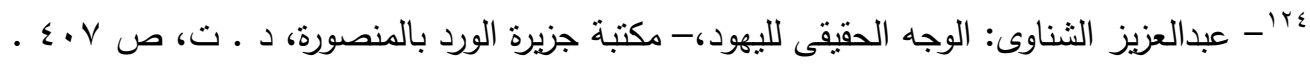

